\title{
From turnpikes to railroads: Antebellum transportation improvements and community development in Taylor County, Virginia
}

\author{
Scott W. Daley \\ West Virginia University
}

Follow this and additional works at: https://researchrepository.wvu.edu/etd

Part of the History Commons

\footnotetext{
Recommended Citation

Daley, Scott W., "From turnpikes to railroads: Antebellum transportation improvements and community development in Taylor County, Virginia" (1999). Graduate Theses, Dissertations, and Problem Reports. 3952.

https://researchrepository.wvu.edu/etd/3952

This Thesis is protected by copyright and/or related rights. It has been brought to you by the The Research Repository @ WVU with permission from the rights-holder(s). You are free to use this Thesis in any way that is permitted by the copyright and related rights legislation that applies to your use. For other uses you must obtain permission from the rights-holder(s) directly, unless additional rights are indicated by a Creative Commons license in the record and/ or on the work itself. This Thesis has been accepted for inclusion in WVU Graduate Theses, Dissertations, and Problem Reports collection by an authorized administrator of The Research Repository @ WVU. For more information, please contact researchrepository@mail.wvu.edu.
} 


\title{
FROM TURNPIKES TO RAILROADS:
}

Antebellum Transportation Improvements and Community Development in Taylor County, Virginia

by

Scott W. Daley

\author{
Thesis submitted to the \\ College of Arts and Sciences \\ at West Virginia University \\ in partial fulfillment of the requirements \\ for the degree of
}

\section{Master of Arts}

in

History

\author{
A. Michal McMahon, Ph.D., Chair \\ Barbara J. Howe, Ph.D. \\ Lawrence T. Nichols, Ph.D. \\ Department of History
}

Morgantown, West Virginia

1999

Keywords: Railroads, Turnpikes, Fetterman, Pruntytown, Grafton, Taylor County, Virginia

Copyright 1999 Scott W. Daley 
UMI Number: 1402827

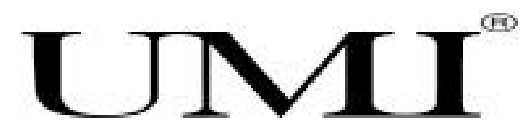

UMI Microform 1402827

Copyright 2000 by Bell \& Howell Information and Learning Company. All rights reserved. This microform edition is protected against unauthorized copying under Title 17, United States Code.

Bell \& Howell Information and Learning Company 300 North Zeeb Road

P.O. Box 1346

Ann Arbor, MI 48106-1346 


\begin{abstract}
FROM TURNPIKES TO RAILROADS:

Antebellum Transportation Improvements and Community Development

in Taylor County, Virginia
\end{abstract}

Scott W. Daley

In the 1820s, a revolution in transportation technology changed forever the shipment of goods, travel, and the process of communication as overland transportation shifted from turnpikes to railroads. This study examines the affect on community formation and development in two turnpike villages and one town along the Baltimore \& Ohio Railroad, America's first inter-regional commercial railroad line. Between the mid-1830s and 1860, as railroads replaced turnpikes, the villages of Fetterman and Pruntytown, Virginia, came into existence, flourished, and began to decline as railroads passed along the lower Tygart River in 1850, directly competing with turnpikes. The town of Grafton in Taylor County, Virginia, built for the railroad, began in 1850, and was large enough for incorporation by 1856. Emerging railroad technology would make turnpikes obsolete and draw Taylor County, along with much of northern Virginia, into a national transportation system, reducing the isolation of many small communities.

The Baltimore \& Ohio Railroad represented a new technology that shaped communities. Cities, towns, and villages not directly along the railroad began to fall into disuse. Grafton received a further boost in 1856 when it served as the junction point for the Northwestern Virginia Railroad, which connected the Ohio River valley to the Baltimore \& Ohio Railroad.

This thesis examines the earliest industrialization of the lower Tygart River valley brought about by railroads. In the 1850 s, choices over transportation modes and alignments helped form the town of Grafton and contributed to commercial and community development in Taylor County. In Taylor County, a new form of community came into existence: a railroad town which assumed characteristics of eastern cities, and provided a prototype for railroad towns of the west during postCivil War expansion. Although still agricultural in 1860, the seeds of industrialization had been sown in Taylor County with the convergence of two railroads which introduced modernized transportation. 


\section{ACKNOWLEDGMENTS}

I am deeply indebted to a number of people who assisted in producing this work. The staff and archivists at the West Virginia and Regional History Collection at the West Virginia University Libraries provided a tremendous amount of help, not only in supplying archival materials, but in providing leads to locating some rather obscure sources. Nancy Virginia Fowler and her staff at the Taylor County, West Virginia, County Clerk's Office in Grafton extended patient guidance in negotiating county records. I am also grateful to Ann Calhoun at the Baltimore \& Ohio Railroad Museum, Hays T. Watkins Research Library in Baltimore, Maryland. Special thanks to Emory L. Kemp, Michael Caplinger, and the staff of the Institute for the History of Technology and Industrial Archaeology at the West Virginia University for their advice and inspiration for this project.

Lawrence T. Nichols, professor of Sociology and Anthropology, graciously filled a vacancy on my graduate committee, and brought an important depth of knowledge that informed my work. Barbara J. Howe afforded order and a framework previously lacking in this project, and helped me to place a local history into a national context. My advisor, A. Michal McMahon, reviewed innumerable drafts of this project, offering advice, guidance, and moral support, even during the most trying times. The criticism, academic rigor, and help of my graduate committee is greatly appreciated.

I wish to thank my parents, William and Barbara, for their unending support. And last, but far from least, I thank my wife Amy, who never wavered from her faith in my work, nor from her support, understanding, and encouragement while attending to our lives. 
CONTENTS

Introduction

Chapter 1: Broaching the Wilderness

9

Influx

12

The Issue Was Good Roads 19

Turnpike 21

Transition $\quad 29$

Chapter 2: Politics and Iron Horses 36

Making Tracks $\quad 38$

The Northwestern Virginia Railroad 62

Recompense $\quad 68$

$\begin{array}{ll}\text { Juncture } & 71\end{array}$

$\begin{array}{ll}\text { Elbowroom } & 72\end{array}$

$\begin{array}{lr}\text { Chapter 3: Railroad Town } & 80\end{array}$

Grafton $\quad 83$

The Tie That Binds $\quad 88$

Riding The Rails $\quad 97$

$\begin{array}{lr}\text { Conclusion } & 105\end{array}$

$\begin{array}{ll}\text { Bibliography } & 111\end{array}$

$\begin{array}{ll}\text { Appendix } & 124\end{array}$ 


\section{ABBREVIATIONS}

B\&O- Baltimore \& Ohio Railroad

BORR- Baltimore \& Ohio Railroad as used in reference to its annual reports

BPW- Virginia Board of Public Works

NVRR- Northwestern Virginia Railroad

TCCC- Taylor County Clerk of Courts Office

WVDAH- West Virginia Division of Archives and History, Charleston, West Virginia

WVRHC- West Virginia Regional and History Collection, Morgantown, West Virginia 


\section{Introduction}

In these central solitudes every thing seems to be the property of the wilderness. It is all absolute mountain, absolute forest, absolute solitude. But in Tygart's Valley the landscape softens and becomes more human, with the marks of agriculture and habitation, and the road seems to bound along more gayly, as if exulting in its release from the mountains. ${ }^{1}$

This is a story about the transformation of a region through successive transportation improvements. In nineteenth century western Virginia, mountainous terrain isolated the population, and the region's economy rarely kept pace with that of the nation. The land yielded natural resources for national consumption, but even as designs developed over time to extract them, little profit returned to the region. In the case of antebellum Virginia, eastern Virginians profited from western trade, while most westerners could barely make a living. ${ }^{2}$ The predominant problem was the poor quality of transportation. Effective transportation systems within the Allegheny Mountains came at great expense, and often fell well short of plans and expectations.

Grafton, Virginia, in Taylor County, a town built for the Baltimore \& Ohio (B\&O) Railroad, represented both a typical and distinctive example of how railroads and industrialization changed the roles of community and commerce in America. The railroad furnished a compelling force for community growth, causing Grafton to look very much like most railroad towns of the antebellum period. But Grafton attained a high level of success as a community due to its position at a vital rail 10.

${ }^{1}$ Brantz Mayer, “A June Jaunt,” Harper's New Monthly Magazine 14 (June 1857): 609-

${ }^{2}$ For an examination of transportation and commercial development in Appalachian America, see Wilma A. Dunaway, The First American Frontier: Transition to Capitalism in Southern Appalachia, 1700-1860 (Chapel Hill: University of North Carolina Press, 1996), 13652; Robert D. Mitchell, Commercialism and Frontier: Perspectives on the Early Shenandoah Valley. (Charlottesville: University Press of Virginia, 1977), 8-18, 179-86, 261-83. 
junction between the $\mathrm{B} \& \mathrm{O}$ and Northwestern Virginia (NVRR) railroads, attracting people who established lumber processing mills, glass manufacturing plants, and additional rail lines to the town during the last half of the nineteenth century. ${ }^{3}$ Indeed, Grafton is still an active railroad town at a time when few original railroad towns have survived the decline in rail transport.

Most Americans in the early nineteenth century recognized improved transportation as necessary for communication and prosperity, and a number of plans evolved employing turnpikes, canals, and railroads. Yet, regardless of the mode under consideration, the same issues arose. Each project involved land acquisition for construction and political maneuvering to obtain company charters. Determining destinations and way stations also, occasionally, brought about political and financial coalitions, as well as some subterfuge.

Transportation developments lay at the heart of economic progress, both at the local and national levels. With an eye toward claiming western resources, commercial competition among east coast cities strongly influenced the nation's economy as early as colonial times. By the mid-1800s, the major American seaport cities of Boston, New York, Philadelphia, Baltimore, Norfolk, Virginia, and Charleston, South Carolina, vied to dominate the trade routes to and from the continent's interior which would complement and supply their respective international trade routes.

Commerce from Virginia's western mountains bound for Norfolk, for example, first moved over trails made by Native Americans. In the early nineteenth century, settlers employed those paths as roads, driving hogs, wagon loads of pelts, and unrefined iron eastward to market, returning with what few essential manufactured goods they could carry. These routes were generally of wretched

\footnotetext{
${ }^{3}$ Ronald L. Lewis, Transforming the Appalachian Countryside: Railroads, Deforestation, and Social Change in West Virginia, 1880-1920 (Chapel Hill: The University of North Carolina Press, 1998), 52-3, 67.
} 
quality. Poor roads severely limited the number of eastern homesteaders who would undertake entering the region, thereby keeping the western mountains comparatively isolated within forbidding topography until after the Civil War. ${ }^{4}$

Few private investors, committed groups, or governments could carry the financial burden for transportation improvements. But by 1816, Virginia's legislators had devised a plan to link the state's mountainous western regions to the port of Norfolk and capital at Richmond, using roads and canals. In a novel approach to the financing, Virginia became the first and only state of the time to apply a principle called "mixed enterprise." Mixed enterprise —usually a commercial arrangement that incorporated public and private initiative-paid for transportation improvements which, with luck, even provided sizeable profits. ${ }^{5}$

The Virginia Board of Public Works, the state's commission overseeing transportation improvements, planned four major east-to-west turnpikes to carry traffic to Richmond from all parts of the state. Northwestern Virginians used the Northwestern Turnpike. ${ }^{6}$ Most of the earliest towns in then eastern Harrison and southern Monongalia counties lay along its path, including Pruntytown and Fetterman. The founders of both towns took advantage of favorable topography, natural resources, and transportation improvements. The turnpike provided an easy route for travelers and migrants who tended to settle at crossroads and commercial interchanges. Pruntytown lay at the junction of the Booths Ferry Road and the Northwestern Turnpike, and Fetterman at the turnpike

\footnotetext{
${ }^{4}$ For an examination of the earliest migrations along northwestern Virginia's roadways, see Archer B. Hulbert, Historic Highways of America, volume 1 (Cleveland, Ohio: The Arthur H. Clark Company, 1902), 21-2, 138-9.

${ }^{5}$ For a more complete examination of Virginia's early turnpikes, see Robert F. Hunter, “The Turnpike Movement in Virginia, 1816-1860" (Ph.D. dissertation, Columbia University, 1957), 1-31.

${ }^{6}$ Ibid, 1.
} 
crossing of the Tygart River, itself a minor local commercial route. These places facilitated communication and commercial ties with eastern markets.

On the Atlantic coast, merchants and investors at Baltimore saw Norfolk's harbor as competition, but the cities most threatening Baltimore's success as a major ocean port and conduit to the nation's interior were New York and Philadelphia. New York investors had financed the Erie Canal between the Hudson River and Lake Erie by 1825, requiring eight years to build and throwing down a gauntlet for competitors. ${ }^{7}$ Philadelphia businessmen accepted the challenge by financing a series of canals and horse-drawn railroads in southeastern Pennsylvania during the same period. The Pennsylvania legislature launched its first effort in 1826 to connect Philadelphia and Pittsburgh with the State Road of Public Works, which became the Pennsylvania Railroad in $1846 .{ }^{8}$ From its inception, the Pennsylvania Railroad became an arch rival to the Baltimore \& Ohio Company. Both sought to control commerce in the Ohio River valley and beyond, and the two main lines of operation were never more than about 100 miles apart.

In Baltimore, a group of businessmen met at a private home in the winter of 1826 to consider transportation options. After months of lengthy and sometimes heated discussions, they decided that Baltimore would take the lead in what they had long sought by financing an extensive road of iron rails through the Allegheny Mountains to the inland waterways of the Ohio and Mississippi river

${ }^{7}$ For an examination of competition, canal boosters, and arguments over internal improvements, see Carol Sheriff, The Artificial River: The Erie Canal and the Paradox of Progress, 1817-1862 (New York: Hill and Wang, 1996), 9-22, 32-55, 110-37.

8 Timothy Jacobs, The History of the Pennsylvania Railroad (New York: Smithmark Publishing, 1988, 1996), 9-25. 
valleys. $^{9}$

Seeking a route along the shortest possible line, $\mathrm{B} \& \mathrm{O}$ planners preferred to meet the Ohio River headwaters at Pittsburgh, or at the highest point of year-round navigation at Parkersburg, Virginia. ${ }^{10}$ At the state and national levels, the designs and desires of Maryland's, Pennsylvania's, and Virginia's political leaders occasionally conflicted, and required accommodation in B\&O plans, leading to lengthy disagreements over its western terminus. $\mathrm{B} \& \mathrm{O}$ administrators further preferred building to Pittsburgh throughout the antebellum period in order to pull commerce away from the Pennsylvania Railroad. Parkersburg was their second choice as they could then control the lower Ohio River valley. Ultimately, the Virginia legislature forced the $\mathrm{B} \& \mathrm{O}$ to build to Wheeling, Virginia, and Thomas S. Haymond, a Marion County, Virginia, representative to the state House of Delegates, included a requirement for the $\mathrm{B} \& \mathrm{O}$ to build to the Tygart River and Three Forks Creek confluence in 1847 . When the B\&O railroad arrived there in 1851 , the town of Grafton came into existence, receiving its state charter five years later.

In the process of extending a system of railroads into Virginia's northwestern mountains, there were winners and losers: those who realized personal plans and others whose hopes for growth were dashed. Some people saw an improved life through railroads, and others lost out when they failed to embrace the new transportation technology. Connection to a market economy, a goal most western Virginians sought, broadened potential profits for people along the rail route. Indeed, capitalism, or at least a market economy, was the predominant goal not only for city-dwellers and

9 James D. Dilts, The Great Road: The Building of the Baltimore and Ohio, The Nation's First Railroad, 1828-1853 (Stanford: Stanford University Press, 1993), 13-24; John F. Stover, History of the Baltimore and Ohio Railroad (West Lafayette, Ind.: Purdue University Press, 1987), 4-14.

${ }^{10}$ Dilts, The Great Road, 36-48. 
townsfolk, but for people who left those places to populate the opening western frontiers. Even success for investors and boosters tended to be precarious because of the slim profit margins realized from transportation projects in the Allegheny Mountains. Building and operating transportation lines in the mountains tended to be expensive both in manpower and treasure, and failures became commonplace in the nineteenth century.

Because of the terrain, the lower Tygart River valley remained secluded before railroads arrived, even as settlement had moved to the Ohio River and beyond to the central plains. It was the region's isolation in mountainous northwestern Virginia that retarded commercial development. Living in a railroad town after 1851 , Grafton residents experienced multiple advantages of place, which made success an easier proposition. At the convergence of the Baltimore \& Ohio and Northwestern Virginia railroads, the Tygart River, and the Northwestern Turnpike, Grafton became a transportation hub with appreciably more commercial traffic and influx of travelers than seen in an average town. Technology, topography, and mid-nineteenth century politics dictated the place where Grafton evolved, and a market economy grew at a pace that would not have existed except for the railroad.

During the second half of the nineteenth century, as railroads expanded operations to connect with the Pacific coast, industrial needs led to communities like Grafton where light population and spotty agriculture gave way to steam power and industrial communities. Grafton proved to be an early archetype for communities built as the railroad carried settlers across the country after the Civil War. ${ }^{11}$ Technological innovations in transportation wrought by people in Britain and America's east

\footnotetext{
${ }^{11}$ For an examination of post-Civil War railroad communities, see John C. Hudson, Plains Country Towns (Minneapolis: University of Minnesota Press, 1985), 71-103.
} 
coast cities made an important contribution to an evolution in community and social structure.

Grafton was a significant railroad town through the early twentieth century, but no comprehensive history exists examining its formation. A literature search revealed works by Florence J. Adams and the Taylor County Historical and Genealogical Society, as well as narrative compilations of local personalities and events by Charles Brinkman. The Biographical and Portrait Cyclopedia of Monongalia, Marion and Taylor Counties, West Virginia, published in 1895, also supplied insight into several key people during Taylor County's development. Surviving newspapers described some of the early events and people of Grafton as well. Although these sources provided a base of facts, developing an understanding of events in the mid-1800s when transportation improvements led to the formation of Taylor County and Grafton required additional information.

The small amount of public and published records of Grafton's early history presents a challenge to its historians. In 1940, hundreds of city, county, and personal records were lost in a fire at Brinkman's opera house. In writing a modern history of Grafton, Charles Brinkman had gathered a wide range of information, but was unable to complete his task due to the tragic loss of resources. As such, the surest reliable sources for the earliest periods can be found in such places as Baltimore \& Ohio Railroad and Northwestern Turnpike records, as well as local histories. However, as a further complication, a major fire claiming over 1,000 structures in Baltimore's central business district on 7 and 8 February 1904 destroyed the B\&O headquarters building, with the loss of volumes of company records. ${ }^{12}$ Indeed, extant government or corporate records offer only supplements to written histories and cannot tell the whole story.

Yet these sources allow an examination of how railroads affected the quality of life in

${ }^{12}$ Stover, History of the Baltimore and Ohio Railroad, 200-1. 
northwestern Virginia in the mid-nineteenth century. Transportation improvements materially contributed to an expansion of social and commercial opportunities for people with ready access. In Taylor County, Virginia, the Northwestern Turnpike alleviated isolation and contributed to commerce to a modest degree during the 1830s and 1840s. But during the 1850s, the Baltimore \& Ohio and Northwestern Virginia railroads converted a sparsely populated, forested locale into a community reliant on industry and advanced transportation technology. Settlement and development patterns seen in Grafton during the 1850s characterized much of America between the midnineteenth and early twentieth centuries where politics, technology, and social demands all played a role in building communities. In the following work, Taylor County's earliest history will be examined with an emphasis on changes due to transportation developments. Although, essentially a study of social change, the story necessarily involves technological history and political, economic, and demographic concerns. Thus, the first chapter reviews construction of the Northwestern Turnpike. The second chapter examines the political dimensions of building the Baltimore \& Ohio and Northwestern Virginia railroads, and the transition of the region from turnpikes to railroads. In the third chapter, population growth and commercial elaboration accompany the de facto assimilation of Fetterman into the community of Grafton, whose status as a railroad town stands as a particularly telling artifact of the American transportation experience during the nineteenth and early twentieth centuries. 


\section{Chapter 1}

Broaching the Wilderness

Few things are of more public utility than good roads-And, unfortunately, few things are more neglected in Virginia. Our Roads are the Laughing-stock of strangers. Except a very few turnpikes, the high-ways and the bye-ways are any thing else than what they ought to be. The system itself is radically defective and our highways are commonly in the most pitiable condition. ${ }^{1}$

Understanding the effect of railroads on communities and economies in mid-nineteenth century western Virginia must begin with a survey of transportation projects after 1800. Accommodating transportation demands proved difficult for state legislators, due to the exorbitant cost of building roads and canals and conflicting agendas in satisfying transportation needs. Proposed Virginia laws and policy measures to create transportation lines benefiting Richmond and Norfolk interplayed with those of Pennsylvania and Maryland, each pursuing their own transportation systems to best serve Philadelphia and Baltimore, respectively. In seeking to exploit western lands, Virginia legislators and investors contributed to a series of events that would benefit numerous people.

Increasing numbers of subsistence-level farmers needing eastern manufactured goods and regular communications led to demands for transportation links. ${ }^{2}$ As Virginia politicians and investors of the early nineteenth century examined the use of turnpikes and canals to cross the Alleghenies, transportation improvements also fueled an important national debate.

In the early 1800 s, the United States Senate ordered the first review of national transportation

1 “The High-Ways," The Wheeling Gazette, 5 February 1831.

${ }^{2}$ George Rogers Taylor, The Transportation Revolution, 1815-1860 (Armonk, New York: M.E. Sharpe, 1951, 1989), 132-40. 
capabilities. Secretary of the Treasury Albert Gallatin completed the report in 1808. Gallatin concluded that spending public money for internal improvements was a proper investment for the common good, especially for transporting mail or troops. But Gallatin also emphasized trade, considering commercial use of roads and canals of equal if not greater consequence. He went so far as to support the calls of President Thomas Jefferson and many congressmen to institute a constitutional amendment, essentially empowering the federal government to oversee and finance internal improvements, even to the extent of foregoing approval from states when building roads and canals across political boundaries. ${ }^{3}$

The first vestiges of industrialization, already well developed in Britain and parts of western Europe, stirred interest among some Americans that technology could be brought to bear for internal improvements in the early 1800s. Internal improvements, a rather abstract term, meant building allweather roads, a nation-wide canal and river navigation system, and harbors for maximum shipping efficiency. The main purpose of improvements was to facilitate commerce and reduce shipping costs. $^{4}$

Transportation improvements would aid population centers and farms producing livestock and commercial crops for a national market. Numerous travelers already described great abundance. Fortescue Cuming, an English citizen touring the United States in 1809, noted with amazement the profusion of rich farm land and livestock along the Ohio and Mississippi rivers. Cuming gave, as example, a man named Buffington who annually walked his cattle and swine across Virginia to the

\footnotetext{
${ }^{3}$ Albert Gallatin, Report of the Secretary of the Treasury on the Subject of Public Roads and Canals, 1808, (New York: Augustus M. Kelly, Publishers, 1968), 73.

${ }^{4}$ Taylor, The Transportation Revolution, 17-22.
} 
south branch of the Potomac River for market. ${ }^{5}$ In eastern Harrison County, Virginia, Absolem Knotts observed herds of cattle, sheep, pigs, geese, and turkeys driven to market along roads that were not yet turnpikes. ${ }^{6}$

Overcoming seclusion and any related level of poverty in the mountains of western Virginia involved transportation improvements. In addition, many Americans began moving west as the War of 1812 ended. Farms, plantations, and communities along the Atlantic seaboard were becoming crowded and overused by then, with good quality, affordable land a scarce commodity for eastern yeoman farmers. ${ }^{7}$ Deplorable roads in the western mountains limited population growth, however, and led Virginia's legislators to support turnpikes as the best means to negotiate those mountains. In this context, a turnpike was an improved road upon which tolls were collected to defray construction and maintenance costs.

One of the roads improved by state planners in the mid-1820s passed along the Three Forks Creek and over the Tygart River in then southern Monongalia County. This was named the Northwestern Turnpike. Such entrepreneurs as Frederick Burdett, Alexander Smith, and John W.

${ }^{5}$ Fortescue Cuming, Sketches of a Tour to the Western Country, edited by Reuben Gold Thwaites (Cleveland, Ohio: Arthur H. Clark Company, 1904), 136.

${ }^{6}$ Charles Brinkman, “The History of Taylor County," The Grafton Sentinel, 21 April 1939.

${ }^{7}$ For an examination of eastern land shortages in the early 1800s, see Barbara Rasmussen, Absentee Landowning and Exploitation in West Virginia, 1760-1920 (Lexington: The University of Kentucky Press, 1994), 1-44; Charles Henry Ambler, West Virginia: The Mountain State (New York: Prentice-Hall, 1940), 165; John Mack Faragher, Sugar Creek: Life on the Illinois Prairie (New Haven: Yale University Press, 1986), 44-8; Steven Hahn and Jonathan Prude, The Countryside in the Age of Capitalist Transformation (Chapel Hill: The University of North Carolina Press, 1985), 14-5; John W. Reps, The Making of Urban America: A History of City Planning in the United States, (Princeton: Princeton University Press, 1965), 204; John R. Stilgoe, Common Landscape of America, 1580 to 1845 (New Haven: Yale University Press, 1982), 61-2, 186-7. 
Blue, as well as earlier settlers, such as the Luzadder family, made their fortunes due to the turnpike in the early 1800 s. The Northwestern Turnpike proved so effective at increasing commerce and population that residents of eastern Harrison County petitioned the Virginia legislature to form Taylor County in 1844. However, emerging railroad technology would make turnpikes obsolete and draw Taylor County, along with much of northern Virginia, into a national transportation system, reducing the isolation of many small communities while taking advantage of roads and turnpikes built earlier as feeder lines.

\section{Influx}

When European Americans first settled the Tygart River valley before the arrival of railroads, they found comparatively flat land with rich soil, plentiful choice timber, and consistent supplies of potable water. The valley's river took its name from David Tygart who, along with his friend, Robert Files and their families, entered the valley in 1753 in present-day northern Randolph County. ${ }^{8}$ Throughout the eighteenth century, other white settlers in the region began using Tygart's name to identify the river. ${ }^{9}$

During westward migration in the 1810 s and 1820 s, thousands of diverse individuals and families braved the Allegheny Mountains, slowly populating the hills and valleys of northwestern Virginia. Some of those migrants, particularly the Scots-Irish, found their way to the Tygart River valley where they found earlier settlers, such as the Luzadder family. "Cheap land was one of the great inducements for western emigration," reflected John W. Mason in The Grafton Sentinel of

\footnotetext{
${ }^{8}$ Ambler, West Virginia: The Mountain State, 51.

${ }^{9}$ Alexander Scott Withers, Chronicles of Border Warfare (Cincinnati, Ohio: The Robert Clark Company, 1895), 74-5; Ambler, West Virginia: The Mountain State, 53.
} 
$1876 .{ }^{10}$ Officially, land claims required careful surveying and documentation at state land offices. But new settlers often made no formal application and would simply mark a few trees to indicate ownership of a land parcel. Settlers had only to construct lodging and plant crops to stake as much as 400 acres, with "pre-emption right" for 1,000 acres, a situation which occasionally resulted in violence over claims and boundary disputes. ${ }^{11}$

To accommodate commercial shipping, migrant homesteaders, and mail delivery in Virginia, legislators recognized the need for a statewide internal improvements effort. Attempts to organize transportation improvements in Virginia can be traced to 1730. Richmond interests encouraged locally funded western transportation improvements to benefit the fledgling iron industry by requiring county justices of the peace to sustain roads from any iron foundry to the nearest navigable river. At the same time, laws exempted iron workers from corvée duty, or the periodic obligation of able-bodied men to help maintain county roads. ${ }^{12}$

In February 1816, Virginia legislators passed The Act to Create a Fund for Internal Improvement, establishing Virginia's Board of Public Works to coordinate state internal improvements projects while representing the state's interest in financing construction. The General Assembly charged the board with "rendering navigable, and uniting by canals, the principal rivers,

${ }^{10}$ John W. Mason, “Our Great Centennial Celebration,” The Grafton Sentinel, 15 July 1876.

${ }^{11}$ Ibid; Land ownership titles were informal and haphazard, being subject to dispute, until 1837 when the Virginia General Assembly codified the ownership of land in western Virginia. Essentially, the legislature offered an amnesty for delinquent state property taxes owed by any land owner whether they had previously filed a state claim or not. Refer to Acts of the General Assembly of Virginia (Richmond: Thomas Ritchie, 1837), 9-12.

${ }^{12}$ William Waller Hening, The Statutes at Large; Being a Collection of All the Laws of Virginia, volume 4 (Richmond: W.W. Gray, 1820), 296-7. 
and of more intimately connecting, by public highways, the different parts of this Commonwealth." 13

The act emphasized canals, which received the most attention from investors and politicians from the outset and led to plans for improving navigation of the Tygart River, among others, by means of a canal with locks around the "Big and Little falls" at the present-day village of Valley Falls. ${ }^{14}$ The Board ultimately concluded the futility of creating a state-wide transportation system by making western rivers navigable and employing canals to link them as initially hoped. Therefore, plans took shape by 1820 for four east-to-west turnpikes interspersed from north to south to connect all sections of the state. ${ }^{15}$ To Old Dominion legislators, Virginia's capital at Richmond and Norfolk on the James River were the only logical eastern termini of transportation lines carrying the wealth of western lands.

Several primitive roads already crisscrossed northwestern Virginia which could potentially serve Richmond and Norfolk. In eastern Harrison County, along a poorly developed byway called McCulloch's Trail, families and entrepreneurs had already gathered to live at its crossroad with the north-to-south oriented Booth's Ferry Road by 1820. Indeed, an inn and general store existed there as early as $1756 .{ }^{16}$ Attracted by geographical advantages of the area in the form of reliable water and relatively flat ground for agriculture, a small village formed. First known as Cross Roads, then as

${ }^{13}$ Acts Passed at a General Assembly of the Commonwealth of Virginia for 1815 (Richmond: Thomas Ritchie, 1816), 35 (hereafter, Acts of the Virginia General Assembly).

${ }^{14}$ Twenty First Annual Report of the Board of Public Works to the General Assembly of Virginia (Richmond: Samuel Shepherd, 1836), 499 (hereafter, Annual Report BPW).

${ }^{15}$ I.F. Boughter, "Internal Improvements in Northwestern Virginia: A Study of State Policy Prior to the Civil War" (Ph.D. dissertation, University of Pittsburgh, 1930), 112-7.

${ }^{16}$ Ledger Book 1, Clayton and Fenton collection, West Virginia and Regional History Collection, West Virginia University, Morgantown, W.Va. (hereafter, WVRHC); numerous running accounts reflect a community system of credit using barter and cash transactions on a seasonal basis. 
Williamsport, the village had the name of Pruntytown when it became the county seat of newly formed Taylor County. ${ }^{17}$

Almost from its beginning, Williamsport was also called Pruntytown. John Prunty and his brother, David, a trained surveyor, settled in eastern Harrison County in 1779, and soon laid claim to most of the land in the area. ${ }^{18}$ In 1784 , Virginia Governor Patrick Henry appointed Prunty a justice of the peace for Harrison County. By 1804, the Prunty brothers began arranging streets and town lots to accommodate settlers. ${ }^{19}$ The Pruntys so dominated the village that numerous official documents referred to Pruntytown well before Taylor County's chartering in 1844, including Northwestern Turnpike reports and Virginia legislative records. ${ }^{20}$

As a magistrate in antebellum Virginia, John Prunty was charged not only with civil dispute resolution and local law enforcement, but with levying taxes, recording various county documents, granting licenses for mills, and planning roads and bridges. ${ }^{21}$ Himself a farmer, Prunty understood the necessity for internal improvements in western Virginia. For example, accepting a responsibility to his community which also proved lucrative in land sales, he served on the planning board of the

${ }^{17}$ Taylor County Historical and Genealogical Society, A History of Taylor County, West Virginia (Parsons, West Virginia: McClain Printing Company, 1986), 14; Acts of the Virginia General Assembly (1844-45), 125; For a more complete look at the earliest migrations along northwestern Virginia's roadways see Hulbert, Historic Highways of America, volume 1, 21-2, 138-9, and A.B. Brooks West Virginia Geological Survey, volume 5 (Morgantown, W. Va.: Acme Publishing, 1910), 276-8, for a description of topography and natural resources which at once pulled and frustrated settlers.

${ }^{18}$ Brinkman, "History of Taylor County," 19 April 1939.

${ }^{19}$ A History of Taylor County, West Virginia, 14.

${ }^{20}$ Seventeenth Annual Report BPW (1833), 85; Acts of the Virginia General Assembly (1833), 98-9; Ibid (1844-45), 125.

${ }^{21}$ Dorothy Davis, History of Harrison County West Virginia (Clarksburg, West Virginia: American Association of University Women, 1970), 83. 
Alleghany Turnpike Road Company. Designed to connect Savage River and Potomac River trade in eastern Virginia to that on the Monongahela River, the company made nominal improvements to McCulloch's Trail, known locally as the Washington Post Road after George Washington had inspected his western land holdings in 1770 along this route. ${ }^{22}$

McCulloch's Trail, named for an early explorer and trapper, proved to be an excellent route across the state's northern tier. Using that route, the Northwestern Turnpike offered a virtually straight road to Parkersburg on the Ohio River from Winchester, Virginia. Williamsport's residents took best advantage of their situation and, even before becoming the county seat, could boast ten dwellings, a harness and saddle shop, a blacksmith, a gristmill, and a tavern greeting travelers on the turnpike. ${ }^{23}$ So remote was the area, however, that until completion of the turnpike, residents periodically suffered raids by pillaging "river pirates" plying the Tygart and surrounding back country. ${ }^{24}$

Settlers to the area during the early 1800s came chiefly from Maryland, southern Pennsylvania, and northeastern Virginia along convenient water routes and well traveled paths. The vast majority of early homesteaders in northwestern Virginia were of Scots-Irish descent, emigrating from the Ulster region of Ireland. Following the hunters and trappers, the Scots-Irish became the first whites intent upon permanent settlement in Virginia's western mountains. With over a quarter of a million Scots-Irish having reached America's shores by the turn of the nineteenth century, they were the largest of many new ethnic groups exploring America's frontiers for homes and

\footnotetext{
${ }^{22}$ Box 5, Virgil Lewis papers, West Virginia Division of Archives and History, Charleston, West Virginia (hereafter, WVDAH); A History of Taylor County, West Virginia, 14.

${ }^{23}$ A History of Taylor County, West Virginia, 14.

${ }^{24}$ Brinkman, "History of Taylor County," 25 April 1939.
} 
prosperity. $^{25}$

Along with the Scots-Irish, Frederick Burdett arrived at Williamsport in the late 1810s. Burdett traveled west with some of his own family, some of his bride's family, and several friends from Culpeper, Virginia, where his grandfather had settled after leaving France. They departed westward on a trip taking them more than two months. Burdett married Susan Sinsel before departing Culpeper, and provided for his new family by teaming up with Abraham Smith to open the only mercantile business in the vicinity at that time. ${ }^{26}$ The nearest merchants to Williamsport before then were over twenty miles to the north in Morgantown on the Monongahela River, or at Clarksburg and Evansville along the Washington Post Road. ${ }^{27}$

Smith became quite familiar with the roads of northwestern Virginia as a teenager. In the 1810s, he carried mail on horseback between Washington, D.C., and Marietta, Ohio, a trip that took most of a week at full gallop each way with the rider resting only when changing horses every few miles. One of his most exciting assignments came when he brought news to the nation's capital of the British naval defeat on Lake Erie by Commodore Oliver Hazard Perry in September, 1813, calling out the news as he passed towns and villages along the way. In celebration of this heralded victory, and in gratitude for faithful service, United States Postmaster General Jonathan R. Meigs appointed Smith as Williamsport's postmaster, a position he held for fifty years. ${ }^{28}$

Smith's mail service and the general store were very important to this small community.

${ }^{25}$ Mitchell, Commercialism and Frontier, 69.

${ }^{26}$ Biographical and Portrait Cyclopedia of Monongalia, Marion and Taylor Counties, West Virginia, "Taylor County," (Philadelphia: Rush, West, and Company, 1895), 38-9.

${ }^{27}$ Brinkman, "History of Taylor County," 25 April 1939.

${ }^{28}$ John W. Mason, "Our Great Centennial Celebration," The Grafton Sentinel, 15 July 1876. 
Great excitement and anticipation filled the air in the spring and fall when Burdett, Smith, or both would travel to Baltimore to purchase stores. ${ }^{29}$ On horseback from Williamsport, they would choose one of three routes: north through Morgantown; northeast to the Brandonville Turnpike in northern Preston County; or east to Cumberland, Maryland, each pathway eventually connecting with the National Road. Avoiding extra expense in tolls and horse feed, as well as improving their travel time, Burdett and Smith purchased wagons in Baltimore. After negotiating for merchandise and searching for items specially ordered by folks at home, they would buy the requisite wagons and teams at the harbor, which in turn could be sold at Williamsport, then traced the same route home. ${ }^{30}$

Already, an embryonic transportation system existed in the 1820s, including interconnected canals and turnpikes. Adjacent roads coincidentally served travelers wishing to avoid turnpike tolls. Perhaps it was Burdett's and Smith's experiences during those semi-annual supply excursions that persuaded them to keep local stock subscription records for the Northwestern Turnpike Company at Williamsport. ${ }^{31}$ They clearly understood the importance of transportation improvements for small communities.

Reflecting on human interaction and trade in villages and towns, historian Richard L. Meier observed that cities became an integral component of industrialization throughout the nineteenth century ${ }^{32}$ Community can be defined in a number of different ways, depending upon how broad or narrow the context, but all definitions are expressed in terms of people in a common group or setting.

${ }^{29}$ Brinkman, "History of Taylor County," 25 April 1939.

${ }^{30}$ Biographical and Portrait Cyclopedia of Taylor County, 39-40.

${ }^{31}$ Virgil Lewis papers, file "Chapter XIV. The Northwestern Turnpike," WVDAH.

${ }^{32}$ Oscar Handlin and John Burchard, The Historian and the City (The M.I.T. Press and Harvard University Press, 1963), 74-83. 
Historian Lewis Mumford encompassed elements of function when he identified villages, towns, and cities: "From its origins onward, indeed, the city may be described as a structure specially equipped to store and transmit the goods of civilization, sufficiently condensed to afford the maximum amount of facilities in a minimum space, but also capable of structural enlargement to enable it to find a place for the changing needs and the more complex forms of a growing society and its cumulative social heritage." ${ }^{33}$ Mumford accurately described the Taylor County communities of Pruntytown, Fetterman, and Grafton, each representing a particular level of town development: market center, flexible organization, and dense settlement.

\section{The Issue Was Good Roads}

Although generally referred to as roads, wilderness trails more appropriately described many Virginia thoroughfares, especially in the western mountains. The terrain is steep and rugged, and the valleys narrow with few level areas which would accommodate much construction. Travel under such conditions was difficult, and land freight rates were consequently high. A farmer's expected return on a bushel of wheat in the 1820s, for example, depended on the price of flour, but a miller could expect to pay as much as $\$ 5$ to ship a barrel of flour ten miles after production expenses, reducing or nullifying the grower's profit margin. ${ }^{34}$ Improvements to roads reduced shipping times, but simply widening crude foot paths to accommodate wagon teams without designs toward a smooth waterproof road surface could not solve the problems. Heavy wagons damaged road

${ }^{33}$ Lewis Mumford, The City in History: Its Origins, Its Transformation, and Its Prospects (San Diego: Harcourt Brace and Company, 1961, 1989), 30.

${ }^{34}$ John F, Stover, Transportation in American History (Publication No. 75, Washington, D.C.: The American Historical Association, 1970), 6. 
surfaces. In addition, rainfall cut rivulets and large holes into exposed surfaces, which in turn damaged wagons.

Residents of eastern cities and the Tidewater region also desired good roads and competed for support of expensive internal improvements. Moreover, eastern Virginians had far more political representation in the General Assembly than westerners. Virginia's legislators recognized that statewide internal improvements were essential, and that ignoring the problem would only defer advantage to competing Atlantic coast cities. This dilemma led directly to the Virginia Board of Public Works and the Fund for Internal Improvements, the first large-scale state-wide internal improvements movement using public money to subscribe for company stocks and bonds. Western Virginians would be connected with Norfolk and Richmond by state underwritten turnpikes and canals. $^{35}$

Both houses of the General Assembly annually voted on ten citizens to represent Virginia's tidewater, Piedmont, and western regions to occupy the Board of Public Works. ${ }^{36}$ Constituents of the Tygart valley had nearly continuous representation on the board through Edward J. Armstrong. A Taylor County attorney, active Democrat, and important participant in forming Taylor County, Armstrong remained a member of the Board through the 1850s. After serving in the Virginia House of Delegates from 1839 through 1844, he received hearty endorsements from the editors of The Richmond Enquirer and The Fairmont True Virginian for Commissioner of the Board in $1857 .{ }^{37}$ Individuals wishing to purchase turnpike stock could do so through neighbors selected by the

\footnotetext{
${ }^{35}$ Boughter, "Internal Improvements in Northwestern Virginia," 94-102.

${ }^{36}$ Acts of the Virginia General Assembly, 35-6.

37 “Taylor County," The Fairmont True Virginian, 31 January 1857; "Board of Public Works," The Fairmont True Virginian, 7 February 1857.
} 
Northwestern Turnpike Company. Pruntytown residents Frederick Burdett, Thomas Gethrop, Stephen Neill, Cornelius Reynolds, and Abraham Smith, all local businessmen, kept turnpike stock subscription books during its construction. ${ }^{38}$ They solicited merchants and local farmers during the 1830s for small stock purchases. Stock subscriptions sold for $\$ 50$ per share, and to make subscription easier, turnpike administrators created payment plans especially tailored for investors of modest income, such as millers, small farmers, and artisans, where they accepted $\$ 3$ installments. ${ }^{39}$

\section{Turnpike}

Among workers building the Northwestern Turnpike through northern Virginia in the early 1830s were Stephen, Isaac, and John Wolverton Blue. A key construction contractor selected for the job by Hampshire County, Virginia, neighbor, Claudius Crozet, John Blue had charge of building the Cheat Mountain to Tygart River section. Blue would later become an eminent Taylor County businessman and land owner. But first, he supervised constructing one section of the region's earliest improved roads and its bridge at the Tygart River. ${ }^{40}$ Before finishing his job, however, John Blue would benefit from the misfortune of a family in the path of construction.

While supervising construction crews in 1832, John Blue discovered country "very much broken, the hills steep on all sides—and the ravines deep and irregular." ${ }^{41}$ Building across the

\footnotetext{
${ }^{38}$ Virgil Lewis papers, file "Chapter XIV. The Northwestern Turnpike," WVDAH.

${ }^{39}$ Advertisement, Cooper's Clarksburg Register, 3 December 1851.

${ }^{40}$ A History of Taylor County, West Virginia, 16, 157-8; Brinkman "History of Taylor County," 2 May 1939; Taylor County Clerk of Courts (hereafter TCCC), Land Books 1848

41 “Northwestern Turnpike,”Western Enquirer (Clarksburg, Va.), 18 August 1832.
} through 1863, passim. 
Allegheny Mountains involved thoughtful engineering. Claudius Crozet called it "a country at present almost a wilderness and where comforts are unknown. I should consider fifty miles as the greatest distance that should exist between any two great leading roads, in order that they might be easily accessible from every point." 42 The need for elongated S-curves in many places added miles and hours to trips along the turnpike, but overcoming Chestnut Ridge near the Taylor and Preston county line offered an especially weighty challenge. Keeping grades reasonable to accommodate both the stamina of horse teams and drivers' proficiency competed with the need to keep the route as short as possible. There proved little choice but to build rather long, complicated, and time consuming switchbacks for parts of the selected route. Twenty years later, the Baltimore \& Ohio company had to spend great sums overcoming the same problem, bridging chasms large and small, and tunneling unprecedented distances to save miles and time.

The roadway proper constantly underwent routine maintenance, improvements, and realignment as well. For example, in Williamsport, workers moved the Northwestern Turnpike even before they finished the road. In 1833, Virginia legislators approved realigning the road from passing around the town to a route through the center of town more advantageous to business operators on Main Street. As required in the act, Williamsport residents repaid the state's fund for internal improvements for this project "within a reasonable time." 43 When the job was completed in 1844 , Williamsport taxpayers refunded $\$ 56.12$ to state coffers. ${ }^{44}$

While working on the turnpike, John Blue and his brothers lived with the James and Margaret Current family in present-day Blueville. In September 1836, route alignment of the turnpike brought

\footnotetext{
${ }^{42}$ Twenty Fourth Annual Report BPW (1839), 22.

${ }^{43}$ Acts of the Virginia General Assembly (1833), 98-9.

${ }^{44}$ Twenty Ninth Annual Report BPW (1844), 443.
} 
the right-of-way near the Currents' house and through the vegetable garden, distressing Mrs. Current because she had to relocate and replant her garden, resulting in at least a year with meager provisions. They were staggered by the situation, which finally brought Mrs. Current to tears. ${ }^{45}$ John's brother, Isaac Blue purchased the house and 300-acre farm, which stretched south to the Three Forks Creek. He and the Currents agreed on a $\$ 1,200$ purchase price, but Blue could only pay $\$ 800$ at the time. ${ }^{46}$ Blue paid $\$ 4$ per acre, or about high average price for the time according to county tax records. Changes brought by the turnpike caused the Currents to move to Indiana in 1836, away from encroaching civilization. ${ }^{47}$ Blue finished paying the $\$ 400$ balance to Abraham J. Current, acting as James' agent, on 22 October $1838 .{ }^{48}$

At Fetterman, terrain dictated construction of a turnpike bridge over the Tygart River. Although shallow rapids at the river's bend near Fetterman provided easy fording at low water, a bridge allowed for year-round use of the route. John Blue supervised erecting the covered bridge, with a planned crossing of 306 feet. $^{49}$ He contracted Zedekiah Kidwell to construct the bridge. ${ }^{50}$ Owing to a small island in the middle of the channel, the bridge could be built in two spans, 24 feet above the water at summer stage, measuring 150 feet each, excluding approaches, with a substantial cut-stone center pier which still stands. ${ }^{51}$ Northwestern Turnpike superintendent Josiah D. Wilson, concerned with damage to the structure during floods, specified raising it five feet, delaying the

\footnotetext{
${ }^{45}$ Brinkman, "History of Taylor County," 2 May 1939.

${ }^{46}$ Monongalia County Clerk of Courts Office, Deed Book O.S. 14, 96-7.

${ }^{47}$ A History of Taylor County, West Virginia, 157-8.

${ }^{48}$ Monongalia County Clerk of Courts Office, Deed Book O.S. 14, 570.

${ }^{49}$ Brinkman, "History of Taylor County," 2 May 1939.

${ }^{50}$ Hunter, "The Turnpike Movement in Virginia," 191.

${ }^{51}$ Seventeenth Annual Report BPW (1833), 84-6.
} 
Tygart bridge and approaches enough to be the last section completed on the Northwestern Turnpike in Virginia. ${ }^{52}$

Even after its completion in 1840, almost two years after the turnpike had opened, unusual maintenance requirements for the covered bridge often compelled Fetterman residents and turnpike patrons to again ford the river. Just after opening, for example, snow collapsed the roof, costing $\$ 300$ for renovations and closing the bridge. ${ }^{53}$ In truth, the original bridge was poorly built, noticeably sagging, and needing constant, expensive repairs. Through Wilson's urging, measures to strengthen the Tygart River bridge commenced in 1848, despite his concern that improvements "would be nearly equal in cost to a reconstruction." 54 Wilson interviewed the oldest residents along the river for their observations to calculate maximum water levels that the bridge would encounter. ${ }^{55}$ After raising the bridge an additional eighteen inches for good measure, sufficient bracing and supports helped it to withstand weather and hard use by 1852 at a total cost of $\$ 5,389 .{ }^{56}$

After the Northwestern Turnpike opened, John Blue and his family settled in the Tygart valley. The green rolling hilltops following the Tygart River provided an inviting setting to Blue, and the turnpike was, indeed, increasing property values along the route. In October 1841, Blue purchased the land "known by the name of the Current farm" from Isaac Blue, who by then had settled near Parkersburg. The brothers reckoned that a fair price for the farm would be $\$ 3,500$, an

52 Twenty Second Annual Report BPW (1838), 404, 406, 408.

${ }^{53}$ Twenty Fifth Annual Report BPW (1840), 476.

54 Thirty Third Annual Report BPW (1848), 503.

55 Twenty Eighth Annual Report BPW (1843), 140.

${ }^{56}$ Thirty Seventh Annual Report BPW (1853), 137; The bridge stood until June 1888 before being carried away by one of the Tygart's notorious floods. 
increase of $\$ 2,300$, or nearly double what Isaac Blue had originally paid. ${ }^{57}$ To supplement his farm income, Blue built a ten-room tavern near his home along the turnpike, claiming a worth of $\$ 4,000$ by $1850 .^{58}$ In addition, Blue served as bridge tender and toll collector for the turnpike's Tygart River crossing. He entrusted the farm and tavern to his brother, William, and his wife, Mary Margaret Haymond Blue. Blue lived at the toll keeper's cottage less than two miles west in Fetterman. John Blue's wife, Mary Blue, lived at the more comfortable setting of the farm house where she could also help tend to the tavern business. ${ }^{59}$

After completion of the Northwestern Turnpike, Edward J. Armstrong and Leonidas S. Johnson saw the onset of growth in the lower Tygart River valley draw increasing amounts of traffic to towns like Fetterman and Williamsport. Both practicing lawyers and land holders at Pruntytown, they began petitions to the General Assembly to create Taylor County early in $1844 .{ }^{60}$ Citing the extreme inconvenience-almost impossibility during inclement weather-of traveling to Morgantown if one resided in southwestern Monongalia County, or Clarksburg if from eastern Harrison County to transact business, Johnson suggested that Taylor County would draw upon parts of Monongalia, Harrison, and Barbour counties. ${ }^{61}$ Thomas Haymond pressed to name Taylor County for the trans-montane hero Joseph Doddridge. Tidewater interests in the state Senate overruled

${ }^{57}$ Monongalia County Clerk of Courts Office, Deed Book O.S. 17, 92-3.

${ }^{58}$ A History of Taylor County, West Virginia, 16-7, 157; Brinkman, "Early History of Grafton," The Grafton Sentinel, 5 September 1929; United States Bureau of the Census, 1850 manuscript records for Taylor County, Virginia, household 301.

${ }^{59}$ A History of Taylor County, West Virginia, 157; Brinkman, "History of Taylor County," 2 May 1939.

${ }^{60}$ A History of Taylor County, West Virginia, 14; Biographical and Portrait Cyclopedia of Taylor County, 14-6.

${ }^{61}$ Kanawha Republican (Charleston, Virginia), 25 January 1844. 
Haymond's efforts in order to honor John Taylor of Caroline County. ${ }^{62}$

The governmental seat would be the region's largest community, Williamsport. As the town's largest landholder, John Prunty objected to the small size of the proposed county and did not favor his home town being disrupted by becoming the county capital. He threatened to hold out against all such efforts. Only after supporters of the new county pledged to officially re-name the town in his honor did John Prunty embrace the change. ${ }^{63}$

In organizing the new county's governmental structure between 1844 and 1846, land transactions held an important role. The ability to reach the county seat and return home within a day simplified recording such transactions and proved a common argument for forming new counties in Virginia before the Civil War. An important commodity, land provided excellent security for pioneer families as it could be timbered and farmed, or sold if need be. A conspicuous measurement of wealth, it could be worked to provide a home and livelihood, then passed on as a legacy to future generations. $^{64}$

The order of business for Taylor County's new “gentlemen justices," or the county's governing body, placed land parceling and deeding as high priorities, following on the organizational

agenda only after selection of the clerk of courts, sheriff, and county coroner. ${ }^{65}$ The office of county surveyor went to Harmon Sinsel. He would later serve on the county court, or county government,

${ }^{62}$ Ibid, 1 and 15 February 1844; Wiley, 291.

${ }^{63}$ A History of Taylor County, West Virginia, 14; Brinkman, "History of Taylor County," 1 May 1939.

${ }^{64}$ Christopher Clark, "Rural America and the Transition to Capitalism," Journal of the Early Republic, 16 (Summer 1996): 225-7.

${ }^{65}$ Brinkman, "History of Taylor County," 26 April 1939. 
and as an eleven-term district magistrate. ${ }^{66}$ The grandson of a Hessian soldier during the American Revolution, Sinsel was a trained millwright who repaired mills and water works in western Virginia destroyed by British soldiers during the War of 1812. After the war, he settled at Pruntytown. He also worked as a house joiner, but Sinsel's mathematical skills, honed at Rector College in Pruntytown, helped him hold the office of county surveyor for most of his adult life. ${ }^{67}$

Unfortunately, adding Taylor County's one representative to the Virginia House of Delegates rendered little support for the cause of western transportation improvement. ${ }^{68}$ Western Virginians harshly criticized the Board for concentrating energies on eastern roads and canals, and virtually ignoring western improvements. Some western representatives called for abolishing the board entirely as it misused the Fund for Internal Improvements by serving only Richmond and the Tidewater region. State representative William Goode of Mecklenburg County, who led the attempt, charged the Board of Public Works with being "a Fungus upon the Fund." ${ }^{69}$ These efforts never received much legislative support, yet they exhibited the rift between eastern and western concerns and laid the groundwork for later western support for out-of-state railroad ventures.

Despite objections and political wrangling over internal improvements, the new Northwestern Turnpike had an immediate effect in the 1840s. At Pruntytown, three taverns opened in addition to new homes and a courthouse. ${ }^{70}$ One of those taverns belonged to Henry Mahaney. To attend

${ }^{66}$ Ibid, 27 April 1939.

${ }^{67}$ Ibid; Biographical and Portrait Cyclopedia of Taylor County, 25-7.

${ }^{68}$ Cynthia Miller Leonard, The General Assembly of Virginia, June 30, 1619-January 11,1978: A Bicentennial Register of Members (Richmond: Virginia State Library, 1978), 427.

69 "House of Delegates," Clarksburg Enquirer, 20 February 1830.

${ }^{70}$ A History of Taylor County, West Virginia, 14-5; A lack of county records for this period makes verification of public houses problematical. 
travelers, teamsters, stage drivers, and herders, Mahaney offered lodging at 25 cents per night and meals for the same price. Servings of whiskey and home-made apple brandy sold for five cents, a price set in 1792 by the Virginia legislature. ${ }^{71}$ In the late 1840 s, Dr. A.S. Warder took up residence and opened an office at Mahaney's Tavern, adding to the thriving town. ${ }^{72}$

With construction completed, numerous small taverns and inns sprang up along the Northwestern Turnpike. Traveling America in the early 1800s, English emigré Morris Birkbeck recorded remarks about various country inns. Although never visiting Harrison or Monongalia counties, his observations apply to any number of taverns in America, including those on the Northwestern Turnpike. At American inns, "all is performed on the gregarious plan."73 Birkbeck wrote with amazement that every facet of overnight lodging was en masse, with little if any attention to the needs of individual travelers, a stark contrast to continental savoir faire. For each meal, a ringing bell summoned patrons to the dining room, where they served themselves from caldrons and bowls presented at the table. Although the number of guests varied, and could add up to one hundred, meals were consistently large and diverse, offering eggs, cheese, beef or pork, fowl, fish, a variety of breads with butter, milk, coffee or tea, "and more than you can think of."74 As bed time approached, "you assemble once more, in rooms crowded with beds, something like the wards of an hospital; where, after undressing in public, you are fortunate if you escape a partner in your bed, in

\footnotetext{
${ }^{71}$ Certain Acts of the General Assembly of the Commonwealth of Virginia, 1792-3
} (Richmond: Samuel Shepherd, 1835), 142-5.

${ }^{72}$ Pruntytown Gazette, 10 May 1855.

${ }^{73}$ Morris Birkbeck, Notes on a Journey in America (Ann Arbor: University Microfilms, Inc., 1966), 36.

\footnotetext{
${ }^{74}$ Ibid, 37.
} 
addition to the myriads of bugs, which you need not hope to escape." ${ }^{, 75}$

Transition

By the late 1820s, the new railroad technology imported from Great Britain and undergoing modifications to accommodate American needs, began to supplant turnpikes. The early nineteenth century was a time of revolutions in transportation, and, although a new technology, rail roadways were gaining in popularity. Small specialized mechanical tramways already operated in Massachusetts and Pennsylvania by 1826. Maryland legislators chartered the Baltimore \& Ohio Railroad Company in $1827 .^{76}$

Many northwestern Virginians desiring internal improvements could follow the efforts of the Baltimore \& Ohio Railroad through the local press, and Harrison County newspapers carried stories of the railroad's progress from the very beginning. Residents of the Tygart valley learned in September 1827 that surveying parties had already slowly but surely worked their way west from Winchester, Virginia, examining routes for the new road. ${ }^{77}$ The United States Army Corps of Topographic Engineers assigned surveyors to the Baltimore \& Ohio for the planning phase of the western route. The United States government essentially loaned army engineers to help civilian internal improvement projects under authority of the General Survey Act of 1824, making available practically the only people trained in engineering in the country at the time. ${ }^{78}$ In the bargain, a dozen young army officers gained invaluable experience to augment their West Point education, furnishing

\footnotetext{
${ }^{75}$ Ibid.

${ }^{76}$ Dilts, The Great Road, 45.

77 “Baltimore and Ohio Rail Road," Clarksburg Enquirer, 1 September 1827.

${ }^{78}$ Stover, History of the Baltimore and Ohio Railroad, 20-4.
} 
the only aid that the federal government would extend to the $\mathrm{B} \& \mathrm{O}$ until it became a critical link for the Union's war efforts during the Civil War. ${ }^{79}$ Lieutenant Isaac R. Trimble, for example, garnered the attention of Harrison County residents while leading a small team surveying proposed routes. ${ }^{80}$ Each new story of progress heightened expectations among local residents as when B\&O directors announced in December 1827 that preliminary surveys had been completed to Harpers Ferry, Virginia, and three teams of engineers had been sent out to make the final route selection to the Ohio valley. ${ }^{81}$

By July 1828, the B\&O Railroad and Chesapeake \& Ohio Canal companies were both engaged in construction on a scale at all levels comparable to that of the great Roman aqueducts. Both companies aspired to lay integral, continuous roads traversing the daunting Allegheny Mountains. In South Carolina, the legislature had also chartered the Charleston \& Hamburg Railroad Company. ${ }^{82}$

A race had begun among eastern investors and competing cities wherein turnpikes would continue to be built throughout the nineteenth century. But the essence of internal improvement debates could be reduced to a question of old technology versus new: a choice between turnpikes, which used techniques centuries old, and railroads which combined steam driven engines and vast roads of iron rails. On Independence Day, 1828, Charles Carroll turned a spade of earth, inaugurating construction for the Baltimore \& Ohio Rail Road Company, declaring his modest participation in such a momentous event an honor rivaling his signing of the Declaration of

\footnotetext{
${ }^{79}$ Dilts, The Great Road, 64.

${ }^{80}$ Clarksburg Enquirer, 1 September 1827.

${ }^{81}$ Ibid, 13 December 1827.

${ }^{82}$ Taylor, The Transportation Revolution, 75-8.
} 
Independence over five decades before. On that same day, President John Quincy Adams dedicated ground breaking ceremonies for the Chesapeake \& Ohio Canal Company along the Potomac River near Georgetown, Virginia. ${ }^{83}$ Many Americans believed that a new age had dawned, and excitement did not waiver, even when the Charleston \& Hamburg experienced America's first locomotive boiler explosion in 1831, killing one of the operators. ${ }^{84}$

Initially, Virginia's legislators virtually ignored railroads as the most effective way to cross the mountains. The technology was infantile and, during the 1830s, garnered scanty popular support, save for small groups of enthusiastic boosters, such as the editor of the Clarksburg (Virginia) Enquirer who wrote, "steam is effecting greater changes in the world almost, than the discovery of the art of printing, or that of the American Continent." ${ }^{85}$ Some highly regarded engineers and mechanical experts also had full faith that railroads could develop into a critical component of land transportation to suit a continent. Claudius Crozet, Virginia's chief engineer, supported railroads as the only practical way to cross the Allegheny Mountains as early as the 1830 s, for example. His pragmatic training at the Ecole Polytechnique in France, combined with hard won experience as an engineering officer under Napoleon Bonaparte and as supervisor of internal improvements projects within the state, led him to heartily support railroads. ${ }^{86}$ Yet, faith in canals and turnpikes by

${ }^{83}$ Dilts, The Great Road, 7-11, 100-1.

${ }^{84}$ Eugene Alverez, Travel on Southern Antebellum Railroads, 1828-1860 (The University of Alabama Press, 1974), 7.

${ }^{85}$ Clarksburg Enquirer, 20 February 1830, 1.

${ }^{86}$ Informed by Roman technique, French road building expertise was well regarded and widely emulated in Europe and America. For a synopsis of Roman, French, and British road engineering, see Emory L. Kemp, A History of the Weston and Gauley Bridge Turnpike (Report for the United States Army Corps of Engineers, 1979), 3-5, Figure 1; for a review of France's Central School for Public Works and the Ecole Polytechnique, see William Couper, Southern Sketches, Number 8, First Series, Claudius Crozet: Soldier, Scholar, Educator, Engineer, 1789- 
politicians and investors as the least expensive, and potentially more profitable ventures, stymied commercial and industrial growth in Virginia until after the Civil War when railroads became the primary means of transport.

Baltimore capitalists employed railroad technology that would cheat Richmond investors of their dreams to make Norfolk a seaport competitive with New York or Philadelphia. Inspired largely by the success of steam-powered watercraft, British railroads, and fledgling railroad projects in Massachusetts, Pennsylvania, South Carolina, New York, and Maryland, a sense of anticipation that railroads would improve the lives of the people it touched predominated, even if few understood the complexities of the problem. One person who did understand such problems and still championed railroads was Claudius Crozet. Recognizing the threat posed by the Baltimore rail line to planned commerce for Richmond and Norfolk, Crozet pleaded with Virginia legislators and the Board of Public Works to build railroads. He argued that railroads were no more expensive to build than canals or turnpikes, especially in the western mountains, and could convey larger loads ten times faster than by either mode. He saw railroads as inevitable throughout the southern states regardless of resistance by tradition-bound interests. "It will come," wrote Crozet, and to later convert surface roads to railroads in order to keep pace with other cities would present a prohibitively expensive challenge. ${ }^{87}$ However, Crozet argued to little avail. Save for a handful of chartered railroads centered on commercial use of the James, Potomac, and Shenandoah Rivers, investors and politicians remained focused on canals and turnpikes.

The growth of villages like Fetterman and Pruntytown due to turnpikes only whetted desires

\footnotetext{
1864 (Charlottesville, Virginia, 1936), 7-8.

${ }^{87}$ Sixteenth Annual Report BPW (1832), 405-6.
} 
for better transportation. Although still new in the 1840 s, railroads were an important innovation in the evolution of land transportation. But according to historian Robert Hunter, "there were some to whom this was not yet apparent in the early forties," such as some private investors and politicians in the Virginia legislature. ${ }^{88}$ Despite a general devotion to canals and turnpikes, though, a few legislators and investors did become railroad boosters, recognizing that if railroads could meet the promises of high speed transportation at low cost, they preferred to see Virginians take a leading role.

Railroads promised to draw isolated areas into larger economies. In his analysis of frontier transition from rudimentary agrarian economies to market capitalism, historian Allan Kulikoff presented an analysis of economic growth in the American northeast and upper south. Kulikoff's conclusions succinctly reflect conditions in early Taylor County. A series of essentially autonomous, family owned farms with tenuous links to a national market economy in the turnpike era delineated the region. ${ }^{89}$ Kulikoff defined transitional as "either an intensification of capitalist production or a transformation from a noncommercial or at least noncapitalist economy to a capitalist one."90 America's commercial economy of the early to mid-1800s moved beyond local and subsistence markets to a national one. Markets were at once places and abstract processes dictated by custom or rule according to Kulikoff, and steam railroads made many rules and places of commerce obsolete while creating new ones.

Railroad boosters invested money and enthusiasm in the $\mathrm{B} \& \mathrm{O}$ as the most promising of

${ }^{88}$ Hunter, 175.

${ }^{89}$ Allen Kulikoff, "The Transition to Capitalism in Rural America," The William and Mary Quarterly, third series, 46 (January 1989): 120-2.

${ }^{90}$ Ibid, 125. 
internal improvements in the mid-1800s, with the hope that freight carriage would provide a profit. Moreover, many people shared a need and desire to travel, not only for business and commerce, but for pleasure, a trait particularly prevalent in Americans. In describing Americans' wayfaring nature, Morris Birkbeck wrote in his journals that "they are great travellers; and in general better acquainted with the vast expanse of country, spreading over the eighteen states, (of which Virginia alone nearly equals Great Britain in extent,) than the English with their little island." ${ }^{\text {91 }}$ Railroad technology made possible personal mobility and a nation-wide economy with the $\mathrm{B} \& \mathrm{O}$ railroad and communities along its route playing a major role. ${ }^{92}$

However, the company's difficulty in financing construction, disagreement within the $\mathrm{B} \& \mathrm{O}$ board of directors over destination, and disputes between $\mathrm{B} \& \mathrm{O}$ officials and legislators in Maryland and Virginia over route alignment exacerbated slow progress of the main stem, as $\mathrm{B} \& \mathrm{O}$ officials referred to their main line of operations between Baltimore and the Ohio River. The B\&O reached Harpers Ferry, Virginia, in 1837, ten years after its first charter, where it made an important connection with the Winchester \& Potomac Railroad running along the Shenandoah River, but construction did not progress for three years. ${ }^{93}$ During that time, the Chesapeake \& Ohio Canal Company beleaguered the $\mathrm{B} \& \mathrm{O}$ with legal and political maneuvering in hopes of gaining a monopoly right-of-way along a narrow strip of Potomac River shoreline east of Harpers Ferry. ${ }^{94}$ Resuming in 1840, construction again halted at Cumberland at the B\&O's depot on the National

${ }^{91}$ Birkbeck, 34.

92 Taylor, The Transportation Revolution, 17-22.

${ }^{93}$ Stover, History of the Baltimore and Ohio Railroad, 39.

${ }^{94}$ For further information on the conflict between the Chesapeake \& Ohio Canal and Baltimore \& Ohio Railroad companies, see Dilts, The Great Road, 62, 67, 102-21; Stover, History of the Baltimore and Ohio Railroad, 14-5, 29, 39, 142. 
Road in 1842 due to insufficient funds.

Making their final route selections, surveying teams passed through Fetterman in $1844 .{ }^{95}$ There, the $\mathrm{B} \& \mathrm{O}$ main stem would intersect the Northwestern Turnpike for the second time, the first being at Thornton, Virginia, in eastern Taylor County. By 1849 Baltimore \& Ohio president Thomas Swann could confidently report to stock holders that the railroad stood poised for the last westward drive past Cumberland on to Wheeling and the Ohio River. In the process, the B\&O main stem broached areas for the most part avoided in the westward advance. Swann assured stockholders that railroads would change the way people and goods moved. That came as welcome reassurance to the homesteaders of trans-Appalachian northern Virginia. Newspaper reports and popular publications assured farmers around Pruntytown and Fetterman that a successful railroad would, more quickly than any other option, provide an inexpensive way to export excess farm production and import manufactured goods. ${ }^{96}$

In the late 1830s, farmers and business operators along the Northwestern Turnpike began adapting to markets beyond community and subsistence economies. With the proliferation of railroad technology and steam locomotives in the 1840 s and 1850 s, settlements and machinery increasingly subsumed previously pastoral settings. But railroads gave farmers within twenty to thirty miles of Grafton an advantage in shipping costs far lower than those charged by turnpike teamsters, as will be examined in the following chapter. By contrast, a significant increase in average farm production during the turnpike era would have led to gluts of local markets because of prohibitive shipping costs, a situation which railroads could easily remedy.

${ }^{95}$ Dilts, The Great Road, 316.

96 Taylor, The Transportation Revolution, 132-5; "Influence of Railroads on Agriculture," American Railway Times (13 June 1850): 1. 


\section{Chapter 2 \\ Politics and Iron Horses}

Whenever we lay a road across a State, whether it connects the West directly with the East, or only with some central commercial point in the West, just so often do we open to market a band of country as long as the road, and thirty, forty, or fifty miles wide. ${ }^{1}$

To strengthen their city's competitive position against New York, Philadelphia, and Richmond, Baltimore businessmen decided to finance a railroad to the inland waterways of the Ohio and Mississippi rivers, using a system that seemed to them tailor-made for moving heavy, bulky loads through difficult terrain. ${ }^{2}$ The stark reality of the Allegheny Mountains loomed as a great barrier for a technology that had barely progressed beyond theory by the 1830s, but with each day, Baltimore's railroad advanced westward across Maryland. Indeed, the B\&O shared some common characteristics with such railroads as the Charleston \& Hamburg, the most pertinent of which was the fact that they were city projects. Virtually all of the operational funding came from municipal bonds, public stock subscriptions, and private loans. ${ }^{3}$

Building railroads at the time required political support for laws favorable to operations and for state issued charters. Without a charter, funding a railroad would be nearly impossible. State and local political support often simplified overcoming such obstacles as land acquisition or sale of stock subscriptions. 642.

1 "Railway-Engineering in the United States," The Atlantic Monthly 2 (November, 1858):

${ }^{2}$ John H.B. Latrobe, Personal Recollections, a lecture delivered before the Maryland Institute, 23 March 1868 (Baltimore: The Sun Book and Job Printing); for a detailed discussion of proposed options see Dilts, The Great Road, 13-24; see Hungerford, The Story of the Baltimore \& Ohio Railroad, volume 1, 212-5 for a review of Baltimore \& Ohio Company ambitions for Cincinnati, Chicago, and St. Louis as destinations.

${ }^{3}$ Frey, Railroads in the Nineteenth Century, xvi, xviii. 
In addition, successful ventures boasted capable engineers, well trained employees, and reliable equipment combined with financial savvy and dependable markets. In railroading terms, markets are largely determined by moveable commodities that can be sold at a profit large enough to easily pay for shipping. By far, turnpike shipment was the most expensive method. Four to six horses could pull about four tons by wagon. During the 1840s, moving one ton of freight one mile by horse team cost approximately $\$ 15$. Water transportation was the least expensive, costing approximately 37 cents per ton per mile. But transport by boat was slower even than by wagon. By railroad, one ton of freight could be shipped for $\$ 1$ to $\$ 2$ per mile, and would complete the trip in hours as opposed to days and weeks. ${ }^{4}$

Obstacles such as terrain, occasional floods, and severe winter storms could severely hamper cost-effective railroad operations if not anticipated in the planning stages. In addition, B\&O administrators faced hindrances such as securing a work force, sporadic outbreaks of disease, acquisition of private land for main stem construction, opponents of railroads in some places, and economic panics. At risk for the Baltimore \& Ohio Company were personal and corporate reputations, future commercial plans, and the investments of hundreds of stock holders and loan guarantors. ${ }^{5}$ By the 1840 s, the advent of steam-powered railroads provided political leaders, commercial investors, and visionaries a realistic means of conquering the Allegheny Mountains, but only if the potential of this new technology could be realized. With failure, large investments, city prestige, and commerce would be lost.

\footnotetext{
${ }^{4} \mathrm{Ibid}, \mathrm{xv}$ and $\mathrm{xviii}$ for a review of antebellum freight carriage and fees.

${ }^{5}$ Dilts, The Great Road, 106-7, 208, 247-51, 273-4, 326-36.
} 


\section{Making Tracks}

Baltimore \& Ohio Company officials were far more concerned with completing the main stem to the Ohio River than with building communities. Nonetheless, the B\&O, passing through areas of low population density, made community development inevitable. In crafting quality transportation on a mass scale, however, a new type of community emerged that was akin to a seaport town but looking to the land rather than the ocean. American commerce in land-based commodities and markets often had to contend with distances equating a maritime scale. Like steamships, railroad trains overcame distances and ran for commercial purposes. But unlike oceanbound vessels, trains were highly dependent on route selection because of geography, often times facilitating community growth in isolated places.

Even if railroads contributed significantly to community development, financing construction remained a major stumbling block. During the spring of $1837, \mathrm{~B} \& \mathrm{O}$ construction halted for want of financing. The economic panic that then gripped the nation stopped chief engineer Benjamin $\mathrm{H}$. Latrobe, Jr., and his crews at Harpers Ferry, Virginia. "The panic of 1837 loosened the political moorings of the thirties," noted economic historian Reginald C. McGrane. ${ }^{6}$ Large-scale projects like railroads suffered financially. For the B\&O, money had always been a problem, and the national economic panic placed the line under extraordinary pressure. Funding relied entirely on loans and stock subscriptions in the antebellum era, some from state and municipal entities. Any accrued income was immediately used to cover daily operating expenses with little left over even for routine maintenance, to the great frustration of $\mathrm{B} \& \mathrm{O}$ president Louis McLane. ${ }^{7}$ To make matters worse,

\footnotetext{
${ }^{6}$ Reginald Charles McGrane, The Panic of 1837: Some Financial Problems of the Jacksonian Era (New York: Russell \& Russell, 1965), 145.

${ }^{7}$ Dilts, The Great Road, 318.
} 
their locomotives and rolling stock—a railroad term referring to any freight or passenger car — could not handle the level of traffic on the road in the late 1830 s. $^{8}$

With the B\&O main stem still almost 150 miles away from the lower Tygart valley in the early 1840s, entrepreneurs like Edward Armstrong, Abraham Smith, Frederick Burdett, and John Prunty doggedly championed the Northwestern Turnpike project as the best financial benefit to the community. As construction of the turnpike progressed, and the promise of a railroad in the future, some established residents began buying more land than they worked for farming, intending to take advantage of land price increases after the completion of internal improvements. Speculators often found encouragement in the observations of governmental officials and learned experts, such as Crozet. A worldly and respected engineer, Crozet espoused faith that the Northwestern Turnpike would increase land values and lead to community growth in northwestern Virginia.

Even before its completion and during the present trying times [1838], the price of land has advanced along it from 4 to 10 times its original value. The population and the clearings are daily increasing, and a great number of enterprising Pennsylvanians have removed to that district of the state. Such a course will be the consequence of other roads through the formidable central range of mountains of Virginia. ${ }^{9}$

In the Tygart valley, residents were also affected by the financial panics of 1837 to 1840 .

Production in crops, coal, and locally manufactured goods shipped on the Northwestern Turnpike before 1837 dwindled for lack of markets. ${ }^{10}$ Money became a scarce commodity, and the early cries for transportation improvements that ostensibly would enhance local commercial prospects increased among western Virginians. Local historian Charles Brinkman described life and politics in the area

\footnotetext{
${ }^{8}$ Hungerford, The Story of the Baltimore \& Ohio Railroad, volume 1, 191-201.

9 Twenty Fourth Annual Report BPW (1839), 22.

${ }^{10}$ James Roger Sharp, The Jacksonians versus the Banks: Politics in the States After the Panic of 1837 (New York: Columbia University Press, 1970), 247.
} 
as transfigured by the national panics. With little cash available, debtors often threatened landlords and debt collectors with bodily harm during these times, and occasionally carried out those threats. ${ }^{11}$

Opening the western part of the Northwestern Turnpike in 1838 alleviated some of the financial instability experienced by local farmers and business operators. However, the Baltimore $\&$ Ohio Company had trouble recuperating from the panics. B\&O administrators were in no position to attempt reaching Pittsburgh, their preferred destination. As such, conditions of their 1828 Pennsylvania charter requiring that the $\mathrm{B} \& \mathrm{O}$ line reach Pittsburgh within fifteen years could not be fulfilled, and by the time the $\mathrm{B} \& \mathrm{O}$ was again solvent in the late 1840s, the charter had expired. Mainly through opposition from the rival Pennsylvania Railroad, the B\&O's Pennsylvania charter would not be renewed until the 1870 s. $^{12}$ Latrobe had to seek out a route to the Ohio valley that would not enter Pennsylvania. The terrain of the Cheat and Tygart river valleys proved most promising as an alternative route which would then skirt westward along the Virginia border with Pennsylvania.

In 1842, bolstered by economic stability and loans from the city of Baltimore and Baring Brothers' investment house of London, construction commenced westward out of Cumberland. ${ }^{13}$ But, despite an improving economy, Virginia's legislators hesitated to afford any advantage for their trade rivals at Baltimore. At the same time, westerners demanding transportation improvements continued to beleaguer lawmakers. To compromise, politicians and eastern Virginia investors would only concede a $\mathrm{B} \& \mathrm{O}$ terminus at Wheeling on the Ohio River if they were to grant a charter at all,

${ }^{11}$ Charles Brinkman papers, box 2, folder 12, WVRHC.

${ }^{12}$ Dilts, The Great Road, 315-6; for an analysis of the rivalry between the Baltimore \& Ohio and Pennsylvania railroads from the B\&O's perspective, see Hungerford, The Story of the Baltimore \& Ohio Railroad, volume 1, 214.

${ }^{13}$ Stover, History of the Baltimore and Ohio Railroad, 51-2. 
reserving southern Ohio River ports such as Ravenswood and Charleston for Richmond and Norfolk based railroads. $^{14}$

However, as late as 1847 , the B\&O's board of directors still were arguing over Pittsburgh, Wheeling, and Parkersburg as the best destination point on the Ohio River, although the Virginia legislature, working within their own agenda, wanted Wheeling to be the terminus as early as $1838 .^{15}$ Wheeling investors had already pledged $\$ 1,000,000$ in stock subscriptions, with the Commonwealth of Virginia subscribing for an additional $\$ 1,058,000$ on condition the $\mathrm{B} \& \mathrm{O}$ be built to Wheeling. ${ }^{16}$ B\&O president Thomas Swann acknowledged Wheeling as "a most important terminus for this road" due in large part to these inducements, but the $\mathrm{B} \& \mathrm{O}$ board of directors had trouble coming to an agreement. $^{17}$

This decision had a direct affect on Taylor County as it would determine the railroad's alignment. If a route following Wills Creek out of Cumberland or the Cheat River in Preston County northwest to Pittsburgh could not be secured, a terminus at Parkersburg on the Ohio River would lay essentially on a straight line between Baltimore and St. Louis on the Mississippi River. As the northernmost port on the Ohio navigable the year round, Parkersburg would serve B\&O needs as a gateway to western lands. ${ }^{18}$ If $\mathrm{B} \& \mathrm{O}$ directors chose Parkersburg, the main stem would have to pass through the lower Tygart River valley. But political maneuvering, financial problems, and time all

${ }^{14}$ Acts of the Virginia General Assembly (1847), 88; Dilts, The Great Road, 244, 314; B\&O Railroad historian Edward Hungerford described Virginia legislators as "cavalier" and "behaving abominably," The Story of the Baltimore \& Ohio Railroad, volume 1, 241.

${ }^{15}$ Dilts, The Great Road, 240-1, 326-8.

16 American Railroad Journal, 2 August 1851; Dilts, The Great Road, 314, 332.

${ }^{17}$ Address of Thomas Swann on the Parkersburg Road (Baltimore, 28 June 1852), 7.

${ }^{18}$ Ibid, 31-2, 60-1; Stover, History of the Baltimore and Ohio Railroad, 81-2. 
seemed to work against Parkersburg as a choice.

Although not their first preference, $\mathrm{B} \& \mathrm{O}$ investors were somewhat assuaged by knowing that completing their route to Wheeling meant a connection there with the National Road, completed in 1818, and similar links with the Northwestern Turnpike along the way. B\&O stockholders, for the most part, cared little about the route alignment as long as produce of the farms in northern Virginia and Ohio River valley went to Baltimore's port in the most cost-effective manner possible. In the process, they created the rudiments of a Baltimore-based transportation system by intersecting two major highways and joining with railroads in Virginia and Ohio then under construction. ${ }^{19}$

When Virginia granted a new charter to the $\mathrm{B} \& \mathrm{O}$ in 1847 , administrators finally committed to a Wheeling terminus and a route entirely within Virginia. As such, they needed to find the most direct route through the Allegheny Mountains. Main stem alignment options suffered, though, when Monongalia County residents refused to consent to a planned route along the Cheat River and Deckers Creek through Morgantown.

In Morgantown, approximately twenty miles north of Grafton, farmers joined with teamsters and stage coach proprietors to oppose $\mathrm{B} \& \mathrm{O}$ plans to build west from the Cheat River valley in Preston County. They feared that the railroad would eliminate their livelihoods. Many local farmers believed that market prices for feed grains would plummet and that hazardous railroad machinery would cause "untold injury to the people and their stock living along this right-of-way." 20 This resistance, as well as the maneuvers of Thomas S. Haymond, a shrewd Marion County businessman

${ }^{19}$ Twenty Sixth Annual Report of the President and Directors to the Stockholders of the Baltimore and Ohio Rail Road Company (1852), 32 (hereafter Annual Report BORR).

${ }^{20}$ Charles Brinkman, "Early History of Grafton," 3 September 1929; Earl L. Core, The Monongalia Story: A Bicentennial History (Parsons, W. Va.: McClain Printing Company, 1979), 291. 
and politician, caused the $\mathrm{B} \& \mathrm{O}$ to avoid its Cheat River route, and build west out of Preston County, then through Fairmont, Virginia, an extant community. ${ }^{21}$ Haymond, Marion County's delegate to Virginia's General Assembly, sponsored a clause to the 1847 B\&O charter requiring that "the railroad be constructed through the territory of Virginia, [and] shall cross the Tygart Valley river at or within three miles of the mouth of Three Fork creek in the county of Taylor."22

Haymond belonged to an active local political family whose numerous relatives held state, regional, and national offices. After serving as an army sergeant in the War of 1812, Haymond was twice elected to the Virginia House of Delegates and later to the United States House of Representatives. ${ }^{23}$ In addition to their activity in politics, the Haymond family owned expansive tracts of land in Monongalia, Harrison, and Marion counties. Among other holdings, Thomas Haymond owned 628 acres along Booth's Creek, running through southeastern Marion county near the Tygart River. ${ }^{24}$ Knowing that the railroad would raise land values and provide an outlet for valuable timber on his property, Haymond used his position as a state congressman to compel the B\&O Company to build in close proximity to lands otherwise valued at $\$ 1$ per acre. ${ }^{25}$ Haymond's vision and ambitions proved to be key factors in Grafton's birth, for without the legislative clause dictating the B\&O's route, there is no guarantee that the main stem would have followed its presentday route through the town.

${ }^{21}$ Brinkman, "Early History of Grafton," 3 September 1929.

${ }^{22}$ Acts of the Virginia General Assembly (1847), 88.

${ }^{23}$ Samuel T. Wiley, History of Monongalia County, West Virginia (Kingwood, W. Va.: Preston Publishing Company, 1883), 490, 766-7.

${ }^{24}$ Haymond Family papers, correspondence passim, WVRHC; Monongalia County Clerks Office, Monongalia County Land Book 1828 and 1842 to 1848, 1842 entries.

${ }^{25}$ Haymond Family papers, correspondence passim, WVRHC. 
With financing and a final route alignment set in 1849, Thomas Swann could promise his board of directors that "the entire space between Cumberland and the Tygart's Valley River will be in active progress of construction. ${ }^{26}$ However, sufficient numbers of laborers proved difficult to secure. This problem also plagued the Northwestern Turnpike during construction, and provides a clear demonstration of the problem. While renovating the Tygart River bridge at Fetterman in 1849, Northwestern Turnpike superintendent Josiah Wilson observed a troubling phenomenon regarding his work force. Much to his frustration, he found himself supervising a large construction project at a place where an already insufficient labor pool was being drawn off by an even larger construction project. Baltimore \& Ohio Railroad construction attracted able-bodied hands from miles around as they built down the west side of the Allegheny ridge. Wilson repeatedly complained that the $\mathrm{B} \& \mathrm{O}$ purloined his work force by paying wages "ranging from 25 to 35 per cent. higher than I adopted on this road; and the demand from that quarter [the $\mathrm{B} \& \mathrm{O}$ ] continues beyond the supply of the country."27

True to his word, Swann authorized B\&O land purchases beginning in the spring of 1849, and purchasing agent Samuel Cameron acquired a standard 66 foot-wide swath across Taylor County. ${ }^{28}$ The width of two parallel tracks plus space for a raised roadway and drainage ditches determined the size of the right-of-way. Sixty-six feet was also the standard length of a surveyor's chain, greatly simplifying measurements.

Due mainly to activity brought by the nearby Northwestern Turnpike and the high quality of local farm land, the population along the Tygart River and Three Forks Creek had expanded to the

\footnotetext{
${ }^{26}$ Twenty Third Annual Report BORR (1849), 13.

${ }^{27}$ Thirty Fourth Annual Report BPW (1849), 358.

${ }^{28}$ TCCC, Deed Books, 1849-1850, passim; Dilts, The Great Road, 341.
} 
point that the B\&O's purchasing agent had to dicker with several families. In the autumn of 1849 , Cameron purchased easements from John D. and Frances Keener, Isaac M. and Catharine Hall, Lunsford and Hannah Jones, and Mary Armstrong along Three Forks Creek for prices ranging from $\$ 1$ to $\$ 5$ per transaction. ${ }^{29}$ As word spread that agents from the large eastern railroad company were buying mere strips of land without arguing much over the cost, several local landholders raised their prices to boost profits or, perhaps, to serve as compensation for anticipated inconveniences when farmlands would be bisected. In 1849 , easement prices averaged $\$ 20$ per linear acre. ${ }^{30}$

Approaching the Tygart River along Three Forks Creek, Cameron dealt with the Luzadder family, the main landholders at this prime location. Moses and Mathew Luzadder and their families were among the first white settlers in what became Grafton, and the family laid claim to most of the land comprising the east end of the present-day city through tomahawk right. This was a colloquial term for squatting, or occupying land not granted by government charter. ${ }^{31}$

The Luzadder family could trace their lineage to Sephardic traders of the Mediterranean region. ${ }^{32}$ Aaron Luzadder, II, a first-generation American born in 1735, moved about a good deal as an adult. After changing his name from the traditional Lousada, leaving his native New Jersey, and serving as a sergeant in the American Revolution, he located in Greene County, Pennsylvania,

${ }^{29}$ TCCC, Deed Book 2, 187, 188, 190, and 193; By definition, a right-of-way is an easement, and ownership of the land in question may or may not be relevant. According to Black's Law Dictionary, Fifth Edition, an easement is "a right of use over the property of another." The B\&O restricted public access to its rights-of-way for safety reasons, not exclusively as a question of proprietary ownership.

${ }^{30}$ TCCC, Deed Book 2, 189, 192, 234-5, and passim.

${ }^{31}$ Joseph Doddridge, Notes on the Settlement and Indian Wars (Pittsburgh, Pa.: John S. Ritenour and William T. Lindsey, 1912), 81 for a detailed description of tomahawk land claims.

${ }^{32}$ The family name often is spelled Luzader or Luzzader in records. 
with his wife, Sarah Cole Luzadder of Maryland. Fetterman on the Northwestern Turnpike was his next stop, and he finally moved to Monongalia County. While living along the Tygart River, Aaron Luzadder, III, was born in 1787 as one of thirteen siblings. Aaron remained near Fetterman after his parents moved and married Martha Vincent, establishing the Luzadder family in Taylor County. ${ }^{33}$

As a practical matter, the Luzadders could trade in land as a most bountiful and potentially lucrative commercial medium. When $\mathrm{B} \& \mathrm{O}$ representatives began purchasing their right-of-way in 1849 , the Luzadders assumed the ostensible role of land brokers. They realized that a railroad would bring homesteaders who would also need land.

In November 1849, Mathew and Matilda Luzadder sold the first of several plots to the B\&O, a 66-foot-wide right-of-way through their property along Three Forks Creek for $\$ 5$ “in hand." ${ }^{34}$ At the same time, Moses and Christina Luzadder sold an extensive right-of-way through their land along Three Forks Creek for $\$ 20 .{ }^{35}$ Within the following four years, Moses and Christina Luzadder would sell substantial parcels of land around Grafton for the Northwestern Virginia Railroad as well.

As right-of-way purchases continued along the north bank of the Tygart west of Three Forks Creek, Sarah Fetterman, the largest land holder around the village then known as Valley Bridge, sold parts of her land. Granddaughter of Baron de Bulan, Austrian ambassador to the United States, she married Washington W. Fetterman of Allegheny County, Pennsylvania. Over time, Washington Fetterman had accrued over 2,600 acres near the turnpike crossing of the Tygart River and

\footnotetext{
${ }^{33}$ A History of Taylor County, West Virginia, 300.

34 TCCC, Deed Book 2, 185.

35 Ibid, 191.
} 
approximately 4,000 acres of land in northern Virginia. ${ }^{36}$ After his death while visiting Philadelphia in 1838 , Sarah was compelled to satisfy debts and county tax assessments. ${ }^{37}$ In 1845 , she made $\$ 2,476$ selling one plot of 160 acres and another of 1,000 prime acres along the river for that purpose. ${ }^{38}$ Like the Luzadders, she later sold numerous plots to migrants arriving by railroad.

Generally, as Cameron secured the B\&O's right-of-way, he tended to pay as much to the various land owners for a 66 -foot-wide easement as if land had been purchased by the acre, but those prices were not consistent. For example, a right-of-way along Sarah Fetterman's 2,526 acre riverside land, "known as the Valley Bridge property," sold for $\$ 1$ during January of $1850 .{ }^{39}$ County officials had valued that same property at $\$ 1$ per acre, save for two plots with an added value of $\$ 50$ due to existing buildings. ${ }^{40}$ She owned land along the east bank of the Tygart River and north bank of Three Forks Creek, and the county court assessed the majority of Fetterman's property at $\$ 1$ to $\$ 5$ per acre, with one three-quarter acre plot along the Tygart containing a sizable coal seam valued at $\$ 15 .^{41}$

By rights, Fetterman could have asked many times more from the $\mathrm{B} \& \mathrm{O}$ for their intrusion upon her property holdings. Unlike Fetterman, though, other local land holders were not inclined to pass up an opportunity for sure profits rather than risk long-term speculation. Edward and Catharine Henderson sold the Baltimore \& Ohio Company a standard 66-foot right-of-way for $\$ 15$

${ }^{36}$ TCCC, Land Book, 1848-1855, 1848 entries; John W. Jordan, editor, A Century and a Half of Pittsburgh and Her People, volume 4 (Pittsburgh: The Lewis Publishing Company, 1908), 72-3.

${ }^{37}$ Jordan, A Century and a Half of Pittsburgh and Her People, volume 4, 72.

${ }^{38}$ TCCC Land Book, 1848-1855, 1851 entries.

39 TCCC Deed Book 2, 194.

${ }^{40}$ TCCC Land Book, 1848-55, 1848 entries.

${ }^{41}$ Ibid, 1851 entries. 
in April 1850, being bounded on both sides by Sarah Fetterman's land previously valued at about $\$ 1$ per acre. ${ }^{42}$ Arthur and Frances Fitch of Preston County improved on that by selling a piece of land roughly the same size in January of 1850 . Their land along the Tygart, again bounded by Sarah Fetterman's $\$ 1$ per acre property, sold for $\$ 25 .^{43}$

During the spring of $1850, \mathrm{~B} \& \mathrm{O}$ officials prepared for another season of construction to complete the main stem. Nearly 5,000 men and 1,250 horses stood ready to complete various sections between the Tygart River and Wheeling. ${ }^{44}$ By December of 1850 , all construction contracts had been awarded for the main stem to Wheeling, and $\mathrm{B} \& \mathrm{O}$ administrators were finally tackling the last portion of road construction. ${ }^{45}$ The main stem from the Cheat River to the turnpike at Fetterman had already been divided into 58 sections for construction, each one 5,343.7 feet long. Each contracted crew would build one section. ${ }^{46}$

But problems still plagued the venture. Construction of the main stem halted on numerous occasions due to lack of funds and labor discord. Often, workers would not be paid for many weeks when the $\mathrm{B} \& \mathrm{O}$ suffered under any one of several financial crises. Employees who had been promised good wages for difficult and dangerous work rebelled against their treatment through shortterm work stoppages when group grievances fell upon deaf ears. ${ }^{47}$

In an effort to mollify discord, $\mathrm{B} \& \mathrm{O}$ administrators granted a pay increase for workers,

${ }^{42}$ TCCC Deed Book 2, 233-4.

${ }^{43}$ Ibid, 234-5.

44 "The Baltimore and Ohio Railroad.—The Tunnel," American Railway Times 2, (20 June 1850): 2; Stover, History of the Baltimore and Ohio Railroad, 71.

${ }^{45}$ Twenty Sixth Annual Report BORR (1852), 65.

${ }^{46}$ Twenty Third Annual Report BORR (1849), 36.

${ }^{47}$ Dilts, The Great Road, 136-9, 269-70, 358-60. 


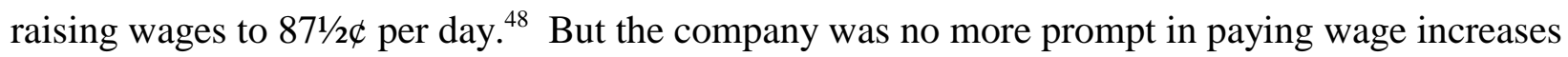
than it had been for regular earnings. A strike resulted in March 1850 among workers building a particularly difficult section of road along the upper Cheat River and the Kingwood Tunnel in Preston County. Some strikers went so far as to shoot at workers who would not join the pickets, and the $\mathrm{B} \& \mathrm{O}$ soon assembled a private police force which quelled the riots and work interruptions. Continuing turmoil among workers compelled their presence for the entire time of construction on the main stem. ${ }^{49}$

These problems, combined with a small indigenous population, added to a shortage of workers, slowing completion of the road. When B\&O flyers and advertisements circulated soliciting workers to complete the main stem, Irish laborers, some of whom had worked on previous sections of the railroad and others who had only recently arrived in America, began to gather in Cumberland. ${ }^{50}$ By the summer of 1850 , agents for chief engineer Benjamin Latrobe, Jr., had secured an adequate work force for the project, but excessive alcohol use among his workers all but nullified their productivity. ${ }^{51}$ In addition, often "laborers would no sooner be transported to the railhead than they would disappear into the forests, intent on cutting farms from the wilderness." 52 Thomas Swann worried that until a reliable work force could be secured, the main stem could not be extended into the Tygart valley and beyond. ${ }^{53}$ Latrobe was nonetheless confident that, if the labor question could

${ }^{48}$ Ibid, 358.

${ }^{49}$ Ibid, 358-9.

${ }^{50}$ Ibid, 345.

${ }^{51}$ Baltimore \& Ohio Rail Road Company Minute Book "F” (1850), 334.

${ }^{52}$ Dennis M. Zembala, Historic American Engineering Record Grafton Machine Shop and Foundry Report (HAER WV-10, United States Park Service, 1975), 16.

${ }^{53}$ Twenty Fourth Annual Report BORR (1850), 13. 
be settled and construction continued as planned, the railroad would meet the turnpike at Fetterman by the spring of $1852 . .^{54}$

Factional differences among the Irish continued, however, stemming from ancient religious strife and exacerbating labor problems. Occasionally, riots occurred when contractors failed to pay workers on time and in full. ${ }^{55}$ Such difficulties were not unique to the B\&O's situation and came as little surprise to $\mathrm{B} \& \mathrm{O}$ administrators. Indeed, many people on both sides of the Atlantic harboring prejudices against the Irish would have accepted and concurred with Englishman Morris Birkbeck's observations regarding Irish railroad workers in the United States:

The low Irish, as they are called even here, too often continue in their old habit of whiskey drinking: and, as in London, they fill the lowest departments of labour in the manufactures, or serve the bricklayers, \&c. They are rude and abandoned, with ample means of comfort and independence; such is the effect of habitual degredation of character. The low Irish and the freed negro, stand at nearly the same degree on the moral scale, being depressed equally by early associations. ${ }^{56}$

But not everyone shared those sentiments about Irish laborers. Fetterman native William Robinson, for example, worked with Irishmen at McGuire's Tunnel in eastern Preston County. He wrote amicably in a letter to his sister that "the Irish all appear very clever. I think I will have some friends amon[g]st them." ${ }^{57}$ Indeed, a significant number of Irish railroad laborers eventually settled in and around Grafton, contributing to its initial population growth.

In addition to labor difficulties, other factors such as epidemics slowed production. Ironically, railroads brought with them not only convenience and commerce, but the same health

\footnotetext{
${ }^{54} \mathrm{Ibid}, 15$.

${ }^{55}$ Dilts, The Great Road, 345.

${ }^{56}$ Birkbeck, 41.

${ }^{57}$ Robinson Family Papers, William J. Robinson to Miss H.M. Robinson, 12 September 1857, WVRHC.
} 
problems for local residents along the construction route as those visited upon Native Americans when Europeans first arrived in North America. Smallpox seemed to follow railroad labor gangs like a nefarious shadow, and often spread quickly with the close proximity of workers to town residents as they intermingled to eat and sleep. Local historian Charles Brinkman described Grafton during the 1850s as lacking in sanitation with "piles of filth and refuse everywhere that bred all kinds of germs and vermin. ${ }^{158}$ Susan Robinson, for example, urged her father to return to their home in New Milton, Virginia, when she learned that he had traveled to Grafton in 1852 when the town was little more than a construction camp. Her concern arose from news that an outbreak of smallpox had occurred there and at Fetterman, also under $\mathrm{B} \& \mathrm{O}$ construction. ${ }^{59}$

Construction of the main stem contributed to a transportation system which already connected Baltimore, Washington, D.C., and Philadelphia by the early 1850s. B\&O workers were in the process of overcoming the Alleghenies en route to the Ohio River valley, extending the railroad's reach. Boosters advocating community development and industry in western Virginia awaited "this splendid avenue to the West" from the first trials in Baltimore using horse-drawn rail cars. ${ }^{60}$ To the $\mathrm{B} \& \mathrm{O}$ directors, reaching the Ohio valley was the "paramount object," not only of their efforts, but of Maryland, Virginia, and Baltimore authorities, "and of those public spirited individuals by whom the enterprise was originally projected." ${ }^{\circ 1}$ Many $\mathrm{B} \& \mathrm{O}$ officials already envisioned by 1850 an expansive, near nation-wide system, with Cincinnati, St. Louis, and Chicago as longer-term goals after the Baltimore to Ohio River main stem became operational.

\footnotetext{
${ }^{58}$ Brinkman, "Early History of Grafton,” 5 September 1929.

${ }^{59}$ Robinson papers, Susan Robinson to father, letter 22, 18 February 1852, WVRHC.

${ }^{60}$ Wheeling Gazette, 29 May 1830.

${ }^{61}$ Eighteenth Annual Report BORR (1844), 28.
} 
In building the railroad, minimizing the effect of gravity, accommodating technical limitations, and crossing water courses required considered calculations and construction. The mission of railroad surveying crews was to seek out terrain nearest to level. In the Allegheny Mountains, that charge proved essentially impossible. But in Taylor County, Three Forks Creek and its confluence with the Tygart River provided advantages both for routing a rail line and for permanent passenger, freight, and service facilities in a position and on topography suitable to railroading needs.

As terrain eased west of the Cheat River and the Tray Run viaduct, sagging spirits of laborers and investors alike revitalized and confidence in reaching the Ohio valley rekindled. In 1850, clearing and grading the right-of-way had been nearly completed, excavation of the daunting Kingwood Tunnel through Cheat Mountain was under way, and over 2,000 tons of iron rails had arrived from the London forges of Thompson and Foreman, exactly on schedule, at Locust Point, the $\mathrm{B} \& \mathrm{O}$ ocean shipping wharf at Baltimore.$^{62} \mathrm{~B} \& \mathrm{O}$ administrators had waited over two decades for the main stem to begin operations, and fiscal shortages meant that choices would have to be made. Major funding went to such features as viaducts and tunnels, with many lesser service facilities and passenger depots built expediently.

In June 1850, main stem work crews had reached Irontown, so named for the small iron foundry erected there in the early 1820 s. A boom town in its own time, Irontown had dozens of smelting furnaces with jobs to support most of the families around the town in the 1840s. Although the Baltimore \& Ohio Railroad followed the Three Forks Creek through Irontown in 1850, it did not

62 "The Baltimore and Ohio Railroad.-The Tunnel," American Railway Times 2, (20 June 1850): 2; Baltimore \& Ohio Rail Road Company Minute Book "F" (1850), 427. 
prove an important point on the main stem. Inconvenient to the Northwestern Turnpike in the 1830s, local reserves of moderate- to high-grade iron ore had diminished in quantity and value by the time the railroad arrived. Despite the arrival of the $\mathrm{B} \& \mathrm{O}$, the iron industry could no longer continue as a successful concern there. ${ }^{63}$ Too far removed from the turnpike to make production cost effective at an early stage, Irontown already was undergoing a decline of resources when railroad technology emerged, leading to the community's eventual decline.

Approximately three miles south of Irontown lay the village of Thornton. Here, the B\&O met Three Forks Creek for the first time. The hamlet took its name from Anthony Y.D. Thorn, a tavern owner along the Northwestern Turnpike. Born in September 1804, "Doc" Thorn, so known because of his informal medical and dental practice, also owned a small maple sugar camp and a water-powered combination gristmill and sawmill. Acclaimed as a fine cabinet maker, Thorn also made coffins for departed local citizens. Until the B\&O's arrival, Thorn received supplies and commercial goods over the turnpike from Winchester. ${ }^{64}$ Although prosperity from the railroad lasted only until the Civil War, when Grafton came to dominate the county, Thorn may have been pleased with his location next to the $\mathrm{B} \& \mathrm{O}$ main stem as being good for business. However, he twice suffered setbacks when sparks from passing locomotives burned down his home and business. ${ }^{65}$

Over 5,500 feet of tracks made up Thornton's rail yards for local light industries and a small freight depot to supply businesses and residents. The B\&O used heavy grade " $\mathrm{T}$ " rails rather than lighter or lower quality rails, representing state-of-the-art railroad technology and indicating the

\footnotetext{
${ }^{63}$ A History of Taylor County, West Virginia, 18.

${ }^{64}$ A History of Taylor County, West Virginia, 22, 508.

${ }^{65}$ Ibid, 508.
} 
importance company directors assigned to main stem commerce. ${ }^{66}$ " $\mathrm{T}$ " rails were solid iron rails which resembled an inverted "T" with a broad base if viewed in cross-section. "Heavy-duty" referred to rails which weighed 58 pounds per linear yard in $1850 .{ }^{67}$ Main stem service facilities, even if temporary, needed heavy rails to carry increasingly heavier locomotives and cars. By September of 1852, with the main stem not quite complete, 36 passengers had used the Thornton station. ${ }^{68}$ By $1855,1,564$ passengers, traveling over 68,000 miles, passed through the doors of Thornton's depot. ${ }^{69}$ Baltimore \& Ohio planners envisioned freight transport as earning the highest profits and, indeed, had built the railroad to carry the produce of western lands. However, passenger travel initially drew the greatest interest from the public. Traveling overland faster than a running horse attracted thousands of rail passengers even before completion of the main stem.

As construction crews followed Three Forks Creek and reached the future site of Grafton, local topography made clear the area's advantages. Alluvial plains of the creek and Tygart River confluence provided abundant space for right-of-way and side tracks. Gently sloping grades along these two water courses also meant that no tunneling would have to be done within Taylor County. Because the main stem would follow the north bank of the Tygart, only relatively minor bridging would be needed until reaching the Monongahela River above Fairmont, another key point for B\&O operations. Wheeling's city council had agreed to purchase 5,000 shares of company stock when the main stem reached Fairmont, a sum of $\$ 500,000 .^{70}$

${ }^{66}$ Twenty Ninth Annual Report BORR (1855), 64.

${ }^{67}$ Baltimore \& Ohio Rail Road Company Minute Book "F" (1850), 432.

${ }^{68}$ Twenty Sixth Annual Report BORR (1852), Table L.

${ }^{69}$ Thirtieth Annual Report BORR (1856), 42.

${ }^{70}$ Twenty Third Annual Report BORR (1849), "Contract Between the City of Wheeling and the Baltimore and Ohio Railroad Company," 3. 
At Grafton, or the village first called Parkersburg Junction on railroad timetables, B\&O engineers selected land for Northwestern Virginia Railroad yards and engine service shops. B\&O planners had envisioned a "Northwestern Branch" between Parkersburg and the Tygart River as early as 1850 , and had ordered a survey of proposed alignments for the Northwestern Virginia Railroad by $1851 .^{71}$ Being subject to the ravages of high water, the site proved troublesome to the NVRR's new chief engineer, Benjamin H. Latrobe, $\mathrm{Jr}^{72}$ Baltimore \& Ohio planners were aware of the Tygart's tendency to flood from local residents and Northwestern Turnpike Company reports. But given the topography of the area, a level plain between a flood-prone river and precipitous hills was the best they could hope for. Latrobe grew to anticipate such problems in the Allegheny Mountains where occupying open level ground required some concessions to the elements. Even before the main stem was fully operational between Wheeling and Cumberland, flooding of the Tygart River and its tributaries wreaked havoc with $\mathrm{B} \& \mathrm{O}$ operations and construction of the Northwestern Virginia Railroad. Heavy rains hastened winter's snow melt in April 1852, causing torrents to sweep across open lowlands. Latrobe had directed that tracks and bridges be built to exacting standards, helping them to escape serious damage, but massive landslides halted construction for weeks. ${ }^{73}$ Anticipating annual spring floods in 1853, B\&O president Thomas Swann prepared stockholders for continuing expenses to repair damage. "An increased force is indispensable to be kept constantly

${ }^{71}$ Twenty Fifth Annual Report BORR (1851), 12-3.

${ }^{72} \mathrm{~B} \& \mathrm{O}$ administrators planned to incorporate as many branch lines for the main stem as possible, including the Pittsburgh \& Connellsville between Cumberland and Pittsburgh, and the Northwestern Virginia Railroad. In order to best coordinate construction and maintain consistency in design and continuity of traffic flow, the B\&O's chief engineer, Benjamin Latrobe, became the chief engineer for these adjunct projects. Refer to Dilts, The Great Road, 322,444 , for a more complete examination.

${ }^{73}$ Ibid, 372. 
on hand to remove slips and clear the way for the daily passage of the trains," he reported. ${ }^{74}$ Two years later, spring freshets caused an estimated $\$ 150,000$ in damage to the main stem, sidings, and structures along the Tygart and Monongahela rivers. ${ }^{75}$

By the fall of 1850, B\&O construction crews had reached Fetterman and the Northwestern Turnpike. ${ }^{76}$ In preparing for temporary passenger and freight depots, engine facilities, rail yards, and associated buildings at Fetterman, the Baltimore \& Ohio Company bought land largely from Sarah Fetterman. A $\$ 3,594$ five-stall locomotive service shop there, completed in 1853, occupied land previously used by local residents as a baseball field. ${ }^{77}$ The B\&O also purchased lot number 23 with 120 feet of frontage on Baltimore Street at the corner of Cameron Street from Samuel Cameron. Originally from Jefferson County, Virginia, Cameron had purchased lot 23 from Sarah Fetterman on 19 February 1851 for $\$ 125$ "in full."78 The land changed hands on 30 April 1853 at a cost of $\$ 450 .^{79}$ After some delays, Fetterman's combination freight and passenger station was completed by the autumn of 1855 at a cost of $\$ 630 .^{80}$

Even before Fetterman's passenger station had been completed, travelers used local roads and the Northwestern Turnpike to reach the Baltimore \& Ohio. Swann observed in 1850, that using

${ }^{74}$ Remarks of Thomas Swann, Esquire, Upon His Resigning the Presidency of the Baltimore and Ohio Rail Road Company (Baltimore: James Lucas, 1853), 5.

75 Twenty Ninth Annual Report BORR (1855), 20.

${ }^{76}$ Dilts, The Great Road, 359.

${ }^{77}$ Brinkman, "Early History of Grafton," 4 September 1929; Twenty Seventh Annual Report BORR (1853), 23.

78 TCCC, Deed Book 2, 534.

79 TCCC, Deed Book 3, 131.

${ }^{80}$ Twenty Ninth Annual Report BORR (1855), 71. 
the turnpike, travel time from Parkersburg to Baltimore "would not exceed 29 hours." ${ }^{" 11}$ Indeed, in coaxing his board of directors to accept the compromise Wheeling route, Swann noted that the main stem would draw commerce from the turnpike. Swann exclaimed that "the State of Virginia has made large appropriations for macadamizing this great thoroughfare [the Northwestern Turnpike], - and it cannot fail to prove a most important feeder to the Road [the B\&O], even after it shall have been completed to the City of Wheeling." ${ }^{~} 2$ Swann further reported that several local roads connecting to the turnpike could be relied upon for commercial traffic, but Northwestern Turnpike directors, understandably, dreaded that railroads would soon ruin their business. ${ }^{83}$

Proceeding west of the Northwestern Turnpike, $\mathrm{B} \& \mathrm{O}$ work crews entered Fairmont on 22 June $1852 .{ }^{84}$ Laying at the headwaters of the Monongahela, a navigable river to Pittsburgh and the Ohio valley, Fairmont offered the $\mathrm{B} \& \mathrm{O}$ trade from numerous farms and coal seams in the area, and a town with existing trades in copper and machined products eager to have them. ${ }^{85}$

With the main stem open to Fairmont, $\mathrm{B} \& \mathrm{O}$ workers began construction on facilities in towns along the route. An influx of passengers led to a growth spurt at Fetterman which, in turn, drew in some area residents. Henry Mahaney, a tavern owner at Pruntytown, abandoned his Main

${ }^{81}$ Twenty Fourth Annual Report BORR (1850), 15.

${ }^{82}$ Ibid; Macadamizing, a process of road building named for the Scottish engineer and inventor John Loudon McAdam, entailed a six- to ten-inch-thick layer of three- to six-inchdiameter broken stones laid upon a minimal foundation. McAdam believed that a lesser roadbed would be needed than the complicated system of progressively smaller, compacted stones layered on large rocks traditionally preferred, if the road's surface could be made waterproof and solid to deter abrasion. See Daniel L. Schodek, Landmarks in American Civil Engineering (Cambridge: M.I.T. Press, 1988), 29-30 for a review of road building techniques contemporary to the early nineteenth century.

${ }^{83}$ Thirty Seventh Annual Report BPW (1852-53), 140.

${ }^{84}$ Ibid.

${ }^{85}$ Dilts, The Great Road, 374. 
Street establishment in 1853, moving away from the turnpike. The 34-year-old Mahaney relocated his wife, three children, and one slave to Fetterman to be near the railroad. ${ }^{86}$ James K. Smith also moved from Pruntytown and established the first new store at Fetterman since the B\&O's arrival. A wood-frame structure at the east end of the turnpike bridge served as Smith's general store and family home. With little hard cash then available, patrons bartered store merchandise for pelts and processed hides, ginseng roots, and flax. ${ }^{87}$ The record of Virginia's western frontier shows that natural resources such as flax, ginseng, and berries were regularly gathered for barter or sale as part of family and community enterprise. Treated deer skins, for example, could garner 24 cents apiece, mink skins sold for 75 cents, red fox for $\$ 1$, and otter hides for $\$ 1.50$ before shipment to eastern markets in the $1850 \mathrm{~s}^{88}$

Smith followed the example of his entrepreneurial father, Abraham Smith. Born in Williamsport, Harrison County, in approximately 1825, James Smith received his education at Rector College in Pruntytown before studying law in Clarksburg under his brother-in-law, Burton Despard. After briefly practicing law, Smith earnestly pursued business. He owned several farms with tenant managers throughout Taylor County and started general stores, first with his brother Marshall in Pruntytown, and on his own in 1850 at Fetterman. ${ }^{89}$ With his various contacts, one term

${ }^{86}$ A History of Taylor County, West Virginia, 15; United States Bureau of the Census, 1850 manuscript census records for Taylor County, Virginia, household 741, where the name is spelled Mahany.

${ }^{87}$ Brinkman, "Early History of Grafton," 3 September 1929; for an examination of frontier barter economy see Mary Beth Pudup, "The Boundaries of Class in Preindustrial Appalachia," Journal of Historical Geography, 15 (April 1989): 139-43.

${ }^{88}$ Brinkman, "History of Taylor County," 10 May 1939.

${ }^{89}$ James K. Smith obituary, Grafton Sentinel, 24 May 1901; Biographical and Portrait Cyclopedia of Taylor County, 7-8; Smith's exact date of birth can not be determined from existing records. 
as a representative to the Virginia House of Delegates, and head for business, the Baltimore \& Ohio Company hired Smith as the Fetterman station agent in $1852 .{ }^{90}$ At $\$ 58.35$ per month, Smith received a good wage for the time, being about double the annual wages of an average American. He managed the tiny station and remained loyal to his adopted home of Fetterman, even after many of his friends and business associates relocated. ${ }^{91}$

Although a minor depot on the main stem, the Fetterman station accounted for $80,728.5$ passenger miles in 1852 , handling mainly short distance travel with the vast majority of passengers riding the one mile of rails between Fetterman and Grafton Junction, as the village of Grafton was then known on B\&O timetables. ${ }^{92}$ Fettermanites saw approximately three times more east-bound passenger traffic than west-bound as 1,727 travelers passed through its station that year. ${ }^{93}$ Observed B\&O president Thomas Swann, "the first day of October, 1852, found the Road opened for use to Fairmont on the Monongahela River for Merchandise, and to Fetterman only for Passengers, with a trade and travel almost entirely of a local character-and that, such as only a comparative wilderness could afford." 94 Small growing communities like Fetterman, therefore, did serve to increase traffic for the $\mathrm{B} \& \mathrm{O}$, even if only in small increments.

$\mathrm{B} \& \mathrm{O}$ administrators also actively sought all likely forms of commerce, affecting local businesses and employment levels. This process began virtually as soon as tracks could convey

${ }^{90}$ Biographical and Portrait Cyclopedia of Taylor County, 8.

${ }^{91}$ List of Officers and Employees in the Service of the Baltimore \& Ohio R. Road Company (Baltimore: James Lucas and Son, 1855), 3; James K. Smith obituary, Grafton Sentinel, 24 May 1901.

92 Twenty Sixth Annual Report BORR (1852), Table L.

${ }^{93}$ Ibid, appendix chart.

${ }^{94}$ Twenty Seventh Annual Report BORR (1853), 19. 
trains. In 1851, the main stem carried 15,300 tons of pig iron and iron ore out of northwestern Virginia. ${ }^{95} \mathrm{~B} \& \mathrm{O}$ accountants estimated that by the end of 1852 , the coal trade would reap $\$ 462,500$ in revenue on the as-yet-incomplete main stem. ${ }^{96}$ In December of 1852 , wishing to expand the railroad's investment in carrying such commodities, the B\&O's new president William G. Harrison agreed to secure a $\$ 2,500,000$ loan dedicated to capital improvement. ${ }^{97}$ In addition to larger locomotives for heavy, bulky loads, B\&O planners provided better storage and handling facilities for their ocean shipping terminal at Locust Point in Baltimore, as well as loading facilities at coal and iron production points all along the line..$^{8}$ In Taylor County, Simpson, Flemington, and Wendel on the Parkersburg Branch and various places between Valley Falls and Fairmont on the main stem, received improved coal handling facilities between 1853 and $1857 .{ }^{99}$

Baltimore \& Ohio administrators had already planned for 47 additional locomotives, 1,650 new freight cars, and 42 passenger cars to manage a system-wide increase in traffic by $1852 . .^{100}$ Seven heavy freight engines would be assigned to the Fetterman depot for haulage and to assist trains in climbing and descending Cheat Mountain. At least ten freight trains daily would be departing Fetterman for the eight-day trip to Baltimore and back. Heavy- and medium-duty freight engines worked dauntlessly against precipitous grades of the Allegheny ridge to ship materials east and return with commercial goods. ${ }^{101}$ The $\mathrm{B} \& \mathrm{O}$ anticipated that 350 livestock cars alone would be needed for

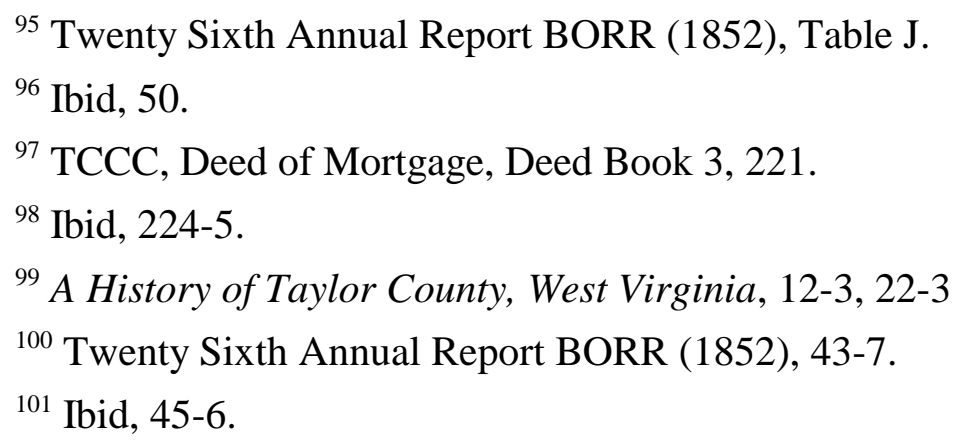


eastbound traffic from Wheeling, with the Fetterman station accounting for a dozen weekly. ${ }^{102}$

Early in 1852, negotiations in Wheeling between city and B\&O officials over siting the railroad depot concluded. It would lay on the north bank of Wheeling Creek at its mouth on the Ohio River in the city. In fact, the southern-most end of the freight platform extended onto Wheeling Creek on an iron bridge. ${ }^{103}$ As dusk settled over Wheeling on New Year's Day in 1853, the first train over the main stem from Baltimore arrived to complete the line. ${ }^{104}$ Connection with the National Road at Wheeling may not have been the preferred Ohio River terminus for the B\&O, and depending on the circumstances, $\mathrm{B} \& \mathrm{O}$ planners generally viewed turnpikes alternatively as assets and liabilities. But it and similar contact with roads and turnpikes along the way did make a regional transportation system capable of taking in commerce from Ohio, southern and western Pennsylvania, Maryland, and northern Virginia, while hotly competing with the B\&O's arch rival, the Pennsylvania Railroad.

By 1854, two years after the main stem opened, Fetterman's transitional facilities included just over 11,000 feet of heavy- and light-duty rails for marshaling yards, industrial sidings, and shortterm train storage. This may seem an inefficient use of capital, but safe and cost effective operation made this allocation of resources essential, as anything less substantial would be inadequate to meet daily use. ${ }^{105}$ In addition, expected commerce from the Northwestern Turnpike made freight and passenger depots fundamental.

Operation of nineteenth century railroads required water supplies to be located at least every 20 to 30 miles for locomotives in mountainous areas. Coaling stations, or stocks of firewood for the
102 Ibid, 46.
${ }^{103}$ Ibid, 376-7.
${ }^{104}$ Ibid, 380.
105 Ibid, 64. 
numerous locomotives still burning wood before the Civil War, had to be located at approximately 80 to 100 mile intervals for a process that could require an overnight layover. Steam locomotives also required labor-intensive maintenance necessitating service facilities about every 100 miles under the rough conditions in the Allegheny Mountains. ${ }^{106}$ Grafton Junction met all those requirements far better than did the cramped turnpike village of Fetterman, while simultaneously offering level ground for Northwestern Virginia and, subsequently, Baltimore \& Ohio railroad facilities. Situated between coaling and maintenance stations at Rowlesburg and Fairmont, the town of Grafton lay at a convenient interval along the main stem.

The Northwestern Virginia Railroad

The clamor for railroads from some communities by the late 1840s had exceeded the wave of enthusiasm for turnpikes in the two previous decades. Railroads became the primary investment for internal improvement boosters. In Wood County on the Ohio River, residents saw Wheeling chosen as the B\&O's western terminus. As a result, a number of Parkersburg financiers revisited their intentions to incorporate a railroad company connecting Baltimore with Cincinnati by way of Parkersburg as B\&O directors had originally planned. They organized a committee entreating the $\mathrm{B} \& \mathrm{O}$ to pursue their initial interest in a Parkersburg route to the Ohio River. B\&O agents had surveyed to Parkersburg previously, and such a route would parallel the Northwestern Turnpike.

With florid promises printed in newspapers and expounded in popular publications by politicians since the 1830s, Parkersburg railroad boosters saw their opportunity. They drew

${ }^{106}$ For a more complete survey of generally accepted American railroading procedures for watering and fueling see Robert Selph Henry, This Fascinating Rail Road Business (New York: Bobbs-Merrill Company, 1946), 145-9, 291. 
inspiration from rhetoric in some of the best known railroad journals of the time, such as these words in the December 1850 American Railway Times:

We know of no material improvement better calculated to unite the discordant elements of civilization, to bring labor and capital into their true position, or rather even to secure the entire dominion of the former, than railroads. By them the distant are brought near, the agriculturist heretofore separated from is united to the manufacturer, and commerce instead of as formerly preying upon both, becomes the medium of union, the bond of connection which is destined never to be severed. ${ }^{107}$

Through the efforts of Parkersburg and Baltimore boosters, Virginia's General Assembly chartered the Northwestern Virginia Railroad Company on 14 February 1851, but this proved to be a difficult birth. $^{108}$

Richmond and eastern Virginia legislators, not wishing to give Baltimore a trade advantage, endeavored to curtail use of a Parkersburg branch road as long as possible. A key clause in the Northwestern Virginia Railroad charter read that the road "shall not be used for the transportation of freight or passengers, (except persons engaged in and materials for the construction thereof,) until twelve months after the Baltimore and Ohio railroad company shall have completed their railroad from Cumberland in the state of Maryland to the terminus thereof in the city of Wheeling." 109 The Virginia legislature, dominated by eastern representatives, also reserved the right to nullify the NVRR charter if they used their line before being thoroughly inspected and certified by the Board of Public Works regardless of the completion date of the B\&O. ${ }^{110}$

Notwithstanding legislative restrictions, the Northwestern Virginia Railroad still required

107 “Benefits of Railroads,” American Railway Times 2 (5 December 1850): 1.

${ }^{108}$ Acts of the Virginia General Assembly (1850-51), 69-70.

109 Ibid, 70.

${ }^{110} \mathrm{Ibid}$; for more information on competing railroads see Dilts, The Great Road, 366-7. 
financing for construction and operation. Eugene Levassor, Parkersburg businessman and staunch supporter of a Parkersburg line, relentlessly promoted railroads both publicly and in private correspondence. Eager to tap into a national internal improvement system, many Wood County investors and businessmen began organizing a special interest group to lobby Baltimore \& Ohio administrators, encouraging them to pursue their initial interest in a Parkersburg route to the Ohio River. In an 1851 letter from a close friend, Levassor read with, no doubt, a mix of chagrin and hope, "our town [Parkersburg] as usual, does not offer any great attractions, but when our Rail Road is completed, we may expect activity and life enough here, to give you a pretty good opinion of the place." 111

Anticipation must have been palpable in Wood County when $\mathrm{B} \& \mathrm{O}$ administrators began serious discussions of a Parkersburg branch. On an inspection trip to Wood County in May of 1851, a delegation from the $\mathrm{B} \& \mathrm{O}$, including Swann and Latrobe, saw impressive enthusiasm among the citizenry for a railroad. In corresponding with Levassor, a friend named Smithe observed that Swann and Latrobe "expressed themselves highly pleased with the prospect of having the road completed to this place to connect with their road at three fork about 120 miles east of this." ${ }^{112}$

Interest by the Baltimore \& Ohio board of directors, as well as these visits from Swann and Latrobe, must have inspired the citizens of Parkersburg. By July 1851, city administrators had purchased \$50,000 in Northwestern Virginia Railroad stock. Private subscriptions pledged at Parkersburg totaled an additional $\$ 100,000$. E.C. Phelps, a friend of Levassor, had personally pledged $\$ 5,000$ and determined to make good on the Parkersburg Branch "if it takes my shirt." 113

${ }^{111}$ Eugene Levassor collection, B. Smithe to Levassor, 27 May 1851, WVRHC. ${ }^{112}$ Ibid.

${ }^{113}$ Eugene Levassor collection, E.C. Phelps to Levassor, 1 July 1851, WVRHC. 
He criticized the "moneyed men" of Parkersburg as too timorous and conservative to be involved in such ventures, particularly after Phelps had committed such a quantity of personal funds that he had to ask Levassor for a $\$ 2,000$ loan to tide him over for the coming year. ${ }^{114}$ Individual subscribers from various locations had pledged approximately $\$ 500,000$ for stock, the city of Baltimore subscribed for three times that amount, and $\$ 1,000,000$ came from the Baltimore \& Ohio Company to total about $\$ 3,000,000$ for construction. ${ }^{115}$ This was a tangible representation of boosterism, an almost doctrinal foresightedness and confident anticipation that opportunity and hard work naturally lead to personal and communal success. ${ }^{116}$ Based on that faith, the NVRR had made arrangements to purchase iron rails on credit and was staving off payment for road grading, masonry work, and bridging until one year after the road had been completed with a view toward profitability at that time. ${ }^{117}$

In 1851, Latrobe selected the Tygart River flood plains for the substantial Northwestern Virginia Railroad shops and roundhouse. In that same year, he accepted the position of chief engineer for the NVRR to lay out a route from Grafton Junction to Parkersburg, marking the importance that $\mathrm{B} \& \mathrm{O}$ planners placed on a Parkersburg branch line. ${ }^{118}$ Formerly holding the same capacity for the B\&O, Latrobe's tasks beginning in 1852 included coordination of planning and operations between the $\mathrm{B} \& \mathrm{O}$ and the NVRR, or the line that $\mathrm{B} \& \mathrm{O}$ officials called the Parkersburg

\footnotetext{
${ }^{114}$ Ibid.

115 Twenty Sixth Annual Report BORR (1852), 33.

${ }^{116}$ Boorstin, The Americans, 296-8; Taylor, The Transportation Revolution, 97-102.

117 Twenty Sixth Annual Report BORR (1852), 33.

${ }^{118}$ Hungerford, The Story of the Baltimore \& Ohio Railroad, volume 1, 294.
} 
Branch. ${ }^{119}$ In selecting Grafton Junction, Latrobe knew that the site lay roughly equidistant from engineering features of both lines. Grafton served as a maintenance center for the entire division between Piedmont, Virginia, and Wheeling. The shops would also manufacture components for the Rowlesburg bridge crossing the Cheat River, the Monongahela River bridge near Fairmont, and the West Fork bridge near Clarksburg on the Northwestern Virginia line, as well as other structures. ${ }^{120}$ Before construction of the shops, however, B\&O work crews laid only two small rail sidings at Grafton, totaling 900 feet for slower trains to await overtaking by faster trains, or for short-term storage of rolling stock. As if to underscore attention to larger goals, half the sidings at Grafton were constructed of "T" rail and the rest of older light-duty "U" rail, which essentially was inverted iron channel stock spiked to wooden crossties. ${ }^{121}$ Northwestern Virginia Railroad officials would not be ready to build the Grafton shops until 1854.

Until completion of the Northwestern Virginia Railroad, no all-rail route to Cincinnati and the lower Ohio River valley existed. Traffic instead flowed through Wheeling on the main stem, then down the Ohio River, or followed the Northwestern Turnpike, which would reduce the journey by approximately 80 miles. "At Fetterman a line of Stage Coaches connected with our cars, once a day, and proceeded to St. Mary's, on the Ohio River, whence a line of Steamboats conveyed the mails and such few passengers as accompanied them," reported Swann to stock holders in $1853 .{ }^{122}$

${ }^{119}$ For an examination of the relationship of Benjamin Latrobe, Jr., Thomas Swann, the Northwestern Virginia Railroad to Parkersburg, and the Baltimore \& Ohio Railroad see Dilts, The Great Road, 283, 444; see also Address of Thomas Swann on the Parkersburg Rail Road (Baltimore, 28 June 1852), 13-4.

${ }^{120}$ Zembala, Grafton Machine Shop and Foundry Report, 9.

121 Twenty Seventh Annual Report BORR (1853), 4.

122 Twenty Seventh Annual Report BORR (1853), 19. 
For the suffering Northwestern Turnpike Company, superintendent J.D. Wilson had to anxiously acknowledge in 1852 that local traders from as far away as Clarksburg had abandoned the turnpike, already meeting the railroad at Fetterman instead. ${ }^{123}$ Completion of the $\mathrm{B} \& \mathrm{O}$ main stem caused a decline in quarterly income from toll gates between the Cheat and Tygart rivers, falling to $\$ 443$ in 1853 , compared to $\$ 949$ during the same time in $1851 .{ }^{124}$ In 1854 , Northwestern Turnpike superintendent A.G. Kidwell observed that "on the western end [Parkersburg] the receipts seem to be gradually diminishing as the Northwestern Virginia railroad approaches its completion." 125

Despite the best fiscal planning, land prices had risen sharply in the five years since Baltimore \& Ohio representatives first bought easements. In preparing to build engine facilities and storage yards at Grafton in July of 1854, the Northwestern Virginia Company paid significantly more for land than had the B\&O. Moses and Christina Luzadder supplied the necessary land for $\$ 315$, adjoining the right-of-way they had already sold to the Baltimore \& Ohio Company for a black silk dress. ${ }^{126}$ The previous August, John Prunty sold three acres along Simpson's Creek to the NVRR for $\$ 280 .{ }^{127}$ The presence of the B\&O Railroad may have only partly explained the increased land rates. NVRR officials, in an effort to elevate the value of their company, included the phrase "in consideration of the benefits and advantages arising from the construction of the North Western Virginia Rail Road through his lands" as standard language of their deed contracts, phrasing not included in $\mathrm{B} \& \mathrm{O}$ contracts. ${ }^{128}$ This may have heightened a sense of expectation and inclusion in

123 Ibid.

${ }^{124}$ Thirty Seventh Annual Report BPW (1852-1853), 140.

125 Thirty Ninth Annual Report BPW (1854-1855), 648.

126 TCCC, Deed Book 3, 300-1; Brinkman, "History of Taylor County," 15 May 1939.

127 TCCC, Deed Book 3, 543-4.

${ }^{128}$ Ibid, passim. 
landholders, but it also helped fan the flame of anticipated land values, reinforcing confidence that the railroad would surely bring prosperity.

In any event, most land owners increased their asking prices. For example, Daniel G. and Sarah Payne sold a right-of-way across eight acres for $\$ 750$ along Berkleys Run near Grafton. ${ }^{129}$ On average, land prices had risen to approximately $\$ 100$ per acre of easement for NVRR purchasing agents. ${ }^{130}$ In 1849 and 1850, B\&O agents had purchased rights-of-way for between $\$ 1$ and $\$ 5$ per easement across each acre. ${ }^{131}$ Prices increased not just for the railroad but for all land in and around Fetterman. In May of 1856, for example, James P. and Emily Sturgis of Preston County sold lot number 94 in Fetterman to Harrison and Redick Shields for $\$ 400 .{ }^{132}$ This contrasts with land values in 1850 and 1851 when the B\&O had first arrived at Fetterman and bought two 60 by 120 foot lots on opposite corners of Wilfred Street and Poplar Alley from Sarah Fetterman for $\$ 125$ and $\$ 75$, respectively. ${ }^{133}$

\section{Recompense}

In the process of building both the Baltimore \& Ohio and Northwestern Virginia railroads, numerous local land holders saw one of the disadvantages of railroad construction. To their dismay, farmers and landowners occasionally found that railroad construction crews had damaged their real estate. Even before the main stem had been completed in December 1852, some land holders filed
${ }^{129}$ Ibid, 529-30.
${ }^{130}$ Ibid, 526-35.
${ }^{131}$ Ibid, passim.
132 TCCC, Deed Book 4, 315.
133 TCCC, Deed Book 2, 304-5, 391-2. 
complaints with the Taylor County Court, the county's governing council. To address the issue, the court appointed a review commission comprised of land holders voluntarily taking seats to hear their neighbor's claims of property damage against B\&O Company activities. Some deeding agreements described pre-arranged alterations to property, but most did not. As seen in the commissioner's reports, damage suits almost invariably arose because railroad work crews had made alterations without prior consent from land holders..$^{134}$

As early as the summer of 1850 , with $\mathrm{B} \& \mathrm{O}$ construction crews barely beginning to clear the right-of-way in Taylor County, freeholders William P. Kemble, John W. Blue, Aaron Luzadder, Jacob Hull, Jr., and Noah Warder sat on the first of many investigating boards. Engineers for the $\mathrm{B} \& \mathrm{O}$ required more land for right-of-way construction than initially considered necessary, causing Isaac Trader, Thomas Goff, and Jacob Means to sue for damages for the B\&O's encroachment on their lands. Commissioners awarded $\$ 5$ to the complainants in April $1850 .{ }^{135}$ In June, Edwin W. Tower and John Hanway agreed to $\$ 5$ for damage to land and a fence before the damage had been done. ${ }^{136}$ Thomas W. Brooks accepted one of the largest settlements. Before construction in August 1850 , the $\mathrm{B} \& \mathrm{O}$ agreed to pay $\$ 124$ for inconvenience and probable damage. ${ }^{137}$

In July 1851, fifteen litigants in four different families—-the heirs of John Nuzum—claimed that $\mathrm{B} \& \mathrm{O}$ workers caused avoidable damage to a 13,300-foot-long stretch of properties along the Tygart River. James H. Potts, Abraham Williamson, and Richard Harr determined that B\&O hands had been reckless on land just outside Fetterman between the Tygart River and south side of the

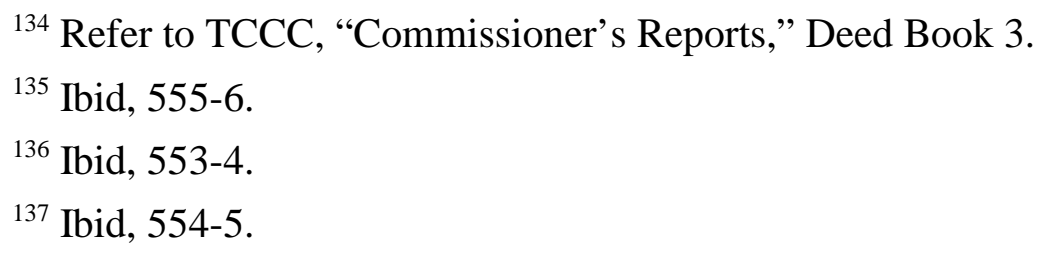


Northwestern Turnpike. The $\$ 75$ judgment for each complainant offset repairs and the cost of livestock fencing which $\mathrm{B} \& \mathrm{O}$ workers damaged. ${ }^{138}$

Monetary settlements for damage suits tended to be numerous but relatively small, generally between $\$ 5$ and $\$ 10$. By October of 1854 , commissioners had found the B\&O Company culpable for damages in each case it heard. B\&O planners and work crews endeavored to keep inadvertent damage to a minimum, but they foretold a trend of legal action against the $\mathrm{B} \& \mathrm{O}$ and, later, the Northwestern Virginia Railroad.

Damage judgements, like land prices for right-of-way construction, tended to be much higher for the Northwestern Virginia Railroad than for the B\&O, due perhaps to experience gained in dealing with the $\mathrm{B} \& \mathrm{O}$ and a heightened sophistication from that exposure. During construction of the Northwestern Virginia line in 1853, only months after completion of the B\&O main stem, damage suits began. As with the Baltimore \& Ohio, claims involved land alterations beyond any previously agreed to at the time of purchase. In April 1853, Thomas Holbert received $\$ 300$ for such damages. ${ }^{139}$ In February of the following year, Samuel Binegar received $\$ 550$ in compensation. ${ }^{140}$ Settlements ranged from $\$ 280$ for Theodore Davison to $\$ 620$ for Thomas J. Bartlett along the NVRR line in southern Taylor County. ${ }^{141}$ The maximum award paid from Baltimore \& Ohio coffers for such claims was $\$ 124 .^{142}$
${ }^{138}$ Ibid, 525-6.
${ }^{139}$ Ibid, 513-5.
${ }^{140}$ Ibid, 519-20.
${ }^{141}$ Ibid, 518-9.
${ }^{142}$ Ibid, 554-5. 


\section{Juncture}

Although Baltimore \& Ohio engineers intended to use Grafton as the junction point with the Northwestern Virginia Railroad, they needed to use the turnpike community of Fetterman as a temporary staging area. As Fetterman converted to a railroad town, its business community still owed its existence to the Northwestern Turnpike, and B\&O operations relied on a turnpike connection until May of 1857 when the NVRR opened. The presence of a major bridge contributed to the town's importance on Virginia's turnpike system, carrying fleets of stagecoaches from Parkersburg to the head of Baltimore \& Ohio construction as it progressed. Stages departed Parkersburg each Sunday, Wednesday, and Friday morning bound for connections to Baltimore. The 375-mile trip included a 165 -mile leg on the B\&O Railroad for a $\$ 15$ fare. $^{143}$

From the time the $\mathrm{B} \& \mathrm{O}$ main stem reached Fairmont in 1852, Fetterman became an intermediary community, both physically and figuratively. It lay at the convergence of two transportation innovations. As B\&O construction crews laid tracks through northwestern Virginia, Fetterman proved typical of dozens of small villages along America's growing rail network. Historian John Mack Faragher described the turnpike village of Auburn, Illinois, which shared the same time frame and many characteristics with Fetterman. Newly formed in 1840 and attaining prosperity due to its location at the intersection of a county road and major stagecoach line, the Alton \& Sangamon Railroad Company elected to bypass Auburn in favor of Wineman, Illinois, in 1851. The Alton \& Sangamon planned Wineman for their own purposes, drawing commerce away from Auburn. ${ }^{144}$ The town of Auburn soon fell into disuse. Until this fate befell Fetterman in the late

143 Advertisement, The Harrison Republican, 19 January 1849.

${ }^{144}$ Faragher, Sugar Creek, 173, 178-80. 
1850s and most of its citizens moved to Grafton and elsewhere, its residents enjoyed “ 'centrality' - the ability of a place to provide goods and services in excess of the needs of its own residents." ${ }^{145}$ By 1854, even before chartering, Grafton took on the centrality that Fetterman residents could not sustain by relying only on the turnpike.

Between 1849 and 1857, Fetterman's transition became clear. The Northwestern Turnpike formed the village, but the Baltimore \& Ohio Railroad transformed it, along with the region, into a railroad community with easy access to eastern manufacturers. In the case of Fetterman, dwindling traffic on the Northwestern Turnpike after the B\&O arrived in 1851 caused an economic downturn. When Baltimore \& Ohio facilities moved to Grafton, many existing business operators in Fetterman saw they were in an untenable position, and moved the mile or so to keep contact with the railroad. Topography, corporate planning, and urgency to complete the main stem gave Fetterman only a temporary advantage with market connections not possible using turnpike technology.

\section{Elbowroom}

In northwestern Virginia, at the eastern terminus of the Northwestern Virginia Railroad and its connection with the $\mathrm{B} \& \mathrm{O}$ main stem, Grafton sat in the middle of the most aggressive internal improvements plan in modern history to that time. Grafton residents had the fortune of living at a major railroad junction point on the main stem where regular train operations and a large sophisticated service and repair complex provided regular employment and easy opportunity for travel and shipping.

Grafton Junction proved nearly ideal for permanent facilities, and the engineering department

${ }^{145}$ Hudson, Plains Country Towns, 28. 
had plans for extensive building space east of the river junction along the north bank of Three Forks Creek. "A system of buildings for the joint accommodation" of both the B\&O and NVRR could commence with completion of the main stem, wrote Thomas Swann in $1853 .{ }^{146}$ B\&O directors, no longer consumed with reaching Wheeling, turned their attention to smaller matters. Latrobe did as well, situating water towers, rail yards, and service facilities for the Northwestern Virginia Railroad so that final route alignments and preparation for grading could commence with the fewest possible

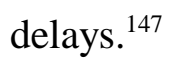

While the NVRR was under construction, immediate needs fixed Baltimore \& Ohio planners on temporary facilities at Fetterman. But Fetterman is located between relatively steep hills and a river, leaving little space for railroad use after the town grew with the turnpike, making obvious the need for another location with more room for construction. Average boxcars of the mid-nineteenth century measured approximately 35 feet long and six feet wide. Locomotives averaged just over twice that length. ${ }^{148}$ This required room for trains that could be 400 to 500 feet long as they awaited overtaking by faster trains, or unloading at local facilities. In addition, more facilities could be built for less money than what might be expected at the more confined and expensive space of Fetterman, while providing room for the operation of a second railroad. Larger facilities could be built at Grafton Junction than would be possible at Fetterman, thereby making room for the operation of two railroads.

After the Baltimore \& Ohio main stem opened in January 1853, Grafton Junction served as

${ }^{146}$ Twenty Seventh Annual Report BORR (1853), 4.

147 Ibid.

${ }^{148}$ These are average dimensions extrapolated from measurements taken by the author at the Baltimore \& Ohio Railroad Museum in Baltimore. 
a major interchange point for the B\&O, the NVRR, and the Northwestern Turnpike. ${ }^{149}$ It was a place where all rail-bound and local traffic on the turnpike would converge. In addition, connection with railroads then under construction in Ohio, Indiana, and Illinois provided the broad reach $\mathrm{B} \& \mathrm{O}$ planners envisioned. ${ }^{150}$ Commercial traffic both from the lower Ohio River to St. Louis, Missouri, and the north central plains would pass through Grafton by the beginning of the Civil War.

In October 1853, construction crews began building maintenance facilities and storage yards for rolling stock and passenger cars in Grafton Junction. ${ }^{151}$ Locating at Grafton would move B\&O operations only about one mile east of the Northwestern Turnpike depot at Fetterman. The B\&O Company bought a plot roughly 500 by 1,100 feet from Moses and Christina Luzadder in July, 1854, for $\$ 175 .^{152}$ On the same day, NVRR agents bought a slightly larger plot from the Luzadders for their planned machine shops and engine roundhouse for $\$ 315 .^{153}$ The Luzadders' land encompassed a flat, low-lying flood plain which proved to be a very good location for railroad yards as several future expansions eastward along Three Forks Creek would demonstrate. ${ }^{154}$

Baltimore stock holders and B\&O loans supported the Northwestern Virginia Railroad, and the investment made in the design and construction of the Grafton shops for the NVRR demonstrated from the outset the intent of $\mathrm{B} \& \mathrm{O}$ administrators to take control of the Parkersburg Branch. The shop's roof support system, for example, was little more than a series of small bridges that $\mathrm{B} \& \mathrm{O}$ 396.

${ }^{149}$ Stover, History of the Baltimore and Ohio Railroad, 72; Dilts, The Great Road, 328,

${ }^{150}$ Frey, Railroads in the Nineteenth Century, xviii, xxii.

${ }^{151}$ Engineering Report of Benjamin H. Latrobe, Jr., Twenty Seventh Annual Report BORR (1853), 4.

152 TCCC, Deed Book 3, 298-9.

${ }^{153}$ Ibid, 300-1.

${ }^{154}$ Zembala, Grafton Machine Shop and Foundry Report, 12. 
engineer Albert Fink had designed only a few years earlier. The tri-composite construction roof trusses employed timber cross beams supported by wrought and cast iron components which provided a 50 by 250 foot interior space, an extraordinary amount of work area placed under shelter for foundries, machining equipment, and forges. ${ }^{155}$

The maintenance and engine shops at the $\mathrm{B} \& \mathrm{O}$ and NVRR junction and the operation of freight and passenger rail service not only required hundreds of people and awe-inspiring machinery. A new style of personnel management was also needed to maintain smooth operations based on corporate needs, service to customers on a mass scale, and timing that would introduce strict scheduling and clocks to a populace unaccustomed with either.

Early in 1855 , a fire destroyed the B\&O shops and engine houses at Fetterman. ${ }^{156}$ At the time, Fetterman's temporary facilities already showed the wear of neglected maintenance and rough conditions. Before the fire, the depot had required $\$ 630$ of expenditures, and Fetterman's water tower needed $\$ 188$ for repair materials and labor. ${ }^{157}$ In the fire, the B\&O lost a building valued at $\$ 8,037$ containing $\$ 1,916.35$ worth of tools, lathes, machinery, and a stationary steam engine. Relocating operations and building new structures became imperative. ${ }^{158}$ Operations moved to the less expensive bottom land at the confluence of the Tygart River and Three Forks Creek. To help compensate the NVRR for the inconvenience of such a major, unscheduled move, the $\mathrm{B} \& \mathrm{O}$

${ }^{155}$ Ibid, $10-1$.

${ }^{156}$ Thirty First Annual Report BORR (1857), 44-5; Baltimore \& Ohio Rail Road Company Minute Book "H" (1857), 217; Brinkman, "Early History of Grafton," 6 September 1929.

157 Twenty Ninth Annual Report BORR (1855) 71, 73.

${ }^{158}$ Twenty Eighth Annual Report BORR (1854), 50, 91; Thirtieth Annual Report BORR (1856), 106. 
Transportation Department agreed to build two houses for NVRR officers at Grafton. Construction began in the summer of $1858 .^{159}$

With the move, Grafton Junction began to grow. One indicator of growth in a railroad town is the measure of commercial sidings and marshaling yards constructed there. At Grafton, work crews laid 900 feet of both heavy- and light-duty rails in 1855 for siding tracks, enough room for the longest freight and work trains. ${ }^{160}$ The following year, the Northwestern Virginia Railroad added 386 feet of rails connecting the main stem with the NVRR Tygart River bridge, and the B\&O increased its yard to 1,250 feet. $^{161}$

Clearly, the machine shops and scope of operations at Grafton far exceeded the resources of the Northwestern Virginia Railroad. ${ }^{162}$ Indeed, B\&O trustees had signed a five-year lease agreement for the NVRR in 1856, circumventing the NVRR's charter by operating the line before a year had expired after completion. The Northwestern Virginia Railroad officially opened on 1 July 1857, and according to the railroad's charter, would not be allowed to carry commerce until July 1858 after approval by the Virginia legislature. ${ }^{163}$ In 1857 , when the NVRR became operational, its new president, Thomas Swann, admitted that commerce on the line "cannot in any large extent be regarded as a positive addition to the business of the Baltimore and Ohio Railroad proper," but he

${ }^{159}$ Baltimore \& Ohio Rail Road Company Minute Book “H” (1857), 259-60.

${ }^{160}$ Twenty Ninth Annual Report BORR (1855), 64.

161 Thirtieth Annual Report BORR (1856), 84.

162 Thirty First Annual Report BORR (1857), 44-6.

${ }^{163}$ Dilts, The Great Road, 444; Stover, History of the Baltimore and Ohio Railroad, 115; Thirty First Annual Report BORR, 6, 10; Representatives of the city of Wheeling filed a lawsuit against the $\mathrm{B} \& \mathrm{O}$ and the NVRR after the lease agreement had been enacted to keep the Parkersburg Branch from opening, but was dropped before the Virginia courts had reached a decision. Refer to Hungerford, The Story of the Baltimore \& Ohio Railroad, 293-4. 
was most confident that the commercial situation would improve. ${ }^{164}$

Railroads fostered a spirit of competition among the communities along the rails similar to that seen among eastern port cities. In 1856, the year Virginia incorporated Grafton, an editorial in the Fairmont True Virginian chided Fairmont residents for their lack of attention to keeping home, town, and property appearances clean and orderly. The city appeared dirty and unkempt. The older, established town of Fairmont was losing rail traffic and business to upstart Grafton, even though Fairmont also lay on the main stem. The editorial noted that Fairmont's inhabitants "prefer spending their time in sloth," while in Grafton, "the property holders build neat houses and inclose their lots and yards with neat fences, all painted or whitewashed." In urging residents to take greater care before commercial interests and the $\mathrm{B} \& \mathrm{O}$ slighted the town, the editorial held out the example of Pruntytown after the turnpike became obsolete as a potential scenario of decline. As a warning, the editor reviewed land prices, noting that within yards of the courthouse in Pruntytown, plots sold for as little as $\$ 30$ per acre, whereas in the new town of Grafton, land already sold for about $\$ 100$ an acre or more. Even the town's only surviving newspaper, the Pruntytown Gazette, had "died a painful death." 165 To a growing nation facing vast territories and a drive to populate new lands, railroads represented a made-to-order tool—if an expensive one to employ—-to turn grand dreams into reality. They also broadened the scope of city competition beyond the Atlantic seaboard. ${ }^{166}$

In 1857, the Baltimore \& Ohio Transportation Department assumed control of the Grafton

164 Thirty First Annual Report BORR (1857), 44.

${ }^{165}$ Editorial, "Pruntytown, Grafton, Fetterman, Fairmont," Fairmont True Virginian, 14 June 1856.

166 Taylor, The Transportation Revolution, 74-103. 
machine shops. Constructed at a cost of $\$ 145,026$, including some tracks, it was fully equipped. ${ }^{167}$ Outfitted with smithing shops, metal shear and punch machines, wheel and axle forges, and a new steam-powered trip hammer, shop workers could repair even the most complicated damage to bridges, locomotives, and rolling stock alike. ${ }^{168}$ In addition to commerce represented in the large depots and rail yards for the community, a spin-off effect resulted from the advanced technology of the machine shops. In the 1850s, only specially trained artisans, machinists, and engineers would have been familiar with the steam engines and machining tools of the early industrial era. The tools and machines equipping Grafton's facilities exposed local men and boys to new technology that reasonably can be expected to have increased their general mechanical understanding and ability, influencing their own lives as much as the community in which they lived. ${ }^{169}$ By 1857 , with the NVRR operational, Grafton's B\&O yard had grown to 4,660 feet of heavy-duty rails. In addition, the Northwestern Virginia Railroad, by then officially called the Parkersburg Branch in B\&O records, had constructed 5,239 feet of adjacent yard tracks at Grafton. ${ }^{170}$

In 1857, Grafton's newly finished passenger depot handled 3,287 passengers, accounting for 404,639 miles traveled. ${ }^{171}$ By contrast, Fetterman handled 2,165 passengers, approximately twothirds of Grafton's trade and a decrease of about 2,000 passengers from the previous year; a harbinger of a steady decline. ${ }^{172}$ Over 8,000 passengers used Grafton's station in 1859, accounting

${ }^{167}$ Thirty First Annual Report BORR (1857), 6.

${ }^{168}$ Thirty Fourth Annual Report BORR (1860), 157-9.

${ }^{169}$ Zembala, Grafton Machine Shop and Foundry Report, 2, $15-7$.

${ }^{170}$ Thirty First Annual Report BORR (1857), 119, 123.

${ }^{171}$ Ibid, 56.

${ }^{172}$ Ibid; Thirtieth Annual Report BORR (1856), 42. 
for just short of 1,000,000 travel miles. ${ }^{173}$

Small single-industry towns like Grafton demonstrated a new form of community different from Richmond or Baltimore. Railroads made Grafton a boom town and commercial center. Its population grew quickly, fluctuating in number and composition as a transportation center. The railroad and natural resources, such as two water courses and gently rolling land in a mountainous region for construction, drew railroad workers, local farmers, and settlers looking for a fresh start and opportunities for work. Grafton's modest beginnings were similar to those of most American communities, but the presence of two railroads raised a stark contrast from agriculture and accelerated a previously slow process of community growth.

In the words of historian Daniel Boorstin, Grafton is a surviving "Upstart" community. ${ }^{174}$ Its history can be traced to the designs of railroad boosters, including a handful of Baltimore and Parkersburg investors. ${ }^{175}$ In the case of Grafton, it was the railroad that introduced industrialization and "added most to the material wealth of Taylor County," providing the catalyst for businesses that would engage in national markets. ${ }^{176}$ Railroad technology accelerated the economic paradigm shift from local subsistence to far-reaching commercial affiliations begun during the turnpike era.

173 Thirty Third Annual Report BORR (1859), 76.

${ }^{174}$ Boorstin, The Americans, 113-4.

${ }^{175}$ For a more complete examination of American boosterism, see Boorstin, The Americans, 115-68; Charles Sellers, The Market Revolution: Jacksonian America, 1815-1846 (New York: Oxford University Press, 1991), 44-5, 380.

${ }^{176}$ John W. Mason, “Our Great Centennial Celebration,” Grafton Sentinel, 15 July 1876. 


\section{Chapter 3}

\section{Railroad Town}

The essence of community may be in doing something, not in being something. ${ }^{1}$

When the Northwestern Virginia Railroad joined with the Baltimore \& Ohio main stem at the confluence of the Tygart River and Three Forks Creek, Benjamin H. Latrobe, Jr., called it "a point of prominent importance upon the road." ${ }^{2} \mathrm{~B} \& \mathrm{O}$ timetables called the new town Parkersburg Junction until 1852 or $1853 .^{3}$ Called Grafton Junction for a very short time after 1853 , the Commonwealth of Virginia dropped "Junction" on 15 March 1856 and incorporated the town of Grafton. ${ }^{4}$ Several anecdotes exist as to how Grafton received its name. One account tells of a civil engineer employed by the B\&O Railroad named Grafton, but a search of records at the Baltimore \& Ohio Railroad museum archives in Baltimore does not reveal him. Another credits Irish laborers with bestowing the name to commemorate home, but period maps of Ireland reveal no support for that theory. Perhaps the most plausible anecdote credits $\mathrm{B} \& \mathrm{O}$ administrators with identifying the confluence of the Tygart River and Three Forks Creek as the point where the Parkersburg Branch grafted on to the Baltimore \& Ohio main stem to Wheeling. B\&O founders saw their railroad as analogous to a great living tree rooted in Baltimore with its branches stretching out across the western lands. At the cross roads of efforts to connect the upper and lower Ohio valley with eastern

${ }^{1}$ Robert V. Hine, Community on the American Frontier: Separate but Not Alone (Norman, Oklahoma: University of Oklahoma Press, 1980), 31.

2 Twenty-Seventh Annual Report BORR (1853), 4.

${ }^{3}$ Baltimore \& Ohio Rail Road Company Minute Book “G," 1 August 1853 Engineer's Report, 281.

${ }^{4}$ Brinkman, "History of Taylor County," 20 May 1939; Acts of the Virginia General Assembly (1855-6), 188-9. 
markets, $\mathrm{B} \& \mathrm{O}$ officials early recognized Grafton as an important junction point in company plans. Thomas Swann harkened upon the company's analogous tree by calling Grafton "the common trunk at Three Forks." ${ }^{5}$

By the mid-1850s, Grafton residents could count two hotels, four taverns, two established boarding houses, and a score of mercantile concerns built mainly for the benefit of railroad workers, wayfarers, and freight exchange. In addition, any family with room to spare rented to boarders. Its busiest thoroughfares, Elizabeth (Main) and Railroad streets, running east and west parallel with the railroad main line, were crowded daily with horse teams and laden wagons, threading their way among travelers and townsfolk. Irish railroad workers established makeshift Catholic churches in the homes of Thomas Shanley, John Doonan, and James Whelan soon after ending employment with the B\&O. A Methodist congregation used Peter Wolf's Elizabeth Street home. All shared Grafton's south side with the Baltimore \& Ohio Railroad. ${ }^{6}$ Moses Luzadder, recognizing that a town would soon grow at the junction of the $\mathrm{B} \& \mathrm{O}$ and Northwestern Virginia railroads, capitalized on the opportunity by selling land. At public auctions in the mid-1850s, just as Grafton received its town charter, Luzadder sold one-acre town lots for $\$ 35$ to $\$ 40$ bids, land valued at from $\$ 2$ to $\$ 7$ in $1848 .^{7}$

As the B\&O Railroad became a fact of life, the composition of Grafton's population transformed. The earliest residents in the lower Tygart valley knew land characterized by dense laurel thickets, heavy forests, and simple farming. In less than a decade, between 1847, when the

${ }^{5}$ Address of Thomas Swann on the Parkersburg Railroad, 28 January 1852, 8.

${ }^{6}$ Brinkman, "Early History of Grafton," 4, 5 and 6 September 1929; Acts of the Virginia General Assembly (1855-1856), 188.

${ }^{7}$ Brinkman, "History of Taylor County," 15 May 1939; TCCC, Land Book 1848-1855. 
B\&O's second Virginia charter set Wheeling as its only acceptable terminus, and 1856, when Grafton received its charter, the region's economy changed from agriculture to industry.

In addition, the railroad town of Grafton would ultimately dominate the turnpike village of Fetterman because of the B\&O Railroad. Although the two towns' populations were never really in competition with each other, as were Baltimore, Philadelphia, and New York, the community of Fetterman continued to rely on an increasingly obsolete technology. In fact, the transition from turnpikes to railroads in Taylor County occurred so rapidly that most Fetterman residents may not have realized they were in a race until it was too late. In a practical sense, the Baltimore \& Ohio and Northwestern Virginia railroads made Grafton and Fetterman one community by the Civil War. Railroad technology reduced the effect of distance so that one mile of separation between Grafton and Fetterman would not preclude consolidating two towns.

As Grafton took root and expanded, it followed a pattern that would be familiar to most Americans living near the railroad lines of the Great Northern, Union Pacific, Illinois Central, and a dozen other western lines during the post-Civil War railroad boom. Grafton's earliest history shared significant similarities with developing railroad towns that historian John Hudson described on the Dakota plains in the 1880s. This suggests a trend that applies to railroad communities evolving in a nineteenth century free market economy, a generalization useful within limited parameters. Hudson described a system that railroad companies devised for positioning and building towns following a formula. On the western plains of the 1870s and 1880s, railroad companies carefully planned towns not only for track alignment, work shops, water tanks, and so forth, but for streets, schools, public buildings, and commercial areas, as well. ${ }^{8}$ Grafton too was a planned

\footnotetext{
${ }^{8}$ Hudson, Plains Country Towns, 7-15.
} 
community, but not to the extent Hudson had described. It grew where it did because of topography favorable to the B\&O Railroad. Like Boston and Philadelphia, two of the most influential models for American communities in the early 1800s, Grafton residents laid out the town as a basic grid of east to west oriented rectangular blocks superimposed upon the valley and hillsides. ${ }^{9}$

Created before America's expanding rail system spawned so many new towns that they essentially had to be mass produced, Grafton represents the primary stages of what would become a characteristic railroad town. Although the B\&O did not own Grafton, the railroad's basic operating needs took precedence over its development. Grafton as a place proved to be just one element in the plans and improvisations needed to make the whole B\&O system work coherently. After the railroad had claimed what it needed, Grafton residents built on the usable land remaining.

\section{Grafton}

After completion of the main stem, Grafton began attracting former construction workers, railroad hands, and entrepreneurs to build homes, farms, and businesses. Among the workers contracted by the $\mathrm{B} \& \mathrm{O}$ to clear trees from the right-of-way at $\$ 1$ per day was Henry Compton. With his work completed by the fall of 1852 and the first trains running, Compton called for his family to settle in the new community. ${ }^{10}$ The handful of families then residing at the B\&O junction with the Northwestern Virginia Railroad were only the seeds of a larger community, and Compton saw his opportunity to make a new home. Settling at the corner of Elizabeth (Main) and St. John streets

${ }^{9}$ For analysis of nineteenth century city planning see John W. Reps, Cities of the American West: A History of Frontier Urban Planning (Princeton University Press, 1979).

${ }^{10}$ List of Officers and Employees in the Service of the Baltimore \& Ohio R. Road, 46; Brinkman, "Early History of Grafton," 3 September 1929. 
on Grafton's east side, the Comptons had six children and the beginnings of a prosperous life. ${ }^{11}$

In addition to Compton, numerous railroad workers set down roots at Grafton after completing the main stem to Wheeling, accounting for the town's population of 150 by $1853 .^{12}$ Many were like Simeon Jasper Snider, age eighteen while employed by the Baltimore \& Ohio during main stem construction. After completion of the main stem, he married eighteen-year-old Martha Ellen Green at Fetterman on New Year's Day in 1854 and took up residence in Grafton. ${ }^{13}$

Work on the railroad also drew one of Snider's friends, Thomas McGraw, an emigré from Galway, Ireland, who headed a railroad construction crew. As foreman of the first main stem track crew through the Tygart valley in January 1852, McGraw was immediately struck by the beauty and serenity of the area, perhaps seeing semblances of his homeland in the lush green valleys of northern Virginia. In 1853, he opened a general store on Railroad Street near the Grafton House tavern and married Mary B. Ludey; they had six children. ${ }^{14}$ McGraw sold dry goods, groceries, and general merchandise, including "choice Liquors in great variety.",

Straight away, McGraw began investing in land. Moses and Christina Luzadder sold him lot number four near the mouth of Three Forks Creek, measuring roughly 86 by 74 feet with an irregular boundary, on 30 November $1853 .^{16}$ Five months later, McGraw purchased a one-quarter acre lot in Grafton from Harrison and Julia Jaco. Both parcels cost $\$ 140$ and eventually became rental

${ }^{11}$ TCCC, Will Book 2, 401-3.

12 Brinkman, "History of Taylor County," 19 May 1939.

${ }^{13}$ Brinkman, "Early History of Grafton," 5 September 1929; Zinn, Taylor County in Profile, 1.

${ }^{14}$ A History of Taylor County, West Virginia, 306.

${ }^{15}$ Advertisement, Grafton Guardian, 7 September 1860.

${ }^{16}$ TCCC, Deed Book 3, 239-40. 
properties. ${ }^{17}$ By 1859 , however, prices had already begun to climb because of the railroad. In that year, McGraw purchased lot number 43 for $\$ 200$ from Henry A. and Ellen O'Leary in South Grafton, an unincorporated village across the river along the Northwestern Virginia Railroad tracks. ${ }^{18}$ James K. Smith, justice of the peace and Fetterman's railroad agent, notarized the deed. ${ }^{19}$

Adjoining his general store, McGraw built a large wood-framed home in the late 1850s facing south onto Railroad Street for his wife and growing family. The upper floors of the store and the empty rooms in the house soon lodged boarders, becoming known as the McGraw Hotel and Rooming House. When their boarding house business began to overwhelm his family, McGraw had Nathan Goodwin build a new three-story brick home for his family, relegating his former abode to housing tenants. Located a short distance away at 120 Latrobe Street at the present-day site of the Taylor County jail, it reflected McGraw's increasing prosperity with the more expensive brick construction. It also faced the railroad yards, acknowledging McGraw's roots in railroading. ${ }^{20}$

After establishing one of the first mercantile businesses in Grafton, McGraw invited his close friend, Patrick O'Conner, to visit. O'Conner, also a business operator along the $\mathrm{B} \& \mathrm{O}$ main stem in Moundsville, Virginia, examined the desolate setting McGraw had chosen to make his home, and exclaimed that "no town can ever be built here. The foxes will be looking out of the windows of your house in less than a year."21 However, within that year, O'Conner moved from his Moundsville general store to Grafton, following a trend that would inflate the town's population to approximately

${ }^{17}$ Ibid, 267-8; A History of Taylor County, West Virginia, 306.

18 TCCC, Deed Book 6, 551.

${ }^{19}$ Ibid.

${ }^{20}$ A History of Taylor County, West Virginia, 306.

${ }^{21}$ John W. Mason, The Grafton Sentinel, "Our Great Centennial Celebration," 15 July 1876. 
3,000 , and Taylor County's population to just over 9,000 by the $1870 \mathrm{~s}^{22}$

John A. Doonan, another Irish-born railroad worker and close friend of McGraw, also chose to make Grafton his home. Born in 1824, Doonan moved to Hampshire County, Virginia, in 1842. By 1854, Doonan pursued other occupations by building a modest home and mercantile business in Grafton. Within a short time, he expanded beyond the general store to open the three-story Palace Hotel on St. John Street. Doonan also joined the ranks of land investors by purchasing over twenty houses and numerous plots in and around Grafton, as well as working farms both in Taylor and Preston counties. ${ }^{23}$

Grafton, like any thriving community, needed doctors. In 1856, Dr. Thomas Kennedy answered their need. A Lancaster County, Pennsylvania, native, Kennedy graduated in 1848 from the College of Physicians and Surgeons in Philadelphia. After living for a time at Oliphant Furnace along the Cheat River near Morgantown, where he worked occasionally as a teacher to earn extra money, Kennedy moved to Evansville in Preston County. The Northwestern Turnpike passed through Evansville. Perhaps new technology and the potential for adventure, in addition to the need for physicians in the isolated communities of northern Virginia, attracted Kennedy. In 1856, he moved to Grafton with his wife, Clara.

Railroads alleviated isolation in many northern Virginia towns and added to commercial prospects. Grafton's citizens, however, struggled to make tangible the vision and ambitions of railroad boosters that lived far from Taylor County. Again referring to Sangamon County in John Mack Faragher's Sugar Creek, this same process could be seen. After isolation and working for

\footnotetext{
${ }^{22}$ Ninth Census of the United States, Statistics of Population (Washington: Government Printing Office, 1872), 71, 286.

${ }^{23}$ John Doonan obituary, The Grafton Sentinel, 12 December 1902.
} 
competency on the Illinois plains, a railroad line between Chicago and Alton, Illinois, brought great excitement and hopeful anticipation. During the nineteenth century, competency generally meant a family's pursuit of sufficient food, good shelter, and relative comfort within the structure of a market oriented system. ${ }^{24}$ Historian Daniel Vickers defined "competency" as "a degree of well-being that was both desirable and morally legitimate, a degree of comfortable independence." 25 "Sangamo men appeared to be more and more convinced that transportation development offered the best way to break into the market economy."${ }^{26}$ Residents of Alton, like the settlers of Grafton, saw prospects in a transportation mode which could cheaply carry farm goods to competitive markets and bring consumer goods to them at a reasonable price, a process which could not help but make communities grow and simplify competency.

Most new settlers in the Tygart River valley saw transportation improvement as one of the few things which would make their own circumstances as a developing commercial quarter more certain and more comfortable. Reliable connections with markets would supply necessities and luxuries, as well as provide outlets for farm produce, coal, and pig iron. In the time between Grafton's establishment as a railroad hub in 1852 and the beginning of the Civil War, more than a depot to serve the railroad had been formed. A community of workers, merchants, and families, equipped with their respective aspirations, had taken shape. In addition, as a railroad town, Grafton represented a singular part of a much larger system.

\footnotetext{
${ }^{24}$ For further reading on "competency," see Hahn and Prude, The Countryside in the Age of Capitalist Transformation, 75, 78, 95.

${ }^{25}$ Daniel Vickers, "Competency and Competition: Economic Culture in Early America," The William and Mary Quarterly, Third series, 47 (January 1990), 3.

${ }^{26}$ Faragher, Sugar Creek, 178.
} 
The Tie That Binds

Even with completion of the B\&O main stem and Northwestern Virginia line, labor shortages hindered commercial growth at Grafton and early railroad operations. The economic well-being of the community was directly connected to $\mathrm{B} \& \mathrm{O}$ operations from the first work trains arriving in the Tygart River valley. Local commerce grew proportionate to trade, farm production, and workers at hand, but a small work force due to the area's low population impeded commercial expansion.

Recognizing that most of the small towns along the main stem and Washington Branch suffered from labor shortages, Baltimore \& Ohio administrators had started to modernize their operations as early as 1849 . To better coordinate workers and hold on to reliable mechanics, the board of directors approved conversion of all major shops from strictly maintenance and repair facilities to full-fledged construction plants. Because of these changes, virtually any part for locomotives or rolling stock could be fabricated at the Grafton shops upon completion in 1857. Cars and engines could be made from scratch if necessary. Maximum efficiency of the shops and work crews would be realized if trained, experienced laborers and artisans were less susceptible to seasonal fluctuations and were employed year round, using already capitalized structures to reduce costs for rolling stock and locomotives. ${ }^{27}$ At times of peak demand for railroad transport, such as autumn harvest, when market prices for livestock might be high, or holiday excursions, many more workers would be needed to handle increased rail traffic than would otherwise be required for normal operations. During severe winter weather, train service and regular track maintenance had to be curtailed, but indoor work could readily continue. At the Grafton shops, over 150 workers would be needed to operate the trip hammer, blacksmith forges, wheel and axle forges, machine

\footnotetext{
${ }^{27}$ Twenty Third Annual Report BORR (1849), 8.
} 
shops, and locomotive works. ${ }^{28}$ Combined with the number of workers needed to operate trains, including an engineer, fireman, conductor, and at least one brakeman for each train, over 250 men worked out of Grafton at peak times. ${ }^{29}$

In Grafton and other places along the line in rural Virginia, laborers needed less to make a living than those in Baltimore or any large city. If the $\mathrm{B} \& \mathrm{O}$ could not retain workers year-round, they did not abandon hope of working for the railroad. A railroad worker's income could be subsidized with individual farming, by hiring out to area farmers, or with part-time work in other trades. Machinery department jobs were most desirable on a system-wide basis, though, because workers there averaged two months more employment per year than those in the transportation department. $^{30}$

Seniority played a very important role in the amount of work any given employee could hope to receive. "Since assignments were in the hands of local foremen, it proved both advantageous and wise to remain in the good favor of one's superior," observed historian Walter Licht. ${ }^{31}$ B\&O officials advised their employees that only regular pay could be expected, almost regardless of the amount of time a given job may take. "John Garrett of the Baltimore \& Ohio wrote that twelve hours constituted a standard day's work on that line, although he admitted that B. \& O. freight trainmen usually worked anywhere from sixteen to twenty hours." ${ }^{, 32}$ In other words, no overtime pay could be expected. On limited occasions, under extraordinary circumstances, additional pay could be

${ }^{28}$ Brinkman, "History of Taylor County," 22 May 1939.

${ }^{29}$ Zembala, Grafton Machine Shop and Foundry Report, 10-3.

${ }^{30}$ List of Officers and Employees in the Service of the Baltimore \& Ohio R. Road, 97.

${ }^{31}$ Walter Licht, Working for the Railroad: The Organization of Work in the Nineteenth Century (Princeton, New Jersey: Princeton University Press, 1983), 171.

${ }^{32}$ Ibid, 176. 
given, but only at the discretion of local supervisors and company officers. Prior to 1854 , for example, B\&O administrators granted more liberal overtime pay to expedite completion of the line. But company attitudes changed in $1854 .{ }^{33}$ Indeed, many of the railroad workers who helped lay the main stem may have expected continued employment with the $\mathrm{B} \& \mathrm{O}$ after its completion, and some did. But most found that part-time and seasonal work with the railroad would be the rule.

In addition to working directly for the railroad, the $\mathrm{B} \& \mathrm{O}$ stimulated a wide range of other commercial ventures and services for people of the Tygart valley. The federal government awarded mail contracts based on delivery speed and dependability, for example. Proving its reliability early on, the Baltimore \& Ohio Railroad regularly carried the post between Washington, Baltimore, and Cumberland by 1842, and Grafton residents benefited from that service as the main stem opened. ${ }^{34}$ In addition, the $\mathrm{B} \& \mathrm{O}$ began using magnetic telegraphs to transmit messages after tests on the Washington Branch in $1844 .^{35}$ The telegraph proved essential to railroad operations by the mid1850s, carrying train movement information and orders, as well as business and personal communications. Almost immediately, a community's telegraph station became as important as its farms, blacksmiths, and mercantile establishments. ${ }^{36}$ This made Grafton's circumstances atypical for the 1850s because so few towns had telegraph stations at the time. But the town's situation was similar to far western railroad towns during the late 1860s through 1880s whose news, shipping information, and train movements flowed on a daily basis by telegraph. ${ }^{37}$

${ }^{33}$ Ibid, 178.

${ }^{34}$ Sixteenth Annual Report BORR (1842), 21.

${ }^{35}$ Stover, History of the Baltimore \& Ohio Railroad, 59-60.

${ }^{36}$ Allen Pred, City-Systems in Advanced Economies: Past Growth, Present Processes and Future Development Options (New York: John Wiley and Sons, 1977), 38-41.

${ }^{37}$ Ibid, 38-9. 
Grafton's depot received newspapers almost daily from publishers all along the B\&O system. Due to a provision in the Postal Act of 1792, allowing free post for newspapers being sent between editors to encourage an informed public and a free exchange of ideas, Grafton's journalists received news from every city in the northeast and Atlantic coast. ${ }^{38}$ Newspaper publishers also relied on telegraphic communications, creating another information link for the community. ${ }^{39}$ This activity provided Grafton's citizens a unique opportunity to garner the most current dispatches simply by visiting the Grafton Hotel and passenger depot. With the railroad and telegraph, Grafton's business community had a communications advantage surpassing that of Fetterman or Pruntytown along a turnpike in declining use, helping to promote a sense that Grafton should become the county seat.

Knowing that the main stem and Parkersburg Branch would eventually carry thousands of passengers, Baltimore \& Ohio administrators also wanted to build a first class hotel and restaurant facility at Grafton, celebrating the grandeur and importance of the new rail route. In the early years of American railroading, night time operations were rare events due to inadequate light generation equipment on locomotives and the subsequent risks involved. ${ }^{40}$ This required passenger trains to make regular overnight stops, so railroads built hotels. Baltimore \& Ohio administrators understood the need for a first class facility at one of the busiest and most important stations on the main stem, and designated a comparatively large structure featuring comfort, convenience, and as much opulence as practical. The board of directors authorized $\$ 10,000$ in July of 1856 to build the

\footnotetext{
${ }^{38}$ Annals of the Congress of the United States, January 1792, 63-4.

39 Taylor, The Transportation Revolution, 152.

${ }^{40}$ Twenty Sixth Annual Report BORR (1852), 51; Thirty Third Annual Report BORR
} (1859), 12. 
Grafton Hotel. ${ }^{41}$ The following September, they approved a $\$ 3,000$ cost overrun to complete the building as designed. ${ }^{42}$

Set on a wedge-shaped lot formed by the junction of the Baltimore \& Ohio and Northwestern Virginia tracks, the B\&O built the Grafton Hotel to be the quintessence of elegance and function following the Italianate style of architecture. Architectural historian Spiro Kostof observed that, commonly, hotels were the first buildings designed by trained architects in American cities. Contrary to the wood frame buildings done with vernacular methods, these structures were built in a specific style tending to impart civic pride in the community's citizens. ${ }^{43}$

Compared favorably with hotels in large cities, the edifice early instilled confidence and esteem in the citizens of Grafton, most of whom worked for the B\&O or had family members who did. It stood for over eighty years as a point of local pride. ${ }^{44}$ One of the busiest in the B\&O system, the hotel also stood as manifestation of the highest good possible with railroads, a tangible representation of earlier promises that abundance could be expected. ${ }^{45}$ If this new community would be a success, the source of progress would be the B\&O Railroad.

Popular in the mid-1800s and employed for construction of both private and public edifices, the decade preceding the Civil War saw the Italianate style's peak of favor. Buildings featured simple hipped roofs with decorative brackets supporting the eaves, unadorned exterior walls, modest

${ }^{41}$ Baltimore \& Ohio Rail Road Company Minute Book “H” (1856), 108.

42 Ibid, 130.

${ }^{43}$ Spiro Kostof, A History of Architecture: Settings and Rituals (New York: Oxford University Press, 1985), 631.

${ }^{44}$ Hungerford, The Story of the Baltimore \& Ohio Railroad, volume 1, 305; Brinkman, "History of Taylor County," 27 May 1939.

${ }^{45}$ Kostof, A History of Architecture, 617-22. 
doors and windows, occasionally with small square cupolas or towers positioned at the roof peak or off-set within the structure. ${ }^{46}$ Italianate provided the sense of informal ease seen in a Renaissance villa warmly waiting for tired passengers ${ }^{47}$ Roominess was the watch word for the design with large parlors, a generous lobby, and a dining room "capable of accommodating an immensity of humanity." ${ }^{48}$ The Grafton Hotel had dining facilities in close proximity to the passenger depot. The building used coal gas for lighting, and passengers refreshed in an ante-chamber next to the main entrance that housed a double row of washstands. ${ }^{49}$ Henry Luethke and a Baltimore \& Ohio work crew laid a platform of stones for the depot drawn from a quarry on Grafton's east end. ${ }^{50}$ This facility served hundreds of guests each year from common laborers to heads of state.

The hotel open in April 1857 under the supervision of Mrs. Minerva Bean. ${ }^{51}$ Bean, who furnished and appointed the hotel upon approval of the president and board of trustees, paid an $\$ 800$ lease agreement for the first year of operation, and $\$ 1,000$ annually thereafter. ${ }^{52}$ Originally intended to be named the Grafton Station, Baltimore \& Ohio president John W. Garrett, who took office in 1858 and had a close personal interest in the combination hotel, passenger station, and freight depot, substituted the word "hotel" for "station." ${ }^{53}$ The hotel's manager was Horace Resley of Baltimore. ${ }^{54}$

${ }^{46}$ John C. Poppeliers, et al., What Style Is It (New York: John Wiley and Sons, 1983), 469; Virginia and Lee McAlester, A Field Guide to American Houses (New York: Alfred A. Knopf, 1984), 211-4.

${ }^{47}$ Kostof, A History of Architecture, 632.

${ }^{48}$ Hungerford, The Story of the Baltimore \& Ohio Railroad, volume 1, 295.

${ }^{49}$ Ibid.

${ }^{50}$ Brinkman, "Early History of Grafton,” 7 September 1929.

51 Ibid, 130.

52 Ibid, 217.

${ }^{53}$ Baltimore \& Ohio Rail Road Company Minute Book “H” (1856), 108.

${ }^{54}$ Brinkman, "Early History of Grafton," 7 September 1929. 
Resley had earlier been nominated to serve as agent for the Mozell and New Creek, Virginia, stations, but the $\mathrm{B} \& \mathrm{O}$ board of trustees passed over his approval for those positions. ${ }^{55}$

Numerous hotels and boarding houses also opened in Grafton and the surrounding area to accommodate rail passengers and crews. William Powell built a tavern and boarding house, and Peter Wolf opened the Old Virginia House in the late 1850s. ${ }^{56}$ By the time the Grafton Hotel was completed in 1857, Charles Creel had built a blacksmith shop. Mrs. Anna Dunk opened a bakery and grocery store. James Cassel opened a general store, and Louis Wittman and G.W. Stanley had both started tailor shops. ${ }^{57}$ Mrs. Annie Burns operated a three-story boarding house and tavern one block from the railroad yards. ${ }^{58}$ Hired to head the Grafton Hotel's bakery in 1857 was John George Brinkman. A young recent immigrant from Germany working as a baker in Baltimore, he made Grafton his home after accepting the job, later opening his own shop on Elizabeth (Main) Street. ${ }^{59}$ The Grafton Hotel contributed only in part to private entrepreneurial efforts at Grafton as other prospects grew out of the presence of the railroad. John M. Thayer of Oakland, Maryland, for example, received the contract to grade and level an extension of the $\mathrm{B} \& \mathrm{O}$ rail yards at Grafton in 1858 as the $\mathrm{B} \& \mathrm{O}$ prepared for taking over the NVRR. He contracted to clear timber from an area adjacent to present-day downtown in preparation for B\&O construction crews. After completion, Thayer established a saw mill on the west bank of the Tygart River across from Grafton and promptly engaged in the lumber business. ${ }^{60}$ Francis Flanagan arrived at Grafton in 1858 via the

\footnotetext{
${ }^{55}$ Baltimore \& Ohio Rail Road Company Minute Book “G” (1857), 47.

${ }^{56}$ Ibid, 4 September 1929.

${ }^{57}$ Ibid.

${ }^{58}$ Ibid.

${ }^{59}$ Brinkman, "Early History of Grafton," 7 September 1929.

${ }^{60}$ Ibid, 9 September 1929.
} 
B\&O Railroad after emigrating from his native Ireland. He established a blacksmith and wagonbuilding shop on Grafton's east side across Main Street from the present-day Willard Hotel and former B\&O passenger depot. ${ }^{61}$

As the community developed beyond the stage of a work camp for B\&O construction crews and operation workers, basic utilities also had to be developed. Among the first was a coal gas manufacturing plant for street and home lighting. Samuel Albright and John Miller constructed a plant for the refinement and distribution of illuminating gas in 1857. In addition to lighting the Grafton machine shops and Grafton Hotel, they placed the Grafton Illuminating Company's first street lamps along Main, Railroad, and Latrobe streets, where both local residents and railroad patrons could appreciate the modern amenities. ${ }^{62}$

Like the nation as a whole, Grafton's growth suffered setbacks during the financial panic of 1857. Two major railroad lines through Grafton did assuage some of the worst economic effects of the crisis, but its citizens were nonetheless reliant on the $\mathrm{B} \& \mathrm{O}$ for their living. Increased traffic in coal, iron, and produce after the main stem opened in 1853 had raised expectations and optimism. But the panic of 1857 frustrated not only B\&O company visions, it also shook public confidence in the promise of railroads to bring prosperity. Indeed, D. Morier Evans, in a contemporary history, observed a growing distrust of railroad companies among many Americans as being greed-driven and corrupt, adding to an already apprehensive national business climate. ${ }^{63}$

Tensions mounted in April 1857 when strikers at Martinsburg, Virginia, and Ellicotts Mills,

${ }^{61}$ A History of Taylor County, West Virginia, 216.

${ }^{62}$ Brinkman, "History of Taylor County," 29 May 1939.

${ }^{63}$ D. Morier Evans, The History of the Commercial Crisis, 1857-1858 (New York: Burt Franklin, 1860, 1969), 101. 
Maryland, closed the main stem in protest of wage decreases. Governors called the state militia in each case to maintain commerce ${ }^{64}$ However, system-wide discord did not affect $\mathrm{B} \& \mathrm{O}$ workers at Grafton, or at least, not to the extent that work halted. This may have been due to trepidation over losing well paying jobs, the management skills of William H. Freeman, Jr., company agent at Grafton, or a sense of loyalty among community residents toward the railroad. ${ }^{65}$

Perhaps many workers would have confessed mixed loyalties, but the fate of most of Grafton's laborers and families rested with the fortunes of the B\&O Railroad. Few alternatives for wage labor existed in Grafton during the late 1850 s, with the $\mathrm{B} \& \mathrm{O}$ offering the vast majority of job opportunities. Although generally difficult and dangerous, work with the $\mathrm{B} \& \mathrm{O}$ was an honorable pursuit that paid well. When the average American earned about $\$ 300$ annually, common laborers earned $\$ 1$ a day with the $\mathrm{B} \& \mathrm{O} .{ }^{66}$ Depending on seniority, carpenters, blacksmiths and machinists made approximately $\$ 1.50$ daily. Henry Leuthke's stone masons earned $\$ 2$ daily while laying the Grafton depot's platform. Train watchmen, the men who guarded grade crossings for moving trains, earned $\$ 30$ per month. Passenger train firemen, or the locomotive's boiler stoker, drew $\$ 40$ a month while passenger conductors made $\$ 62.50$ a month. Telegraphers earned up to $\$ 50$ monthly. Station agents, such as James K. Smith or William H. Freeman, collected as much as \$166.66 monthly. ${ }^{67}$

\footnotetext{
${ }^{64}$ Hungerford, The Story of the Baltimore \& Ohio Railroad, volume 1, 321.

${ }^{65}$ Baltimore \& Ohio Rail Road Company Minute Book "H" (1857), 218, 233.

${ }^{66}$ Taylor, The Transportation Revolution, 393.

${ }^{67}$ List of Officers \& Employees in the Service of the Baltimore \& Ohio R. Road Company, 1-98 passim.
} 


\section{Riding the Rails}

A wave of excitement seemed to wash over American society with each new story of industrial progress while the $\mathrm{B} \& \mathrm{O}$ completed its main stem. To satisfy intense curiosity about a new technology, and to proudly trumpet their accomplishments, railroad companies regularly sponsored special excursion trains. From these, artists and reporters could afford an immediate and personal connection between the public and the railroads. On the first of June 1858, shortly after completing the Kingwood Tunnel, one of the most important engineering projects on the main stem, $\mathrm{B} \& \mathrm{O}$ officials sponsored an excursion train celebrating a new route to the west. So many people wanted to see this new transportation marvel first hand that safe capacity of the train was labored, if not exceeded. Such prestigious Americans as Secretary of State Lewis Cass, historian and statesman George Bancroft, newspaper editor Charles Dana, and navy Commodore Mathew Perry joined the adventure. ${ }^{68}$ In addition to a plethora of politicians, business notables, journalists and artists, a number of minor dignitaries invited themselves along for the ride, totaling over fifty passengers. A locomotive, tender and six small cars comprised the train. Guests rode in one passenger car and one combination passenger and smoking car behind two cars converted for common work spaces. A dining and saloon car and a combination photography studio and baggage car rounded out the remainder of the train. ${ }^{69}$

The special junket boarded at Baltimore. Captain Rawlings, the train's conductor bearing the proper title of the time for the person in charge of the train, received instructions to stop any place along the line that passengers might request for sightseeing, sketching, or quiet contemplation,

${ }^{68}$ Hungerford, The Story of the Baltimore \& Ohio Railroad, volume 1, 306.

${ }^{69}$ David Hunter Strother, "Artists Excursion Over the Baltimore and Ohio Rail Road," Harper's New Monthly Magazine, 19 (June 1859): 4, 6. 
causing confusion and delays to regular traffic that can easily be imagined. ${ }^{70}$ Yet, with its complete photographic laboratory, painting studio, rows of writing tables, as well as the usual amenities required for the guests' comfort including "springy sofas and a handsome piano-forte," the excursion helped preserve an important contemporary glimpse of scenes newly touched by railroads and industrial technology. ${ }^{71}$ Brantz Mayer, reporting on a similar excursion in 1856, called it a "wilderness of romantic disorder." ${ }^{72}$ Indeed, the vistas proved so electrifying that at the request of passengers, the train's crew affixed seats to the forward fender, or "cow catcher", of Engine 232, itself "a miracle of power, speed, and beauty."

A steady rain could not diminish the drama of the Allegheny Mountains, awe-inspiring technology, and admiration for the tenacity required of laborers to make the scene possible. ${ }^{74}$ But the most dazzling sights came on the leg between Keyser Ridge in western Maryland and Grafton. The train crested at the line's 2,638-foot apex at Altamont, Maryland. It then passed through the already world-famous 4,100-foot long Kingwood Tunnel, and over Tray Run Viaduct along the Cheat valley gorge, a sight so inspiring that it would later adorn the reverse side of the West Virginia state seal. Few easterners had ever seen the foreboding heart of northwestern Virginia, and its late spring scenery enkindled poetic refrain while somewhat overwhelming the senses. According to David Hunter Strother, the party became

occupied with the grandeur of the mountains; the awful gorge, deepening as we progressed, through which the savage river toiled and raged; the mossy rocks and

${ }^{70}$ Ibid, 6.

${ }^{71}$ Ibid.

${ }^{72}$ Mayer, “A June Jaunt,” 600.

${ }^{73}$ Strother, "Artists Excursion," 6, 13.

${ }^{74}$ Ibid, 14. 
groups of lofty firs near at hand, that gave the scene a Norwegian aspect; the silvery streamlets flashing through sombre thickets of evergreen; the gorgeous bouquets of azalia and mountain honey-suckle, that recalled the luxuriance of the tropics. ${ }^{75}$

Upon arriving at Grafton, many of the party boarded a thirty-foot-long steamboat for a sunset cruise on the Tygart River before retiring for the evening. By then, the weather had turned warm and sunny, and the river cruise offered respite from the hectic pace of rail travel. Gentle puffing from the boat's tiny engine, the placid river, and cool mountain breezes lulled the passengers as they sat under the boat's awning, drinking in the serenity and rich foliage. After dinner and impromptu musical entertainment at the hotel, excursionists turned in for the evening, anticipating resuming the adventure the next day. ${ }^{76}$ Unfortunately, sleeping arrangements were even more crowded than the train. With its regular complement of patrons, the newly opened Grafton Hotel had room enough only for the ladies in the entourage, the gentlemen being forced to sleep on benches, cots, and makeshift bunks. $^{77}$

After a large, sumptuous breakfast at the Grafton Hotel the group continued its journey. They next stopped at Valley Falls, seven miles northwest of Grafton on the Tygart River. Postmaster W.B. Fetterman, son of Washington and Sarah Fetterman, joined local residents in welcoming the train. The town, lying on the border line between Taylor and Marion counties, took its name from dual waterfalls in the Tygart. The setting caused Strother to describe the falls as "one of the most exquisite bits of scenery which had yet met [his] eyes." ${ }^{78}$

After the excursion, rail traffic along the main stem increased, leading to ever growing traffic

\footnotetext{
${ }^{75}$ Ibid, 14.

${ }^{76}$ Ibid, 15.

${ }^{77}$ Hungerford, The Story of the Baltimore \& Ohio Railroad, volume 1, 307.

${ }^{78}$ Strother, "Artists Excursion," 16.
} 
levels through Grafton. The effect on the community ranged from population growth to an expansion of mercantile concerns. By the autumn of 1860, on the eve of the Civil War, Grafton was a small but prosperous community whose only major industry was the railroad. This proved ample, though, for a town of 891 inhabitants, including six free blacks. ${ }^{79}$

With completion of the Parkersburg Branch, Grafton became very important to a national railroad system, which in turn gave it a tremendous commercial advantage and impetus for growth. ${ }^{80}$ Such things as iron stoves and farm equipment, not easily or cheaply carried by wagon, became widely available to Grafton residents through rail transport.

Topography and circumstances drew two railroads to Grafton and the gently rolling terrain, water courses, and flat open land preferred for railroad construction. Although not a destination, assets like coal, iron ore, timber, and rich farm lands helped draw the Baltimore \& Ohio main stem and Parkersburg Branch to Taylor County with the certainty that more resources would come from the Ohio River valley. The Grafton to Parkersburg line also provided a more direct western route for the $\mathrm{B} \& \mathrm{O}$ than its main stem to Wheeling. Employment with the railroad accounted for over 250 laborers and skilled artisans in the community, with wages better than a young man of average education might expect outside of large cities.

The railroad also helped introduce professional architecture. New techniques using balloonframe construction had replaced the post-and-beam, or post-and-girt method used to build the log

${ }^{79}$ Population of the United States in 1860 (Washington: Government Printing Office, 1864), 519.

${ }^{80}$ Dilts, The Great Road, 328, 441. 
houses of the earliest pioneers. ${ }^{81}$ The process easily translated to building dwellings and businesses, and workers followed contemporary styles as much as practical to the extent of available saw mills, material, and capital. If owners could afford a bit of extravagance, houses could be simplified Georgian or Italianate, some examples of which survive to this day, and can readily be seen in and around Grafton. ${ }^{82}$ Until construction of the Grafton Hotel in 1856, buildings were haphazard but durable..$^{83}$

Grafton embodied a conflicting mix of permanence and restless transience. The community reflected a time of modern industrialization emphasizing speed and efficiency, as well as frontier aspirations to tame the wilderness and build new communities. Railroad administrators and on-site artisans who had laid out Grafton meant it to be an enduring place. By 1860, Grafton's yards comprised 16,558 feet of track, or three and one-tenths miles laid at the mouth of Three Forks Creek. ${ }^{84}$ As a railroad town that also encompassed the turnpike town of Fetterman, mobility characterized the community of Grafton, but so did the phenomenon of setting down roots.

About one-third of Grafton's population could be traced to the influx of Irish railroad workers who stayed on to make a home by 1860 . Longer established families, such as the Luzadders, sold land for settlement and commercial ventures to new arrivals such as Thomas

${ }^{81}$ McAlester, A Field Guide to American Houses, 82-6; Balloon-framing is the technique known in modern house construction, wherein a framework of relatively lightweight two-inch by four-inch or larger lumber forms an interior skeleton, upon which an outer sheathing is applied.

${ }^{82}$ Ibid, 12-4, 80-90; Poppeliers, What Style Is It?, 40-9; for an examination of evaluating houses and other structures for historical significance see Barbara J. Howe, et al., Houses and Homes: Exploring Their History (Nashville, Tenn.: American Association for State and Local History, 1987), 14-8, 24-6, 81-5, 97-124.

${ }^{83}$ Boorstin, The Americans, 148-52; McAlester, A Field Guide to American Houses, 36-8.

${ }^{84}$ Thirty Fourth Annual Report BORR (1860), 134, 138. 
McGraw, John Doonan, and many others brought to the Tygart River valley by the Baltimore \& Ohio Railroad. $^{85}$

Upon assuming controlling interest of the Northwestern Virginia Railroad in 1860, Baltimore \& Ohio administrators saw not only a machine shop at Grafton, but a rail line in far worse financial and physical condition than first realized. In the 1857 report to $\mathrm{B} \& \mathrm{O}$ stockholders, president Chauncy Brooks advised that even after assuming ownership of the land and NVRR structures at Grafton, the Northwestern Virginia Railroad still owed over $\$ 1,000,000$ to B\&O coffers from direct loans. ${ }^{86} \mathrm{~B} \& \mathrm{O}$ directors were aware that the NVRR was in disarray, but had been misled about the true condition of the road. Brooks reported that it required a "large force ... to place it in safe working order. The [repair and maintenance] expenditures have been necessarily large, and have very heavily exceeded the estimates furnished to this Company [the $\mathrm{B} \& \mathrm{O}] .{ }^{87}$ Nonetheless, a rail line to Wheeling and eastern Ohio, as well as a branch line to Parkersburg and the lower Ohio River valley had been secured.

Due to the railroad, Grafton needed approximately seven years to become a functional commercial town, unlike Pruntytown and Fetterman, which grew slowly during the turnpike era of the 1830 s and 1840 s. B\&O administrators, concerned with rail trade from the Ohio and Mississippi rivers, first provided proper facilities for locomotives and rolling stock, only afterwards bolstering local commercial prospects that would promote community. ${ }^{88}$ Grafton's citizens viewed the railroad

${ }^{85}$ For an examination of local elites of the region see L. Diane Barnes, "Avenues to a Market Economy: Harrison County, West Virginia, to 1860" (Master's thesis, West Virginia University, 1995), 40-5 and 83-104.

86 Thirty First Annual Report BORR (1857), 6.

${ }^{87}$ Ibid, 10.

${ }^{88}$ Reps, The Making of Urban America, 389. 
as a benefit to the region because, at long last, large-scale transportation improvements had arrived for western Virginians. Business operators in Grafton could draw on markets outside Virginia's borders. By 1852, although still unfinished, the B\&O main stem had already carried over 7,000,000 pounds of salt, close to 3,000,000 pounds of coffee, over 2,200 tons of sugar, and about 20,000,000 pounds of manufactured goods, making the company $\$ 808,992$ in profit. ${ }^{89}$ By 1860 , the company was solvent and "free from floating debt." 90 Stockholder reports of that year show total expenditures and revenues rather than tonnages, but the main stem and Parkersburg Branch had reaped $\$ 1,970,405$ in profits, and could claim an additional $\$ 26,375,726$ worth of equipment, rights-ofway, and real estate for the two lines. ${ }^{91}$

A connection point between two railroads, and the commensurate opportunities it presented, gave Grafton's entrepreneurs, wage laborers, and surrounding farmers the necessary entrée to a larger economy on a national scale. The 1850 United States census showed 5,367 residents of Taylor County, Virginia. ${ }^{92}$ Ten years later, the census tallied 7,351 residents. ${ }^{93}$ As Taylor County was not formed until 1844, and the residents of that area were divided among three other counties, it is difficult to determine population before the 1850 census. But with a jump of nearly 2,000 residents

${ }^{89}$ Twenty Sixth Annual Report BORR (1852), tables A and K.

${ }^{90}$ Thirty Second Annual Report BORR (1860), 1; Black's Law Dictionary, Fifth edition, defines floating debt as "liabilities (exclusive of bonds) payable on demand or at an early date; e.g. accounts payable, bank loans."

${ }^{91}$ Thirty Second Annual Report BORR (1860), 3, table A.

92 The Seventh Census of the United States (1850), 257.

93 The Eighth Census of the United States (1860), 522. 
in ten years in the rugged mountains of western Virginia during the same time frame of the Baltimore \& Ohio and Northwestern Virginia railroads' completion, and over half of those residing in Grafton, the railroad must be acknowledged as the key factor in growth. 


\section{Conclusion}

The ages of gold, of silver, of brass, and iron, as described by the poets, are past. The present is the age of steam. ${ }^{1}$

When considering the history of the Baltimore \& Ohio Railroad, especially its earliest years, our nation's heritage can be seen in a microcosm. Fast, cost effective commercial and personal transportation became one of the largest and most enduring industrial era projects for the new American nation. Competition among east coast cities and the need to remunerate investors spawned an urgency among B\&O officials, like those of the Pennsylvania Railroad, the Erie line in New York state, and others, to build rapidly. "It was most important to arrive there first, or, if not first, then as soon as possible. It was haste that decisively shaped the technology of American travel," observed historian Daniel Boorstin. ${ }^{2}$ However, in pursuing their goal, the B\&O Railroad faced the spine of the Allegheny Mountains rising like a monstrous wall.

Being the first major American railroad to directly link a city to markets two to three hundred miles away, the Baltimore \& Ohio brought numerous isolated communities into a national transportation system. Construction of the main stem also gave workers a broad range of experience. Such notable civil engineers as Albert Fink and Benjamin H. Latrobe, Jr., came from its ranks. Laborers from Ireland and America made possible the engineer's plans. Baltimore \& Ohio operations became so successful at meeting technological needs that the $\mathrm{B} \& \mathrm{O}$ became known as America's "railroad university."3

${ }^{1}$ Strother, “Artists Excursion," 1.

${ }^{2}$ Boorstin, The Americans, 97.

${ }^{3}$ Frey, Railroads in the Nineteenth Century, xv-xvi; Hungerford, The Story of the Baltimore \& Ohio Railroad, volume 1, 111-2. 
Mid-nineteenth century Grafton proved to be a prototype of later railroad towns. The Northwestern Turnpike carried the first wave of settlers into a remote and inhospitable region, but railroads forever transformed David Tygart's river valley into a transportation hub, setting the stage for future industrialization. The expansion of America's market economy through improved transportation in the mid-nineteenth century touched countless communities. By the end of the nineteenth century, Grafton had grown into a thriving town based on the coal, glass, and timber industries. The railroad continued to play a central role, with Grafton the second most important division point for the Baltimore \& Ohio Railroad after Cumberland, Maryland.

In addition, steam railroads changed the social complexion of Taylor County. Irish railroad workers augmented the already settled Scots-Irish, and the rail line brought more foreign emigrants after the Civil War. "The power of railroads and steam has changed the whole aspect of things," wrote James D.B. DeBow in $1853 .{ }^{4}$ The railroad era brought changes for ordinary citizens, as well. For example, the Northwestern Virginia Railroad Company constructed a public boardwalk in 1857 or 1858 along Railroad Street in Grafton's commercial district, providing an unobstructed view of the new marvel at work. The boardwalk created a mode of social interaction highlighted by a rave for promenading the latest European fashions purchased from New York and carried by railroads. ${ }^{5}$ As a major junction point for one of the largest railroads in the country, Grafton occasionally took on national importance. In the opening phases of the Civil War, Fetterman and Grafton drew very early organized fighting due to the Northwestern Turnpike bridge and Baltimore \& Ohio Railroad. Confederate forces targeted the Tygart River valley, among other places, to disrupt

\footnotetext{
${ }^{4}$ DeBow, The Industrial Resources of the Southern and Western States, volume 2, 438.

${ }^{5}$ Brinkman, "Early History of Grafton," 4 September 1929.
} 
northern lines of communication, supply, and troop movement. At the end of April 1861, a force under Major F.M. Bovkin moved to control Grafton and its all-important railroad junction. Union General George R. Latham thwarted Bovkin's efforts, and his forces occupied Grafton by the middle of May. ${ }^{6}$ Within days of hostilities around Grafton, newspaper warnings appeared in Wheeling, Baltimore, and elsewhere that the postal and military use of the B\&O Railroad would be disrupted by southern detachments, frightening patrons and curtailing commerce. ${ }^{7}$ To stem trouble, $\mathrm{B} \& \mathrm{O}$ president John W. Garrett offered to transport rebelling Virginia troops as well as Union forces, but United States Secretary of War Simon Cameron promised that charges of treason would be brought if he carried out his offer. ${ }^{8}$

Confederate forces made a second attempt to occupy Grafton in August 1861. On the thirteenth, fifty men of the Union 4th Virginia regiment held off approximately 200 southern soldiers for the last fighting seen around the town. During April 1863, raids under Confederate Generals John D. Imboden and William E. Jones against the $\mathrm{B} \& \mathrm{O}$ main stem in Virginia and rail junction at Grafton, although unsuccessful, underscored War Department concerns. ${ }^{9}$ Their mission to burn bridges, collapse tunnels, and destroy Union rail links as a tactical maneuver proved that the $\mathrm{B} \& \mathrm{O}$ posed a threat to the Confederacy and had to be protected. Union garrison troops occupied the town, surrounding countryside, and major features of the $\mathrm{B} \& \mathrm{O}$, such as bridges and tunnels, for the

${ }^{6}$ George A. Shingleton, Grafton and Taylor County During the Civil War Days and Points of Interest (Taylor County Historical Society, 1961), 4; Brinkman, "History of Taylor County," 1 June 1939; A History of Taylor County, West Virginia, 8.

${ }^{7}$ William Prescott Smith, $B \& O$ in the Civil War, edited by William E. Bain (Denver: Sage Books, 1966), 33-5.

${ }^{8}$ Stover, History of the Baltimore and Ohio Railroad, 103.

${ }^{9}$ Festus P. Summers, “The Jones-Imboden Raid,” West Virginia History, 47 (1988): 5362. 
remainder of the war.

Railroads brought a new dimension to war, and fighting over the B\&O placed Grafton's citizenry in harm's way, revealing an adverse aspect of improved transportation that Taylor County entrepreneurs and investors could not have anticipated. Less than ten years after commerce first rolled between Baltimore and Wheeling, the $\mathrm{B} \& \mathrm{O}$ Company found, to their distraction, that they owned a strategic commodity contributing to the fate of the nation in a way they had not envisioned.

After 1863, Grafton residents saw little of the war, save for garrison troops and the aftermath of fighting. The Union War Department established a hospital at Grafton, and Dr. Thomas Kennedy volunteered for the job of United States Army examining surgeon. As a northerner, dedicated Republican, and patriot, Kennedy, also served as Grafton's mayor during the Civil War. In the 1870 s, Kennedy would serve as mayor of West Grafton..$^{10}$

The Civil War increased traffic on the $\mathrm{B} \& \mathrm{O}$, commensurately boosting the number of people and amount of commerce passing through Grafton. Industrialization came to Taylor County with the railroad and confirmed for local politicians and merchants that business success other than farming could be realized, even in remote communities. Before the Civil War, only small amounts of timber, coal, and iron ore supplied a local market. After the war, the B\&O Railroad transported massive amounts of timber and coal to customers in a greatly expanded area.

Among the many benefactors of Baltimore \& Ohio Company success were commercial interests in Taylor County. Isolation in the mountains of western Virginia became less formidable after railroads replaced turnpikes as the most advanced transportation technology available. By their

${ }^{10}$ Biographical and Portrait Cyclopedia of Taylor County, 19-20; Dr. Thomas Kennedy obituary, The Grafton Sentinel, 1 October 1881. 
nature, turnpikes could provide only the barest of necessities or infrequent luxury items for people served by them, proving to be generally unprofitable ventures in America by 1840, although they still comprised a significant component of most state and regional transportation systems until the late 1860s and 1870s. ${ }^{11}$ By the 1860 s, railroads had reduced stage coach operators and teamsters from dominion over America's highways to providing short distance feeder service for railroad lines. Railroads from both the upper and lower Ohio River valley converged at Grafton, almost guaranteeing prosperity to many people moving to the newly formed town.

Numerous people came to Grafton because of the B\&O Railroad, such as Thomas McGraw who became a community leader and town administrator in the late 1850s, assuming the mantle of trustee for Grafton, or a town administrator. Tragically, in his mid-fifties, McGraw learned that he suffered from cancer. He died at age 55 and was buried on a hilltop near his mother in the Catholic Cemetery along the Northwestern Turnpike. ${ }^{12}$ John George Brinkman, first drawn to Grafton as the bakery manager of the B\&O's Grafton Hotel, struck out on his own after the Civil War. Brinkman relocated twice within the town, finally occupying a three-building commercial block in the 1870 s, which he personally financed. His eldest son, Charles, while accomplishing great strides in his own right, became a local historian recording much of Taylor County's story. ${ }^{13}$ John Doonan, another resident who arrived at Grafton with the railroad, took elected office early in Grafton's history, serving one term on the city council. Although a staunch Democrat, Doonan clearly preferred the world of business, maintaining his store and commercial properties, and becoming director of the

\footnotetext{
${ }^{11}$ Taylor, The Transportation Revolution, 26-8.

${ }^{12}$ A History of Taylor County, West Virginia, 306.

${ }^{13}$ Ibid, 169.
} 
First National Bank of Grafton when it formed in the 1870s. ${ }^{14}$ Actually, in relating local legend, historian Charles Brinkman identified Grafton's St. Johns and Elizabeth (Main) streets as named for Doonan and his wife. ${ }^{15}$ Before his death in 1911, Henry Compton, also a former B\&O employee, had accrued a farm on Whiteday Creek north of Blueville, three houses, two city lots, a controlling share in the Grafton Gas and Electric Light Company, and over $\$ 2,000$ in cash. ${ }^{16}$ All had come to Grafton as employees of the B\&O Railroad.

Efforts of local settlers and entrepreneurs living far from the mountains of Virginia merged to alter forever the social, political, and economic development of an entire region through successive transportation phases. Grafton residents who had lived through the frenetic decade of the 1850s saw railroads convert sparsely inhabited farm lands into a smokey railroad town. With completion of the B\&O line between the east coast and the Ohio River valley, its citizens also saw a town straddling two key routes to the American west, becoming one of the most important railroad towns in the pre-Civil War period. The B\&O main stem and Parkersburg Branch had done what some people considered impossible only a generation before, forged an all-weather, high speed land route through the Allegheny Mountains. Completing the Baltimore \& Ohio Railroad involved cooperation of political and economic interests on the local, state, and national levels. The success of those interests directly led to the town of Grafton, while almost immediately redefining land use and the social character of the Tygart River valley.

${ }^{14}$ Charles Brinkman papers, "Grafton Newspaper Clippings-1883-1927,” WVRHC; “J.A. Doonan," The Grafton Eagle Sentinel, Historical Edition, November 1889, 5; Biographical and Portrait Cyclopedia of Taylor County, 13-4.

${ }^{15}$ Brinkman, "Early History of Grafton," 4 September 1929.

${ }^{16}$ TCCC, Will Book 2, 401-3. 


\section{BIBLIOGRAPHY}

Primary Sources

Acts of the General Assembly of Virginia. Richmond: Thomas Ritchie, Printer to the Commonwealth, 1825-1860.

Address of Thomas Swann to the Directors of the Baltimore and Ohio Rail-Road Company on the Importance of an Early Completion of Their Road to the Ohio River Delivered 14 November 1849. Baltimore: James Lucas, 1849.

Address of Thomas Swann on the Parkersburg Railroad Delivered 28 January 1852. Baltimore: John Murphy \& Co., 1852.

The American Union (Morgantown, Va.), 1857.

Annual Reports to the Stockholders of the Baltimore \& Ohio Rail Road Company. Baltimore: James Lucas and E.K. Deavers, 1836-1860.

Annual Reports of the Virginia Board of Public Works to the General Assembly of Virginia. Richmond: Samuel Shepherd, 1827-1860.

Baltimore \& Ohio Rail Road Company Minute Books F, G, and H, 1849-1860.

Birkbeck, Morris. Notes on a Journey in America. Ann Arbor: University Microfilms, 1966.

Bowers, Claude G., editor. The Diary of Elbridge Gerry, Jr. New York: Brentano's, 1927.

Charleston, West Virginia. West Virginia Division of Archives and History. Virgil Lewis Papers.

Clarksburg Enquirer, 1827, 1830.

Cooper's Clarksburg Register, 1857.

The Fairmont True Virginian, 1856, 1857.

Fairmont, West Virginia. Marion County Clerk of Courts, Will Book number 1.

Fordham, Elias Pym. Personal Narrative of Travels in Virginia, Maryland, Pennsylvania, Ohio, Indiana, Kentucky; and of a Residence in the Illinois Territory, 1817-1818. Cleveland, Ohio: The Arthur H. Clark Company, 1906. 
Gallatin, Albert. Report of the Secretary of the Treasury on the Subject of Public Roads \& Canals, 1808. (Reprints of Economic Classics, Augustus M. Kelly, Publishers, New York, 1968).

The Grafton Guardian, 1860.

The Grafton Sentinel, 1876.

Grafton, West Virginia, Taylor County Court House, County Clerk's Office. Deed Books 1-4. . Land Books.

. Will Books.

The Harrison Republican (Clarksburg, Va.), 1849.

Hening, William Waller. The Statutes at Large: Being a Collection of All the Laws of Virginia, from the First Session of the Legislature, in the Year 1619. Richmond: W.W. Gray, 1730-1821.

Kanawha Republican (Charleston, Va.), 1844.

Latrobe, John H.B. "Personal Recollections." A lecture delivered before the Maryland Institute, 23 March 1868. Baltimore: The Sun Book and Job Printing.

List of Officers and Employees in the Service of the Baltimore \& Ohio R. Road Company with their Occupations and Salary. Baltimore: James Lucas and Son, 1855.

Majority and Minority Reports of the Special Committee on the Subject of the Baltimore and Ohio Railroad. Virginia General Assembly Document Number 78, 1852-3.

Morgantown, West Virginia. Monongalia County Clerk's Office. Monongalia County Land Book 1828 and 1842 to 1848 . . Monongalia County Deed Books Old Series 14 and 17.

Morgantown, West Virginia. West Virginia University. West Virginia and Regional History Collection. Charles Brinkman Papers.

. Clayton and Fenton Collection.

. Haymond Family Papers. 
. William Robinson Papers.

Parkersburg Gazette, 1841, 1842.

Thwaites, Reuben Gold, editor. Sketches of a Tour to the Western Country by Fortescue Cuming. Cleveland, Ohio: The Arthur H. Clark Company, 1904.

United States Bureau of the Census. Manuscript Census Schedules, Taylor County, Virginia. Washington, D.C., 1850, 1860. Microfilm.

. Abstract of the Returns of the Fifth Census of the United States. Washington: Duff Green, 1832.

. Statistics of the United States of America: Sixth Census. Washington, D.C.:

Government Printing Office, 1841.

. The Seventh Census of the United States: 1850. Washington, D.C.: Government Printing Office, 1853.

. Statistical View of the United States: Compendium of the Seventh Census.

Washington, D.C.: Government Printing Office, 1854.

. Statistics of the United States in 1860. Washington, D.C.: Government Printing Office, 1864.

. Manufactures of the United States in 1860. Washington, D.C.: Government Printing Office, 1865.

. Population of the United States in 1860. Washington, D.C.: Government Printing Office, 1864.

. The Ninth Census of the United States: 1870. Washington, D.C.: Government Printing Office, 1872.

. Statistical View of the United States: Compendium of the Ninth Census. Washington, D.C.: Government Printing Office, 1872.

Wheeling Gazette, 1830, 1831.

Wheeling Times and Advertiser, 1844.

Wheeling, Virginia, Semi-Weekly Argus, 1845. 
Western Enquirer (Clarksburg, Va.), 1832.

The Western Virginian (Charleston, Va.), 1828.

White's New County and District Atlas of the State of West Virginia. Philadelphia: M. Wood White, 1873.

\section{Secondary Sources}

Adams, Florence J. Footsteps: A Story of Grafton, Taylor County West Virginia. Parsons, W.V.: McClain printing Company, 1986.

Alvarez, Eugene. Travel on Southern Antebellum Railroads, 1828-1860. University, Alabama: The University of Alabama Press, 1974.

Ambler, Charles Henry. A History of West Virginia. New York: Prentice-Hall, 1933. . Sectionalism in Virginia From 1776 to 1861. New York: Russell and Russell, 1964. . West Virginia: The Mountain State. New York: Prentice-Hall, Inc., 1940.

Appleby, Joyce. Capitalism and a New Social Order: The Republican Vision of the 1790s. New York: New York University Press, 1984.

Bain, William E., editor. $B \& O$ in the Civil War: From the Papers of William Prescott Smith. Denver: Sage Books, 1966.

Beeman, Richard R. The Old Dominion and the New Nation, 1788-1801. Lexington: The University Press of Kentucky, 1972.

Bell, Colin and Howard Newby. Community Studies: An Introduction to the Sociology of the Local Community. New York: Praeger Publishers, 1972.

Bender, Thomas. Toward an Urban Vision: Ideas and Institutions in Nineteenth Century America. Lexington, Kentucky: The University Press of Kentucky, 1975.

Biographical and Portrait Cyclopedia of Monogalia, Marion and Taylor Counties, West Virginia. Philadelphia: Rush, West \& Company, 1895.

Bradfield, Richard Maitland. A Natural History of Associations: A Study in the Meaning of Community. 2 volumes. New York: International Universities Press, 1973. 
Brinkman, Charles. The History of Taylor County. Grafton, West Virginia: Taylor County Historical and Genealogical Society, 1989.

Brooks, A.B. West Virginia Geological Survey. Morgantown: Acme Publishing, 1910.

Brooks, William E. "The Northwest Turnpike and West Virginia." A Newcomen Society address. Princeton, N.J.: Princeton University, 1943.

Buder, Stanley. Pullman: An Experiment in Industrial Order and Community Planning. New York: Oxford University Press, 1967.

Callahan, James Morton. Semi-Centennial History of West Virginia. Semi-Centennial Commission of West Virginia, 1913.

Christenson, James A. and Jerry W. Robinson, Jr., editors. Community Development in America. Ames: Iowa State University Press, 1980.

Chudacoff, Howard P. Mobile Americans: Residential and Social Mobility in Omaha, 18801920. New York: Oxford University Press, 1972.

Core, Earl L. The Monongalia Story: A Bicentennial History. Parsons, W. Va.: McClain Printing Company, 1979.

Cronon, William. Changes in the Land: Indians, Colonists, and the Ecology of New England. New York: Hill and Wang, 1983.

Davis, Dorothy. History of Harrison County West Virginia. Clarksburg, West Virginia: American Association of University Women, 1970.

DeBow, James D.B. The Industrial Resources, Etc., of the Southern and Western States. 3 volumes. New Orleans: Merchants’ Exchange, 1853.

. Statistical View of the United States. Washington: A.O.P. Nicholson, 1854.

DeHass, Wills. History of the Early Settlement and Indian Wars of Western Virginia. Wheeling, W.V.: H. Hoblitzell, 1851.

Dilts, James D. The Great Road: The Building of the Baltimore and Ohio, the Nation's First Railroad, 1828-1853. Stanford, California: Stanford University Press, 1993.

Doddridge, Joseph. Notes on the Settlement and Indian Wars. Pittsburgh, Pa.: John S. Ritenour and William T. Lindsey, 1912. 
Douglas, George H. All Aboard!: The Railroad in American Life. New York: Smithmark Publishers, 1996.

. Rail City: Chicago, USA. San Diego: Howell-North Books, 1981.

Dunaway, Wilma A. The First American Frontier: Transition to Capitalism in Southern Appalachia, 1700-1860. Chapel Hill: The University of North Carolina Press, 1996.

Evans, D. Morier. The History of the Commercial Crisis, 1857-58, and the Stock Exchange Panic of 1859. New York: Burt Franklin, 1860, 1969.

Faragher, John Mack. Sugar Creek: Life on the Illinois Prairie. New Haven: Yale University Press, 1986.

Fogel, Robert William. Railroads and American Economic Growth: Essays in Econometric History. Baltimore: Johns-Hopkins Press, 1964.

Frey, Robert L., editor. Encyclopedia of American Business History and Biography. Railroads in the Nineteenth Century. New York: Bruccoli Clark Layman, Inc., 1988.

Grossman, Joel B. and Richard S. Wells, editors. Constitutional Law and Judicial Policy Making. New York: John Wiley and Sons, 1972.

Gutman, Herbert G. Work, Culture, and Society in Industrializing America: Essays in American Working-Class and Social History. New York: Vintage Books, 1966, 1977.

Hahn, Steven and Johnathan Prude, editors. The Countryside in the Age of Capitalist Transformation: Essays in the Social History of Rural America. Chapel Hill: The University of North Carolina Press, 1985.

Hahn, Steven. The Roots of Southern Populism: Yeoman Farmers and the Transformation of the Georgia Upcountry, 1850-1890. New York: Oxford University Press, 1983.

Handlin, Oscar and John Burchard. The Historian and The City. Cambridge, Massachusetts: Massachusetts Institute of Technology Press and Harvard University Press, 1963.

Handlin, Oscar and Mary F. Handlin. The Wealth of the American People: A History of American Affluence. New York: McGraw-Hill Book Company, 1975.

Hawke, David Freeman. Nuts and Bolts of the Past: A History of American Technology, 17761860. New York: Harper and Row, 1988. 
Haymond, Henry. History of Harrison County, West Virginia. Morgantown, W.V.: Acme Publishing Co., 1910.

Henry, Robert Selph. This Fascinating Railroad Business. New York: The Bobbs-Merrill Co., 1946.

Hennen, Ray V. West Virginia Geological Survey: Marion, Monongalia and Taylor Counties. Wheeling, W.Va.: Wheeling News Litho., 1913.

Hicks, George L. Appalachian Valley. New York: Holt, Rinehart and Winston, 1976.

Hine, Robert V. Community on the American Frontier: Separate But Not Alone. Norman: University of Oklahoma Press, 1980.

Howe, Barbara J., Dolores A. Fleming, Emory L. Kemp, and Ruth Ann Overbeck. Houses and Homes: Exploring Their History. Nashville, Tenn.: American Association for State and Local History, 1987.

Hudson, John C. Plains Country Towns. Minneapolis: University of Minnesota Press, 1985.

Hulbert, Archer Butler. Historic Highways of America. Volume 1. Paths of the MoundBuilding Indians and Great Game Animals. Cleveland, Ohio: The Arthur H. Clark Company, 1902.

. Volume 12. Pioneer Roads and Experiences of Travelers. Cleveland, Ohio: The Arthur H. Clark Company, 1902.

Hungerford, Edward. The Story of the Baltimore \& Ohio Railroad, 1827-1927. New York: G.P. Putnam's Sons, 1928.

Jackson, Carlton. A Social History of the Scotch-Irish. Lanham, Maryland: Madison Books, 1993.

Jacobs, Timothy. The History of the Pennsylvania Railroad. New York: Smithmark Publishers, 1988, 1996.

Kemp, Emory L. A History of the Weston and Gauley Bridge Turnpike. A report for the United States Army Corps of Engineers, 1979.

Kostof, Spiro. A History of Architecture: Settings and Rituals. New York: Oxford University Press, 1985. 
Laurie, Bruce. Artisans Into Workers: Labor in Nineteenth-Century America. New York: The Noonday Press, 1989.

Leonard, Cynthia Miller, editor. The General Assembly of Virginia, June 30, 1619-January 11,1978: A Bicentennial Register of Members. Richmond: Virginia State Library, 1978.

Lewis, Ronald L. Transforming the Appalachian Countryside: Railroads, Deforestation, and Social Change in West Virginia, 1880-1920. Chapel Hill: The University of North Carolina Press, 1998.

McAlester, Virginia and Lee. A Field Guide to American Houses. New York: Alfred A. Knopf, 1984.

McGrane, Reginald Charles. The Panic of 1837: Some Financial Problems of the Jacksonian Era. New York: Russell \& Russell, 1965.

Marx, Leo. The Machine in the Garden: Technology and the Pastoral Ideal in America. New York: Oxford University Press, 1964.

Maury, M.F. and William M. Fontaine. Resources of West Virginia. Wheeling, W.V.: The Register Company, 1876.

Mitchell, Robert D. Commercialism and Frontier: Perspectives on the Early Shenandoah Valley. Charlottesville, Virginia: University Press of Virginia, 1977.

Mumford, Lewis. The City in History: Its Origins, Its Transformation, and Its Prospects. San Diego: Harcourt Brace and Company, 1961, 1989.

- The Culture of Cities. New York: Harcourt, Brace \& World, Inc., 1938.

. Technics and Civilization. New York: Harcourt, Brace \& World, Inc., 1963.

Myers, Sylvester. Myer's History of West Virginia. 2 volumes. Wheeling W.V.: The Wheeling News Lithograph Company, 1915.

Poppeliers, John C., S. Allen Chambers, Jr., and Nancy B. Schwartz. What Style Is It? New York: John Wiley and Sons, 1983.

Pred, Allan R. City-Systems in Advanced Economies: Past Growth, Present Processes and Future Development Options. New York: John Wiley and Sons, 1977.

. The Spatial Dynamics of U.S. Urban-Industrial Growth, 1800-1914. Cambridge, Massachusetts: The M.I.T. Press, 1966. 
. Urban Growth and City Systems in the United States, 1840-1860. Cambridge, Massachusetts: Harvard University Press, 1980.

Rasmussen, Barbara. Absentee Landowning and Exploitation in West Virginia 1760-1920. Lexington, Kentucky: The University Press of Kentucky, 1994.

Reid, John Phillip. An American Judge: Marmaduke Dent of West Virginia. New York: New York University Press, 1968.

Reps, John W. Cities of the American West: A History of Frontier Urban Planning. Princeton: Princeton University Press, 1979.

. The Making of Urban America: A History of City Planning in the United States. Princeton: Princeton University Press, 1965.

. Town Planning in Frontier America. Princeton: Princeton University Press, 1969.

Roebling, John A. "The Great Central Railroad from Philadelphia to St. Louis." American Railroad Journal Extra. A speech delivered to the Pittsburg Board of Trade. Philadelphia: 1847.

Schodek, Daniel L. Landmarks in American Civil Engineering. Cambridge: M.I.T. Press, 1988.

Seller, Charles. The Market Revolution: Jacksonian America: 1815-1845. New York: Oxford University Press, 1991.

Shaffer, Lynda Norene. Native Americans Before 1492: The Moundbuilding Centers of the Eastern Woodlands. Armonk, New York: M.E. Sharpe, Inc., 1992.

Sharp, James Roger. The Jacksonians versus the Banks: Politics in the States After the Panic of 1837. New York: Columbia University Press, 1970.

Sheriff, Carol. The Artificial River: The Erie Canal and the Paradox of Progress, 1817-1862. New York: Hill and Wang, 1996.

Shingleton, George A. Grafton and Taylor County During the Civil War Days and Points of Interest. Taylor County Historical Society, 1961.

Sjoberg, Gideon. The Preindustrial City, Past and Present. Glencoe, Illinois: The Free Press, 1960.

Smith, Merrit Roe and Leo Marx, editors. Does Technology Drive History?: The Dilemma of Technological Determinism. Cambridge, Massachusetts: MIT Press, 1994. 
Stave, Bruce M. The Making of Urban History: Historiography Through Oral History. Beverly Hills: Sage Publications, 1977.

Stilgoe, John R. Common Landscape of America, 1580 to 1845. New Haven: Yale University Press, 1982.

Stover, John F. History of the Baltimore and Ohio Railroad. West Lafayette, Indiana: Purdue University Press, 1987.

. Transportation in American History. (Publication No. 75) Washington, D.C.: The American Historical Association, 1970.

Sydnor, Charles S. "Political Leadership in Eighteenth-Century Virginia." A lecture delivered before the University of Oxford. Oxford: The Clarendon Press, 1951.

Taylor County Historical and Genealogical Society. A History of Taylor County West Virginia. Grafton, W.V.: Taylor County Historical and Genealogical Society, Inc., 1986.

Taylor, George Rogers. The Transportation Revolution, 1815-1860. Armonk, New York: M.E. Sharpe, Inc., 1951.

Tetrick, W. Guy, editor. Census Returns of Barbour and Taylor Counties (West) Virginia for 1850. Clarksburg, W.Va.: W. Guy Tetrick, 1932.

Trelease, Allen W. The North Carolina Railroad, 1849-1871, and the Modernization of North Carolina. Chapel Hill: The University of North Carolina Press, 1991.

Trigger, Bruce G. and Wilcomb E. Washburn, editors. The Cambridge History of the Native Peoples of the Americas. Volume 1, North America. New York: Cambridge University Press, 1996.

Uselding, Paul John. Studies in the Technological Development of the American Economy During the First Half of the Nineteenth Century. Dissertations in American Economic History, Stuart Bruchey, advisory editor. New York: Arno Press, 1975.

Vance, James E. The North American Railroad: Its Origin, Evolution, and Geography. Baltimore: The Johns Hopkins University Press, 1995.

Ward, James A. Railroads and the Character of America, 1820-1887. Knoxville, Tennessee: University of Tennessee Press, 1986.

White, I.C. West Virginia Geological Survey. Volume 5. A.B. Brooks, Forestry and Wood Industries. Morgantown, W. Va.: Acme Publishing Company, 1910. 
. West Virginia Geological Survey. Ray V. Hennen and David B. Reger. Marion, Monongalia, and Taylor Counties. Wheeling, W. Va.: Wheeling News Lithograph Company, 1913.

Williams, John Alexander. West Virginia and the Captains of Industry. Parsons, W.V.: McClain Printing Company, 1976.

Winchester, Paul. The Baltimore \& Ohio Railroad. 2 volumes. Baltimore: The Maryland County Press Syndicate, 1927.

Winner, Langdon. Autonomous Technology: Technics-Out-Of-Control as a Theme in Political Thought. Cambridge: M.I.T. Press, 1977.

Withers, Alexander Scott. Chronicles of Border Warfare. Cincinnati, Ohio: The Robert Clark Company, 1895.

Zembala, Dennis M. Historic American Engineering Record Grafton Machine Shop and Foundry Report. United States Park Service, 1975.

. Northwestern Virginia Railroad, Grafton Bridge Report. United States Park Service, 1975.

Zinn, Melba Pender. Taylor County in Profile. Volume 1, Marriage Register Number "0". Grafton W.Va.: The Taylor County Historical and Genealogical Society, Inc., 1986.

\section{Periodicals}

Appleby, Joyce. "Commercial Farming and the 'Agrarian Myth' in the Early Republic." The Journal of American History. Volume 68, March 1982: 833-49.

"The Baltimore and Ohio Railroad.-The Tunnel." American Railway Times. Volume 2, 20 June 1850: 2.

“Benefits of Railroads.” American Railway Times. Volume 2, 5 December 1850: 1.

Breen, T.H. "An Empire of Goods: The Anglicanization of Colonial America, 1690-1776." Journal of British Studies. Volume 25, October 1986: 467-99.

Brinkman, Charles. "Early History of Grafton.” The Grafton Sentinel. 1929. . "The History of Taylor County." The Grafton Sentinel. 1939-1942. 
Clark, Christopher. "Rural America and the Transition to Capitalism." Journal of the Early Republic. Volume 16, Summer 1996: 223-36.

Clark, Joseph S. "The Railroad Struggle for Pittsburgh: Forty-Three Years of PhiladelphiaBaltimore Rivalry, 1838-1871." The Pennsylvania Magazine of History and Biography. Volume 48, 1924: 1-35.

Evans, Francis T. "Roads, Railways, and Canals: Technical Choices in 19th-Century Britain." Technology and Culture. Volume 22, January 1981: 1-34.

Henretta, James A. "Families and Farms: Mentalité in Pre-Industrial America." The William and Mary Quarterly. Series 3, volume 35, 1978: 3-32.

Howland, Edward. “A Railroad Study.” Harper's New Monthly Magazine. September, 1877: 614-22.

“Influence of Railroads on Agriculture." American Railway Times. Volume 2, 13 June 1850: 1.

Kulikoff, Allan. "The Transition to Capitalism in Rural America." William and Mary Quarterly. Volume 46, January 1989: 120-44.

Pudup, Mary Beth. "The boundaries of class in preindustrial Appalachia." Journal of Historical Geography. Volume 15, April 1989: 139-62.

Salstrom, Paul. "Subsistence-Barter-and-Borrow Systems: An Approach to West Virginia's Economic History." West Virginia History. Volume 51, 1992: 45-53.

Strother, David Hunter. “Artists' Excursion Over the Baltimore \& Ohio Rail Road." Harper's New Monthly Magazine. Volume 19, June 1859: 1-19.

Vickers, Daniel. "Competency and Competition: Economic Culture in Early America." The William and Mary Quarterly. Series 3, volume 47, January 1990: 3-28.

\section{Unpublished Manuscripts}

Barnes, L. Diane. "Avenues to a Market Economy: Harrison County, West Virginia, to 1860." Morgantown, W. Va.: West Virginia University master’s thesis, 1995.

Boughter, I.F. "Internal Improvements in Northwestern Virginia: A Study of State Policy Prior to the Civil War." Pittsburgh, Pennsylvania: University of Pittsburgh Ph.D. dissertation, 1930. 
Cook, James H. "The Secession Crisis in Harrison County, West Virginia." Morgantown, W. Va.: West Virginia University master's thesis, 1993.

Fleming, John K. "Western Virginia as Seen by Foreign Travelers, 1789-1860." Morgantown, W. Va.: West Virginia University master's thesis, 1960.

Hiner, Mary. "The Scotch-Irish and Academies in the Transalleghany Frontier." Morgantown, W. Va.: West Virginia University master's thesis, 1933.

Hunter, Robert F. “The Turnpike Movement in Virginia, 1816-1860.” New York: Columbia University Ph.D. dissertation, 1957.

Leonard, Robert C. "The Rivalry Between the Pennsylvania and the Baltimore and Ohio Railroads Through the Civil War." Morgantown, W. Va.: West Virginia University master's thesis, 1959.

Roberts, Ernest Edward. “Indian Relations From 1783-1796.” Morgantown, W. Va.: West Virginia University master's thesis, 1934. 
APPENDIX 


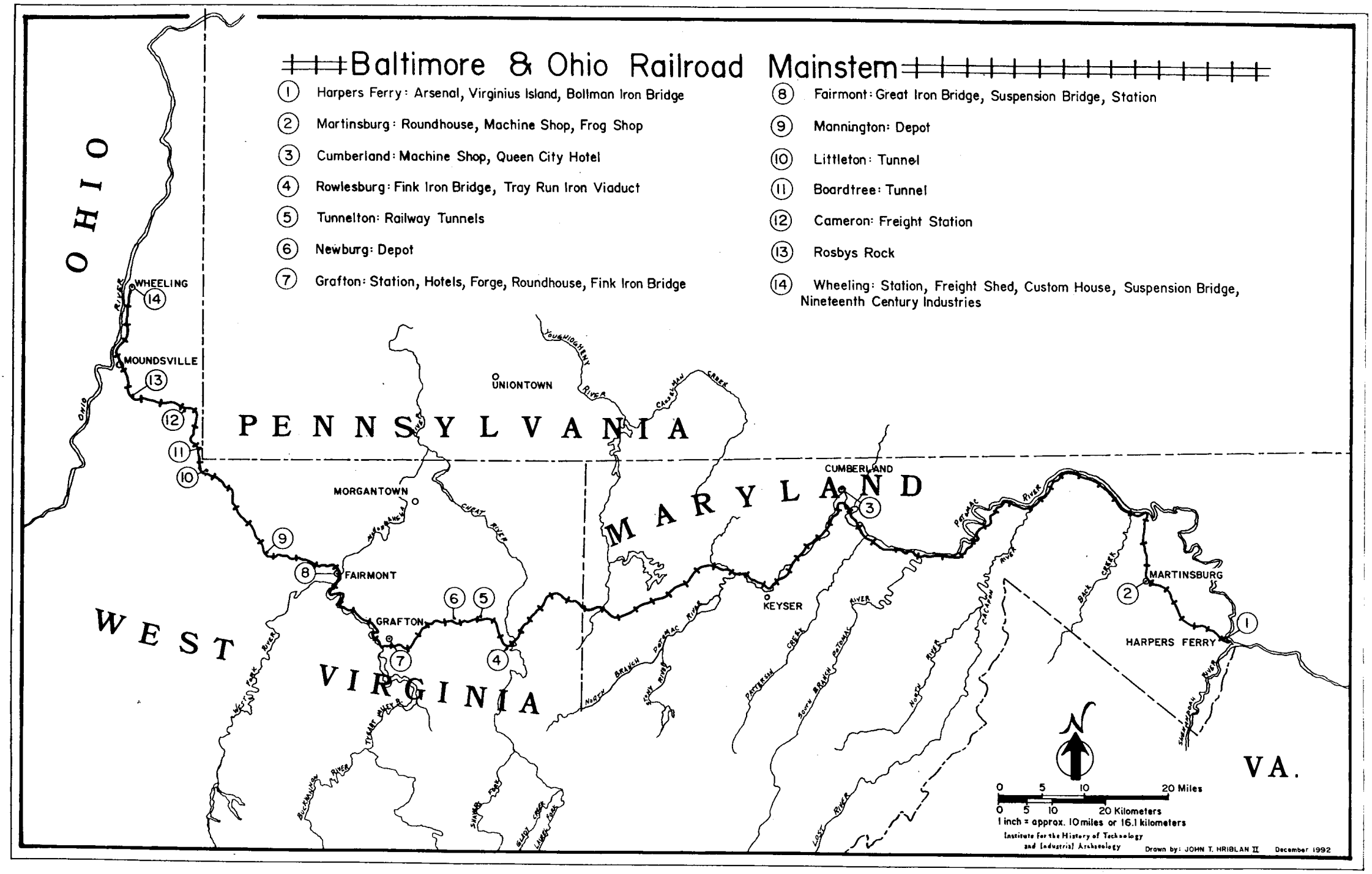




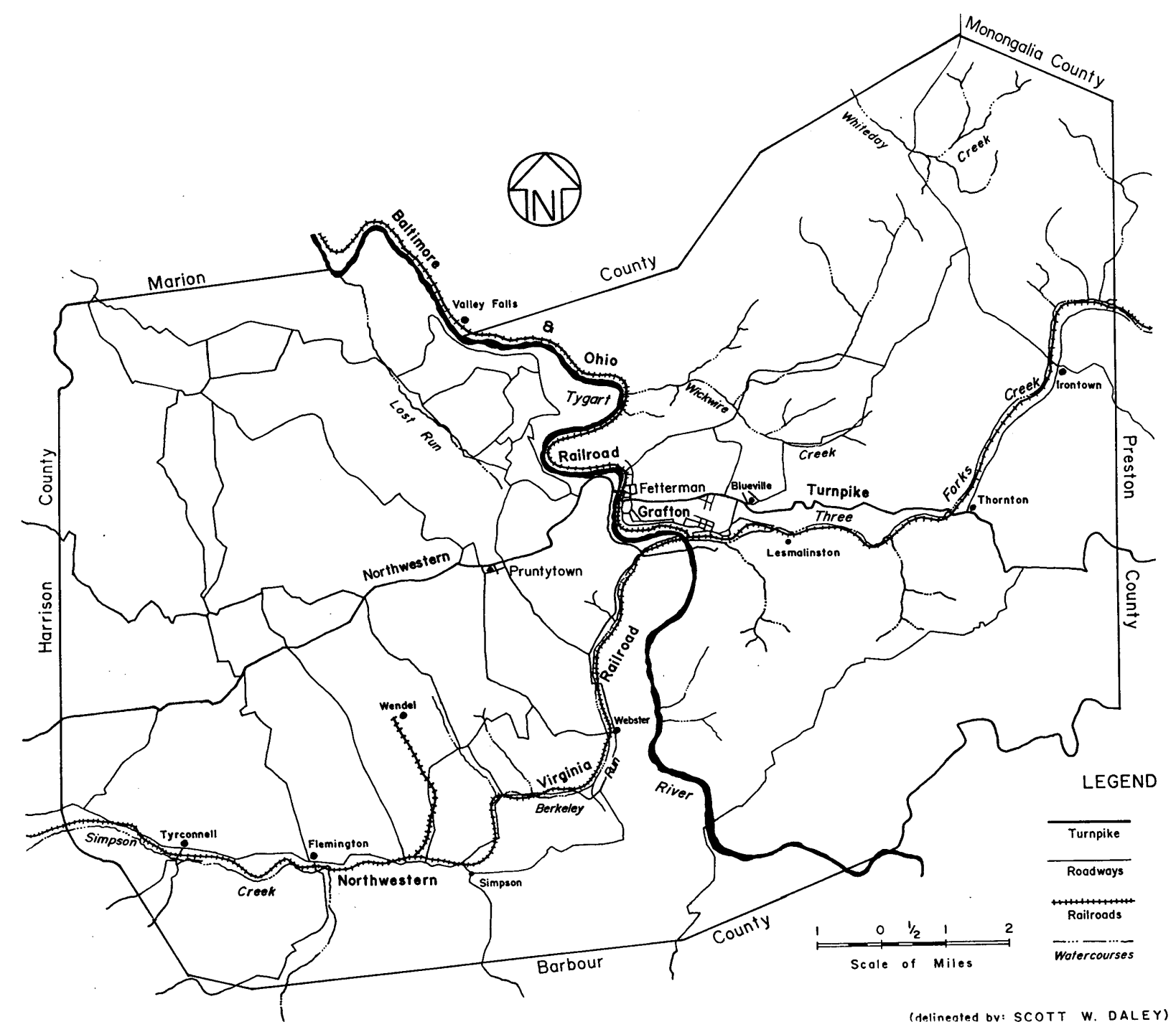

Taylor County, Virginia, circa 1860. 


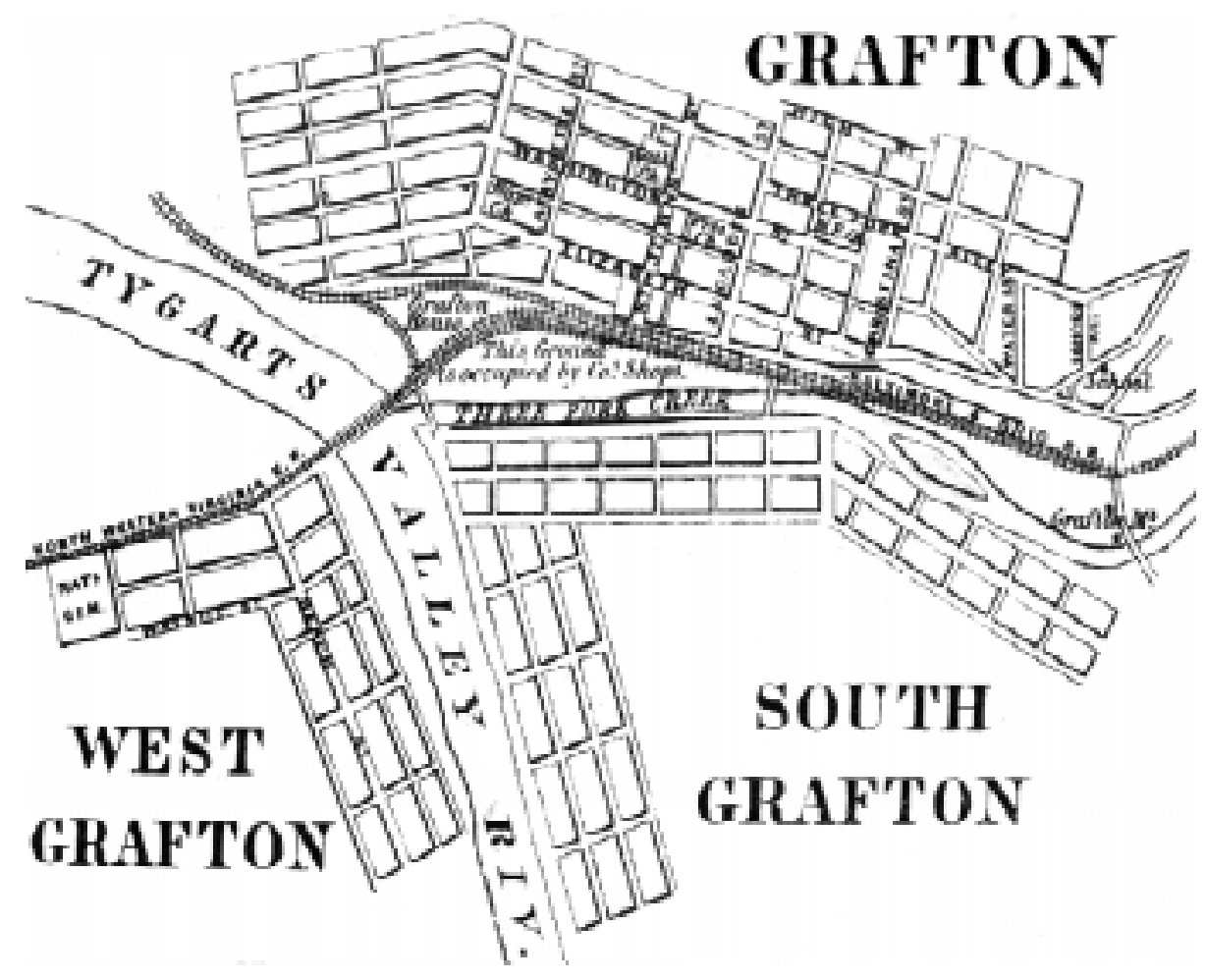

City of Grafton in 1872, two decades after construction of the Baltimore \& Ohio Railroad, although here the Parkersburg Branch is still labeled as the Northwestern Virginia Railroad, despite its takeover by the $\mathrm{B} \& \mathrm{O}$ in 1860 . B\&O shops and service facilities are labeled in the center. "Grafton House" at the rail junction is the Grafton Hotel. West and South Grafton were separate incorporated towns until after Grafton became Taylor county seat in 1878. Like Fetterman, terrain dictated Grafton's unusual layout between steep hills and two watercourses. (Map from White's New County and District Atlas of the State of West Virginia, 1873) 


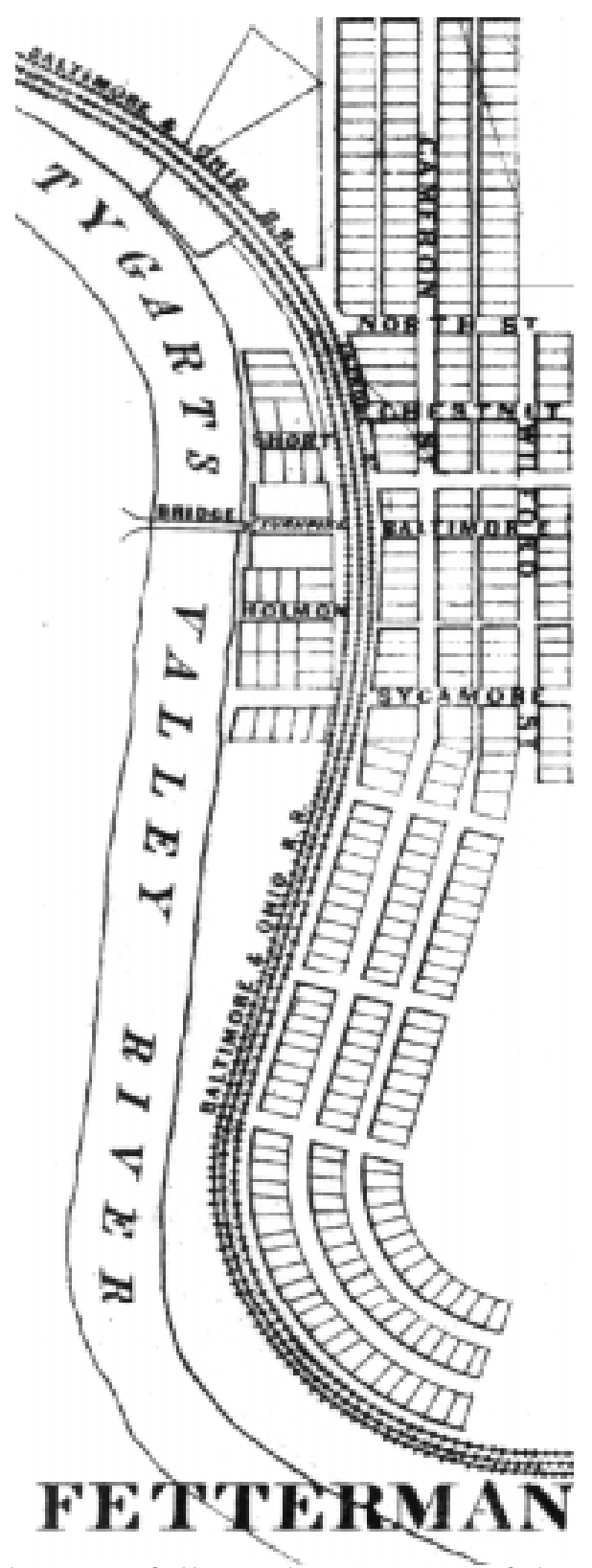

Fetterman as seen in 1872. The town follows the contours of the river, with hills on the opposite side. City lots have already been platted, although most were not occupied. Baltimore \& Ohio Railroad facilities lay at the north end of town between the tracks and city lots. At times of low water, turnpike traffic could ford the river at the end of Baltimore Street when the bridge was under repair. The turnpike bridge and B\&O Main Stem drew fighting in 1861 as the Civil War began. (Map from White's New County and District Atlas of the State of West Virginia, 1873.) 


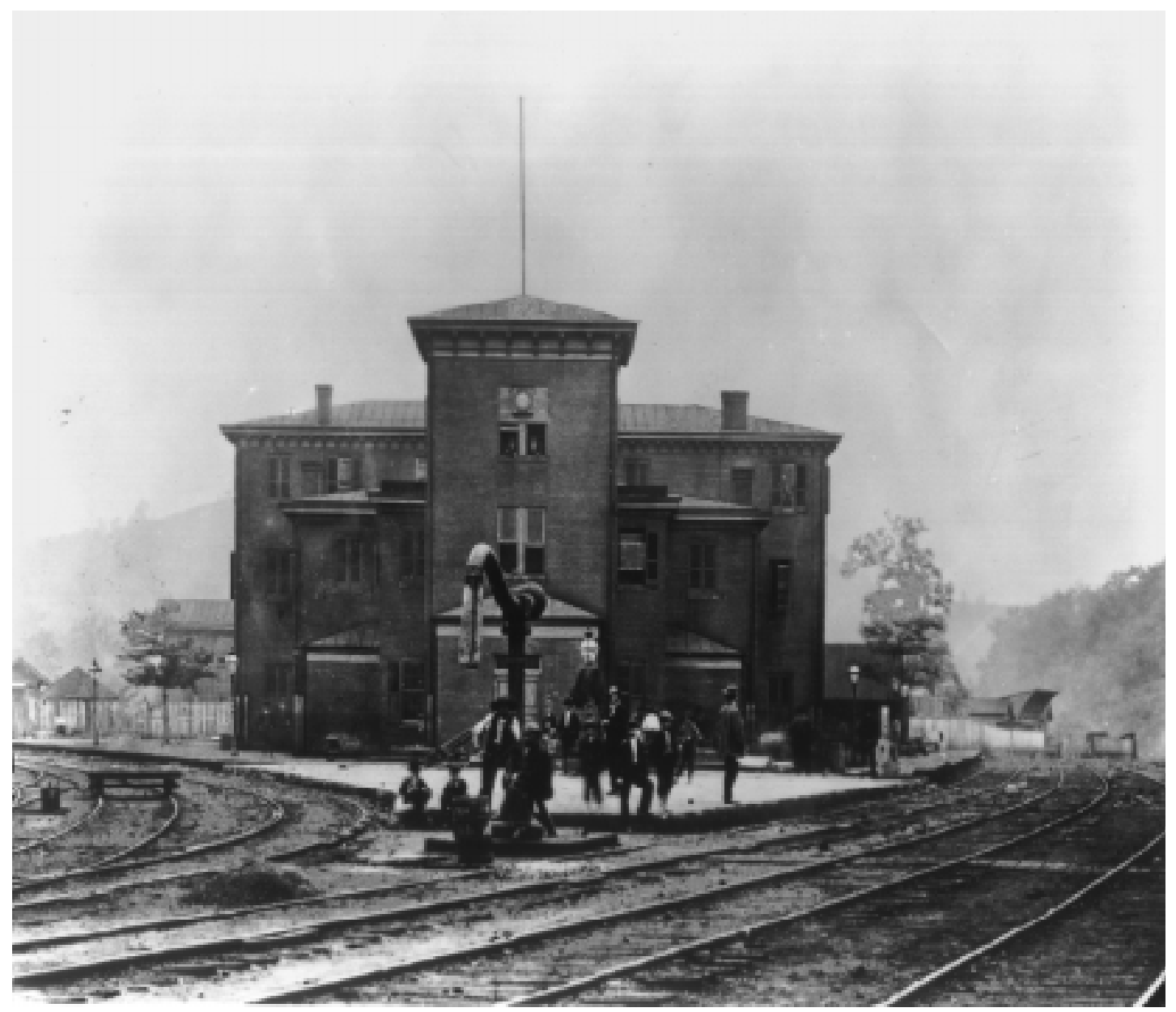

View of the Grafton Hotel taken by an unknown B\&O Company photographer, circa 1858 , looking west. B\&O workers followed the Italianate style in constructing the building. To the right are the B\&O Main Stem tracks leading to Wheeling. To the left is the Northwestern Virginia Railroad, or the line called the Parkersburg Branch by Baltimore \& Ohio Railroad officials. This view shows the stone platform built by Henry Leuthke and his workers. The tall object in the center foreground is called a penstock, or an apparatus to deliver water to steam locomotives. (Courtesy of The B\&O Railroad Museum, Inc.) 


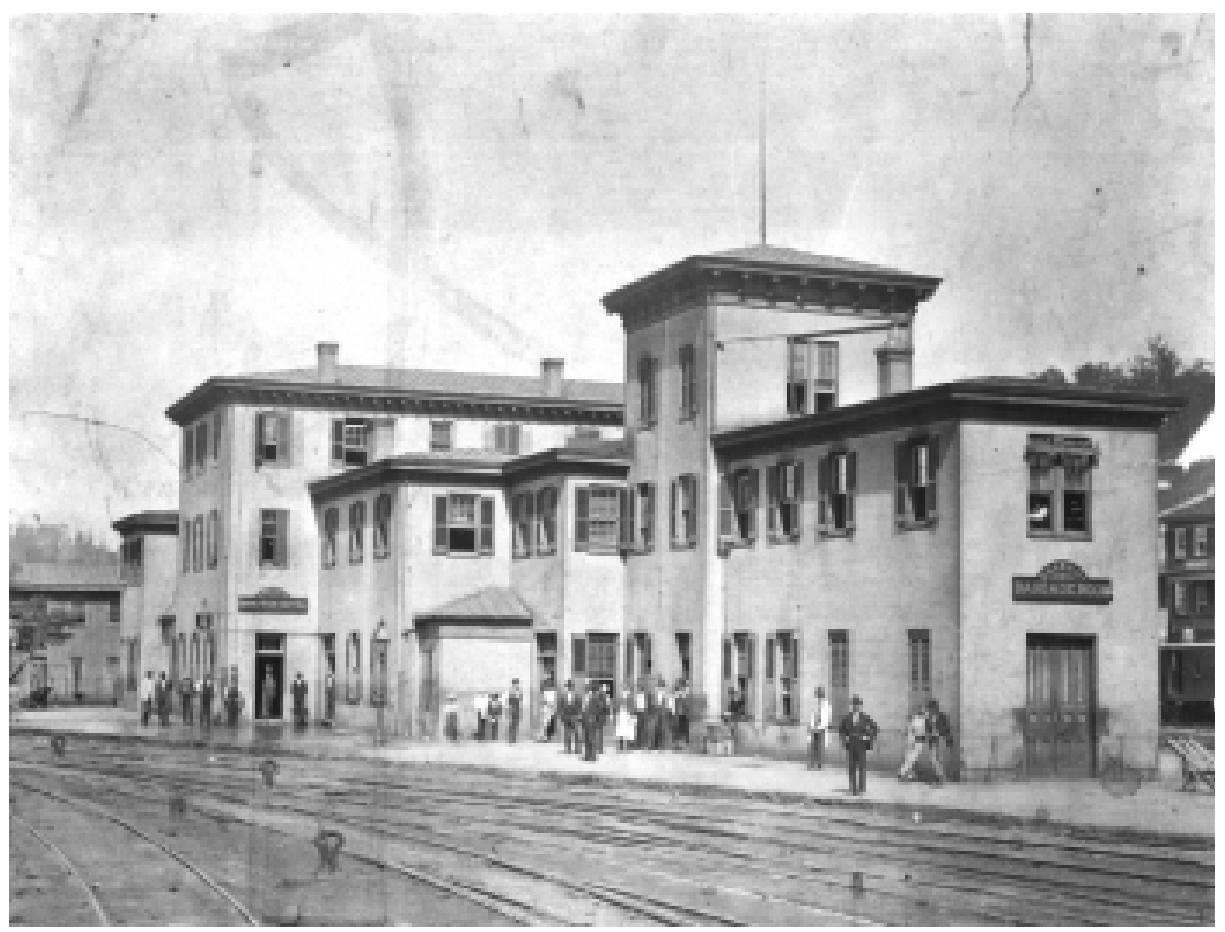

Post-Civil War view of the Grafton Hotel taken by a B\&O Company photographer circa 1875, looking northwest. The Parkersburg Branch and west end yard tracks are in the foreground. A new extension had been added to the east end of the building for baggage and freight by this time, with a telegrapher's office on the second floor. In addition, the entire building was whitewashed, and the clock was removed from the third floor window. It is not clear that the railing built along the new addition was meant to prevent baggage carts from damaging the walls or to provide momentary relaxation for weary patrons. (Courtesy of the B\&O Railroad Museum, Inc.) 


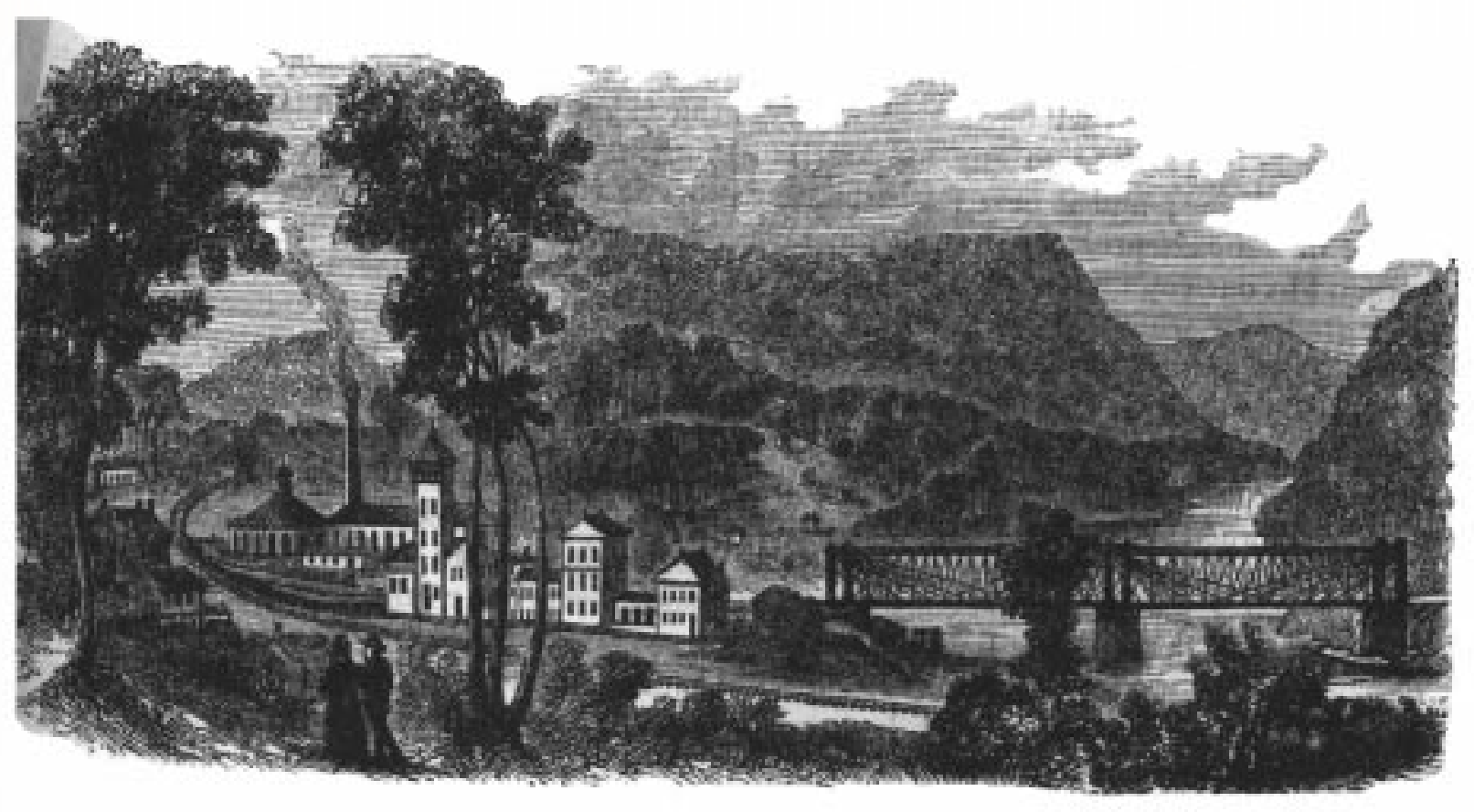

Grafton as seen circa 1857 looking southeast. The Baltimore to Wheeling main stem can be seen in the foreground. At far right is the Northwestern Virginia Railroad iron bridge over the Tygart River, designed by Baltimore \& Ohio Railroad engineer Albert Fink. Left of the bridge is the Grafton Hotel, passenger station, and freight depot. The building with the tall smokestack is the Grafton machinery and maintenance shop complex, and the locomotive roundhouse is to the left. At far left, north of the $\mathrm{B} \& \mathrm{O}$ main stem, are the earliest homes and businesses in Grafton. (Line drawing from Harper's New Monthly Magazine 14 (June 1857): 609.) 